\title{
Assessment of Zero Gravity Effects on Space Worker Health and Safety
}

November 1980

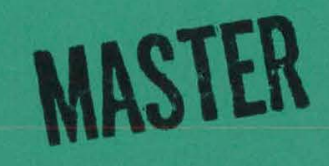

Prepared for:

U.S. Department of Energy

Office of Energy Research

Solar Power Satellite Project Division

Under Inter-Agency Agreement AI02-79CH10025

\section{DOE/NASA}

Satellite Power System

Concept Development and

Evaluation Program 


\section{DISCLAIMER}

This report was prepared as an account of work sponsored by an agency of the United States Government. Neither the United States Government nor any agency Thereof, nor any of their employees, makes any warranty, express or implied, or assumes any legal liability or responsibility for the accuracy, completeness, or usefulness of any information, apparatus, product, or process disclosed, or represents that its use would not infringe privately owned rights. Reference herein to any specific commercial product, process, or service by trade name, trademark, manufacturer, or otherwise does not necessarily constitute or imply its endorsement, recommendation, or favoring by the United States Government or any agency thereof. The views and opinions of authors expressed herein do not necessarily state or reflect those of the United States Government or any agency thereof. 


\section{DISCLAIMER}

Portions of this document may be illegible in electronic image products. Images are produced from the best available original document. 


\section{NOTICE}

This report was prepared as an account of work sponsored by the United States Government. Neither the United States nor the United States Department of Energy, nor any of their employees, makes any warranty, express or implied, or assumes any legal liability or responsibility for the accuracy, completeness, or usefulness of any information, apparatus, product, or process disclosed, or represents that its use would not infringe privately owned rights. Reference herein to any specific commercial product, process, or service by trade name, mark, manufacturer, or otherwise, does not necessarily constitute or imply its endorsement, recommendation, or favoring by the United States Government or any agency thereof. The views and opinions of authors expressed herein do not necessarily state or reflect those of the United States Government or any agency thereof.

Avallable from:

National Technical Information Service (NTIS)

U.S. Department of Commerce

Springfield, Virginia 22161

Price: Printed Copy: $\$ 10.00$

Microfiche: $\quad \$ 4.00$ 


\section{master}

DOE/ER-10025-T1

Dist. Category UC-41

\section{Assessment of Zero Gravity Effects on Space Worker Health and Safety}

November 1980

Prepared by:

NASA Johnson Space Center

Houston, Texas 77058

under Inter-Agency Agreement Al02-79CH10025

Prepared for:

U.S. Department of Energy

Office of Energy Research

Solar Power Satellite Project Division

Washington, D.C. 20585

\section{DOE/NASA}

Satellite Power System

Concept Development

and

Evaluation Program

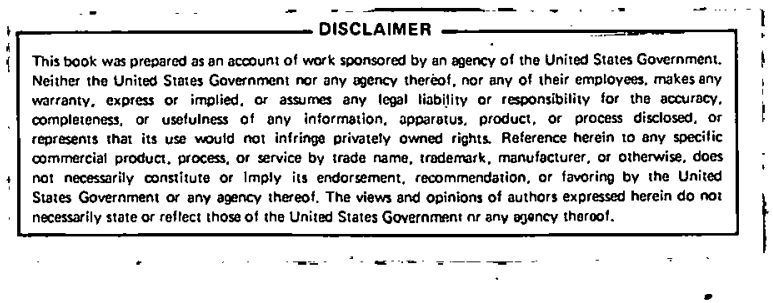


A. Objective..................................

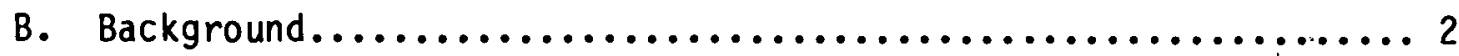

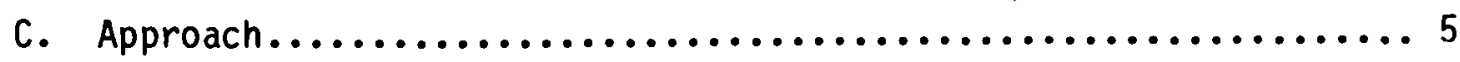

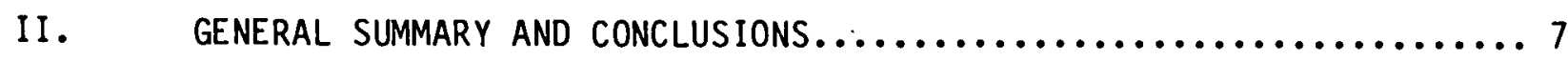

III. INVENTORY OF HUMAN RESPONSES TO SPACE FLIGHT ...............10

A. Muscloskeletal System........................... 11

B. Cardiovascul ar system............................ 14

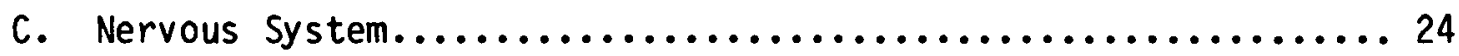

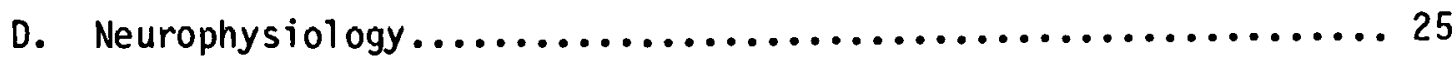

E. Excretory System.............................. 27

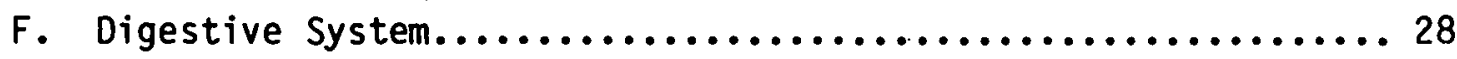

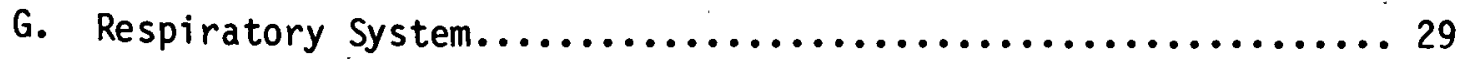

H. Reproductive System............................ 30

I. Biochemistry ................................. 31

J. Endocrine System.............................. 38

K. Energy Metabolism.............................. 42

L. Fluid Shifts................................. 43

M. Integumentary System......................... 44

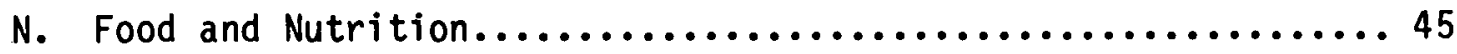

0. Electrolyte Balance............................ 46

IV. DISCUSSION OF HUMAN RESPONSES TO SPACE FLIGHT............. 47

A. Weightlessness $\ldots \ldots \ldots \ldots \ldots \ldots \ldots \ldots \ldots \ldots \ldots \ldots \ldots \ldots \ldots \ldots \ldots$

B. Effects of Acceleration/Deceleration.................. 71

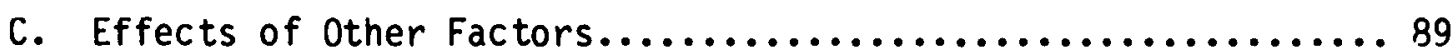


v. AMELIORATION OF POTENT IALLY ADVERSE EFFECTS............... 92

A. Preventive Actions.............................. 92

B. Treatment and Curative Actions...................... 97

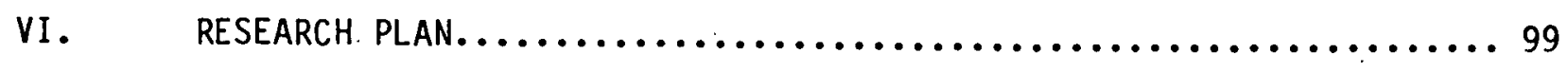

A. General........................................ 99

B. Research Areas....................................

C. Schedule.......................................101

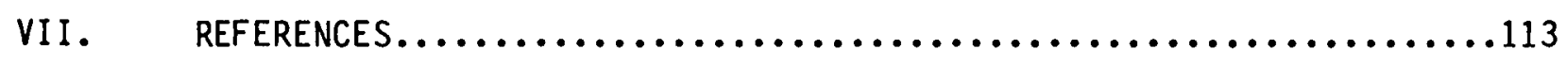

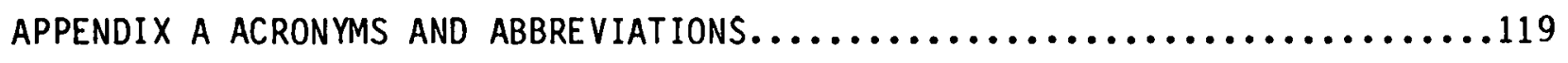




\section{LIST OF FIGURES}

Figure

Page

I-1 Factors involved in comparing past and future missions......... 3

I-2 Major differences in program requirements relating to the space workers vs. astronaut crews .......................... 4

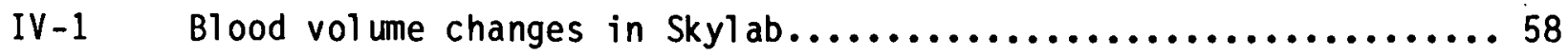

IV-2 Adaptive fluid and electrolyte response to weightlessness

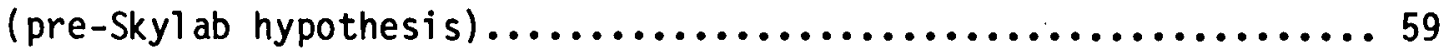

IV-3 AGARD physiological acceleration system................... 74

IV-4 Influence of $+G_{x}$ accelerative stress on intraperitoneal pressure.. 77

IV -5 Basic mechanisms of accelerative action on an organism.........78

IV-6 Comparision of average $G$ tolerance in four vectors of sustained

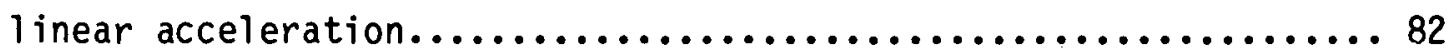

IV -7 Effect of body position on tolerance to acceleration..........83

IV-8 Voluntary endurance of acceleration by highly motivated test pilots

IV-9 Acceleration profile of launch phase of the manned Mercury-Atlat

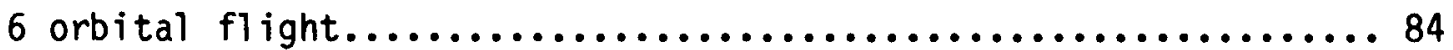

IV-10 Acceleration profiles of the Space Shuttle vehicle as a function

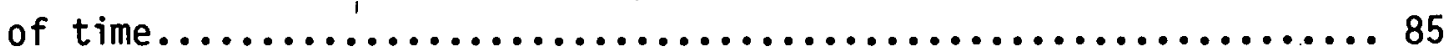

VI-1 Comparative schedules for the Shuttle/Spacelab, SOC, and SPS programs

\section{LIST OF TABLES}

Table Page

IV-1 SUBJECTIVE EFFECTS OF ACCELERATION................... 79

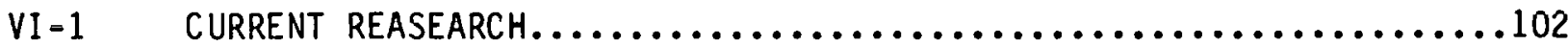

VI-2 TYPICAL RTOP: 199-20-31 Bone/Muscle Alterations...............103

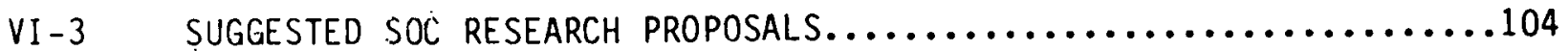


I. INTRODUCTION

This report has been prepared in response to a letter request from Margaret $R$. White of the Lawrence Berkeley Laboratory dated March 5, 1979 and an interagency agreement DOE IA \#DE-A102-79CH10025 between the National Aeronautics and Space Administration (NASA) - Lyndon B. Johnson Space Center (JSC) and the U.S. Department of Energy (DOE). The report presents the results of a study performed by personnel within the NASA - JSC Life Sciences organization in conjunction with elements of The Boeing Company. In preparing this report, an effort has been made to respond to the letter and intent of the Statement of Work (SOW) included in the interagency agreement.

\section{A. OBJECTIVES}

One objective of the study is to assess the effects of all curently known deviations from normal of medical, physiological and biochemical parameters which appear to be due to zero gravity (zero-g) environment ${ }^{1}$ and to acceleration and deceleration to be experienced, as outlined in the reference SPS design, by space workers. Study results are based on current knowledge and the current SPS Reference System Report, DOE/ER-0023, October 1978. These results include:

a. Indentification of possible heal th or safety effects on space workers - either immediate or delayed - due to the zero gravity environment and to acceleration and deceleration,

b. Estimation of the probability that an individual will be adversely affected.

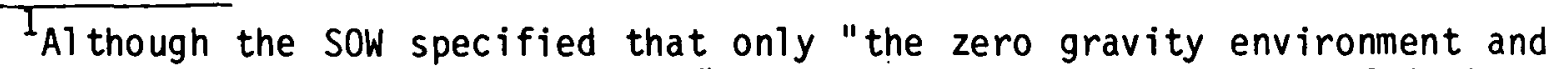
accelerations will be considered", NASA has taken the 1iberty of including potentially adverse effects/affects caused by other stresses of working in the space environment. This was done to provide relevant information which might otherwise have been excluded from consideration. 
c. Description of the possible consequence to work efficiently in persons adversely affected, and

d. Description of the possible/probable consequences to immediate and future heal th of individuals exposed to this environment.

Another objective of this study is to prepare a research $\mathrm{plan}$ which addresses the uncertainties in current knowledge regarding the heal th and safety hazards to exposed SPS space workers. The $\mathrm{plan}$ is presented in section VI, Research Planning. It identifies current on-going research, proposed research to support a Space Operations Center (SOC) program, and research that will be recommended specifically to support an SPS program.

\section{B. BACKGROUND}

NASA has drawn heavily on the biomedical results from the Apollo and Skylab missions, and the Apollo-Soyuz Test Project (ASTP). Current knowiedge of the effects of weightlessness and acceleration/deceleration is updated. Where appropriate, we have used the biomedical results of all prior manned missions flown by the United States as well as the groundbased experimentation done in conjunction with these flight programs. Information from Soviet Union space studies has been used where possible but is limited by credible sources of documentation containing sufficient supporting data.

Significant information used as a base is summarized in section IV and is included in matrix form in section III.

It is recognized that the sources of current knowledge are from prior programs that subjected cremmembers to situations and conditions not fully representative of the situations and conditions that future SPS space workers might encounter. To formulate their predictions of hazards, NASA and Boeing personnel assigned to this study have imade a delermined effort to identify and define the nature and magnitude of these differences. Factors involved in comparing past and future missions are shown in figure I-1. Some of the major differences in program requirements relating to the SPS space workers vs. the astronaut crews are shown in figure I-2. 


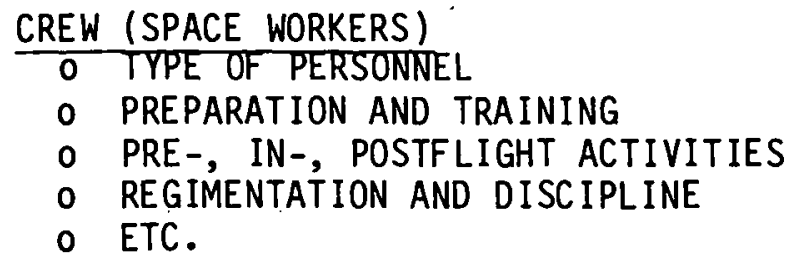

MISSION FLIGHT PARAMETERS

$\begin{array}{ll}0 & \text { ORBITS } \\ 0 & \text { ACCELERATIONS } \\ 0 & \text { SOLAR ACTIVITY PERIODS } \\ 0 & \text { ETC. }\end{array}$

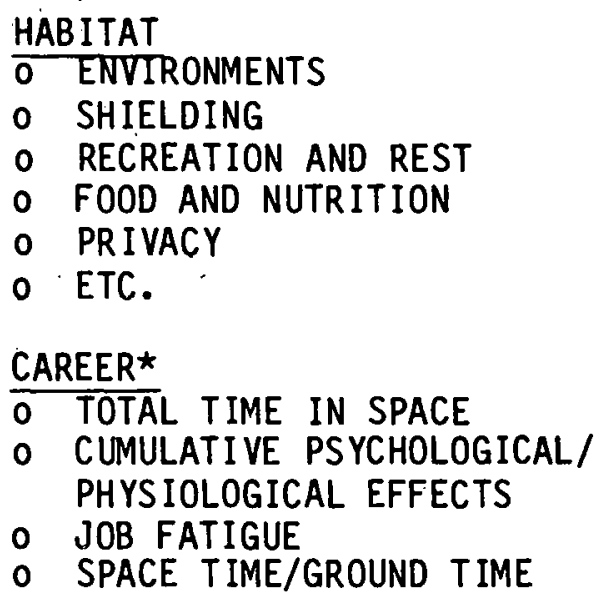

*NOTES: DURING A 5-YEAR CAREER WITH A 90 DAY UP/90 DAY DOWN, A PÉRSON MAY SUFFER FROM SPACE ENVIRONMENT EFFECTS FOR 4 TO 5 MONTHS OUT OF EACH 6 MONTHS, RESULTING IN A CAREER SITUATION OF BEING IN A DEVIATE PHYSICAL CONDITION FOR $31 / 2$ TO 4 YEARS TO THE 5 YEAR TOTAL:

AFTER THE 84 DAY SKYLAB MISSION, TWO CREWMEN HAD NOT REGAINED HEEL BONE CALCIUM BY DAY 95 POSTFLIGHT.

FIGURE I-1 Factors involved in comparing past and future missions. 
1. THE TYPE OF PERSONNEL SELECTED:
SPACE WORKERS
- MALE-FEMALE
- BROAD AGE RANGE
VS. $\quad 0$ SKYLAB ASTR MALE
VS. $\quad 0$ LIMITED RANGE
- PHYSICALLY SCREENED AND DEVELOPED
- PHYSICALLY BASICALLY UNSCREENED VS.
- LARGE CREWS
VS. $\quad$ 3-MAN CREW

2. THE EXTENT AND TYPE OF CREW PREPARATION FOR SPACE DUTIES:

\section{SPACE WORKERS}

- SHORTER PREPARATION TIME AND TRAINING, LIMITED PR IMARILY TO JOB RELATED ACTIVITY, WITH MINIMUM SPACECRAFT PHYSICS \& SYSTEMS, HAB ITAB ILITY, ETC.
SKYLAB ASTRONAIJTS

- SEVERAL YEARS DF BROADBASED EDUCATION AND TRAINING IN ALL ASPECTS OF MISSION AC.TIVITIES WITH EXTENSIVE EDUCATION IN FUNDAMENTAL.S OF ALL SC IENCES INVOLVED IN PROGRAM.

3. THE NATURE OF THE MISSION ACTIVITY ASSIGNMENTS AND THE FREOIJENCY AND DURATION OF FLIGHT TIME/GROUND TIME: SPACE WORKERS

- VARIETY OF SPEC IALIZED SKILLS (WITH MINIMUM PROFESSIONAL ENGINEERING AND SC IENTIF IC SKILLS). SKYLAB ASTRONAUTS

- EACH CREW MEMBER CAPABLE OF ALL SCIENTIFIC, TECHNICAL AND MANAGEMENT REOUIREMENTS.

- WORK AT PEAK EFF IC ILNCY FOR MAXIMUM SAFE PERIOD DURING MISSION. RETURN TO SPACE IN SHORTEST SAFE AND PRACTICAL IIME.

n WORK AT HIGHLY MOTIVATING JOBS AT CAREEFULLY SCHEDULED TIME LINES BASED ON METABOLIC AND EXPERIMENT REOUIREMENTS. MISSION DURATION RASFI ON CREWS' CONDITION (CÁREFULLY MUNITORED). RETURN TO SPACE NOT A PRESSING ITEM.

Figure 1-2 Major differences in program requirements relating to the space workers vs. astronaut crews. 


\section{APPROACH}

The approach used by NASA in performing this study was to assign qualified and experienced scientists in various life sciences disciplines to identify and define the possible environmental effects on SPS space workers. The NASA participants worked closely with an aerospace contractor (The Boeing Company) who was responsible for coordination, compilation, collation and documentation of the information provided. NASA and Boeing participants drew extensively from documented research experiences and available expertise of prior manned space flight programs.

Sources of information includes:

- Documented biomedical results from Skylab and other manned space missions. (Limited Soviet data were included from credible sources containing sufficient supporting data).

- Documented results form ground-based biomedical research.

- Documented results from ground-based tested and verified design and operational approaches.

- Documented information from other programs involving isolated crew habitation and confined quarters, i.e., Arctic and Antarctic activ1ties, off-shore oil operations, undersea programs (Tektite), submarine duty, ctc.

- Direct contact with designated NASA or contractor expert consultants.

- Feedback from review meetings and comments on submitted reports.

The data base from these sources is comprehensive and includes:

- Results from three major manned space flight programs of the United States. They are: seven Apollo flights, three Skylab missions and the Apo.110-Soyuz project. 
- Results from extensive ground-based and flight research in all human body systems. (The subjects were predominantly male.)

- Experiences gained from development of systems designed to support space flight. These systems are for health care, life support and protection, and environment and biological monitoring.

- Results from extensive ground-based development and demonstration testing. 
II. GENERAL SUMMARY AND CONCLUSIONS

Answers sought for the following critical questions, before commitment to build and operate an SPS are: How long can humans live safely and work efficiently in space? What is the maximum duration of an effective work schedule? What are the total number and frequency of missions to plan as a career in either low earth orbit (LEO) or geosynchronous earth orbit GEO?

To answer these and other questions for the Apollo program, NASA investigated the capability of astronauts to cope safely with the stresses associated with performing a vast battery of flight related tasks. During the Mercury and Gemini missions, we learned that man could withstand 1 aunch and reentry stresses, could perform complex mental and physical tasks for periods of up to 14 days, and could readapt to Earth gravity. without adversely altering normal body functions. During Apollo missions, knowledge and confidence in man's ability to safely and effectively perform complex tasks in the lunar and space environments and readily adapt to changing environments was further expanded. During Skylab, emphasis was directed to man's ability to live and work in space by performing medical-oriented research experiments and by monitoring the inflight operation of several major body systems. In addition, dedicated research medical equipment was tested extensively.

The inflight experiments, designed to contribute to understanding the functioning of major body systems, included the cardiovascular musculoskeletal, hematologic, vestibular, metabolic, neurologic and endocrine systems. It was shown that a few body systems were not affected, the majority showed adaptive chariges, and there were indications of progressive changes (e.g., bone demineralization, muscular atrophy, plasma volume and red blood cell loss.) These changes contraindicated long-term exposure to zero-g forces unless corrected.

In Skylab, major emphasis was directed to evaluating on-board life support systems. These included food, waste management, personal hygiene and inflight medical support. This data base will be valuable in planning future longduration missions. 
Evaluation of the medical experiments and the operational medical systems of the 84-day manned Skylab III mission provided a high degree of confidence in man's ability to work and live safely in a space environment for periods which may exceed 120 days.

Al though most adverse affects experienced during space flight soon disappeared upon return to the Earth's environment, there remains a definite concern for the long-term effects to SPS space workers who might spend as much as half their time in space during a possible five-year career period. The proposed 90-day up/90-day down cycle, coupled with the fact that most of the effects of weightlessness may persist throughout the flight along with the realization that rccovery may orrupy much of the terrestrial stay, may keep the SPS workers in a deviant physical condition or state of flux for 60 to 100 percent of their five-year career. Further studies in effects/affects of sequential adaptation from one-g to zero-g, and reverse, wfll be necessary before a fiveyear career period can be evaluated properly.

The NASA and Boeing scientists involved in this study have concluded that there is substantial evidence to indicate that only preventable and corrective adverse effects will be experienced by SPS space workers. They further believe that, al though additional potentially adverse effects may be identified prior to the early SPS missions, counteracting or ameliorating approaches can be developed contemporaneously to avoid any adverse effects to their heal th and safety.

This position should not be construed as having insufficient concern for the safety and health of the SPS space workers. It is based on the postulation that NASA/DOE will conduct adequate research and development to recognize potential threats and provide countermeasures to protect the workers. It further presumes that workers will be selected, trained, and motivated to make proper use of equipment, and approaches will be designed to make their careers in space heal thy and safe. 
The study did not include the effects of radiation.

There are several aspects of this study that deserve consideration if the conclusions presented are to be maintained in a proper perspective.

1. Conclusions based on "current knowiedge" are derived from prior manned space flights where the type and condition of the crew and the mission conditions exposing the crew to adverse effects of the space environment are in many respects different from those anticipated for future SPS space workers.

2. The final definition of the role that man will play in space and the details of his living and working conditions will evolve during the next 15 to 20 years. We will gain additional experience through development and operations for precursor space projects detailed in the Space Transportation System (STS) and the SOC programs.

3. The NASA Life Sciences and Crew Systems organizations will gain an abundance of test data relating to the physiological and psychological stresses to be experienced by the SPS crews and their families. They are confident that the means to ameliorate or prevent any adverse effects due to these stresses will be developed. The information can be made available to the DOE at appropriated intervals during the developmental phases of the SPS program.

4. Al though certain biomedical problems are known to exist in today's manned missions and cumplications are expected to occur when large numbers of people begin to make a career of working in space, our scientist and technical experts believe that these problems will be resolved and that humans will be able to live and work effectively in space without unusual degradation to their heal th, safety, and general well being. 


\section{INVENTORY OF HUMAN RESPONSES TO SPACE FLIGHT}

This section presents a sumary of known deviations from normal of human body systems in response to the space flight environments. It also includes methods of amelioration and a prognosis of impact on SPS space workers.

An encapsulated Inventory of Human Responses to Space Flight in matrix form, which follows, was derived from the American biomedical research programs in space. The major body systems/research entities in the order in which they appear are listed below. Detailed discussion of each entity starts on paqe 46.
A. Musculoskeletal System
B. Cardiovascular System, including B.1. Hemodynamics, B.2. Hematology, and B.3. Immunology
C. Nervous System
D. Neurophysiology, including D.1. Vestibular, D.2. Special Sense Organs, and D.3. Other Sensors
E. Excretory System
F. Digestive System
G. Respiratory System
H. Reproductive system
I. Biochemistry
J. Endocrine System
K. Energy Metabol ism
L. Fluid Shifts
M. Integumentary System
N. Food and Nutrition
0. Electrolyte Balance 
INVENTORY OF HUMAN RESPONSES TO SPACE FLIGHT

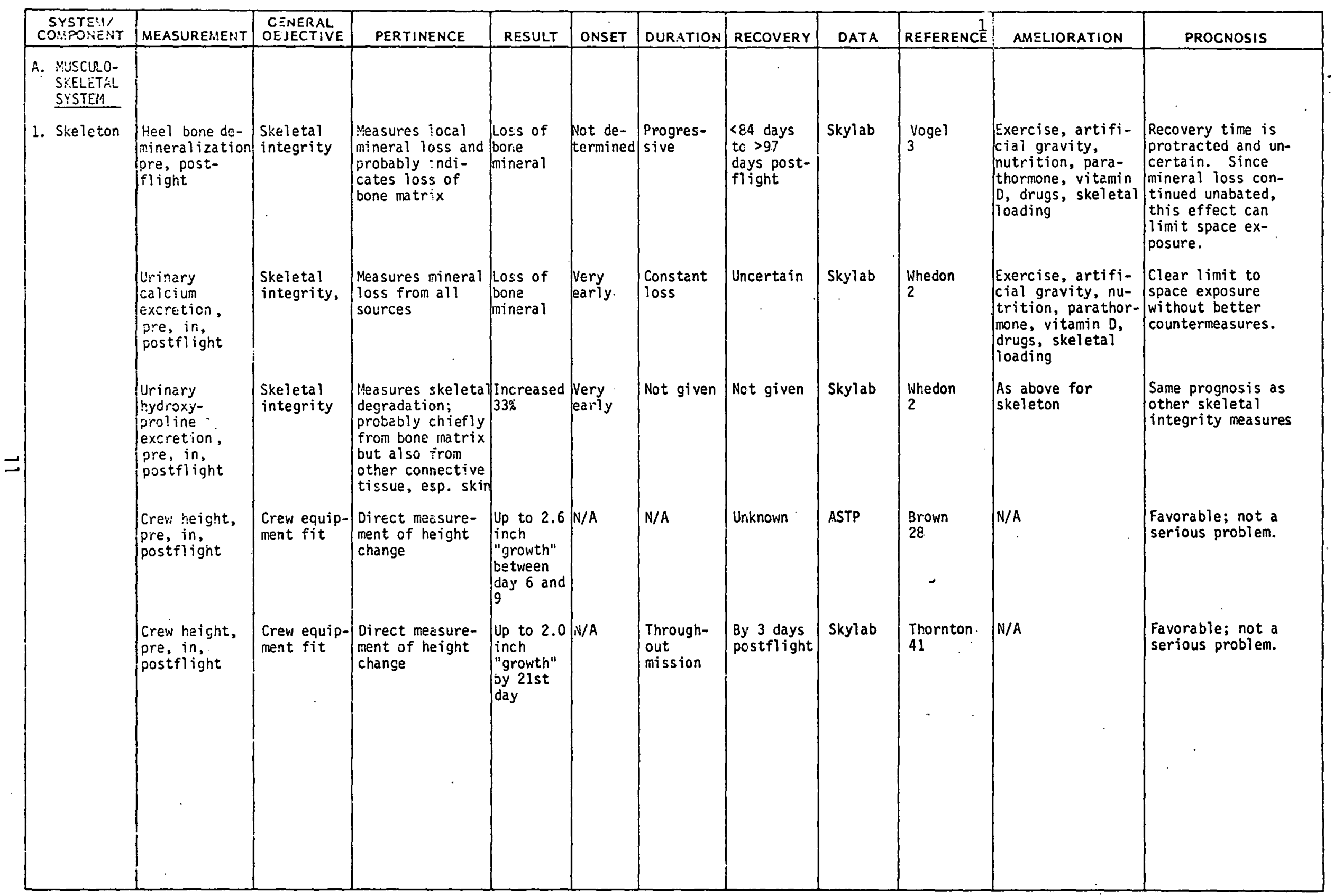

${ }^{1}$ See listing of references beginning on $p . .$. 
INVENTORY OF HUMAN RESPONSES TO SPACE FLIGHT

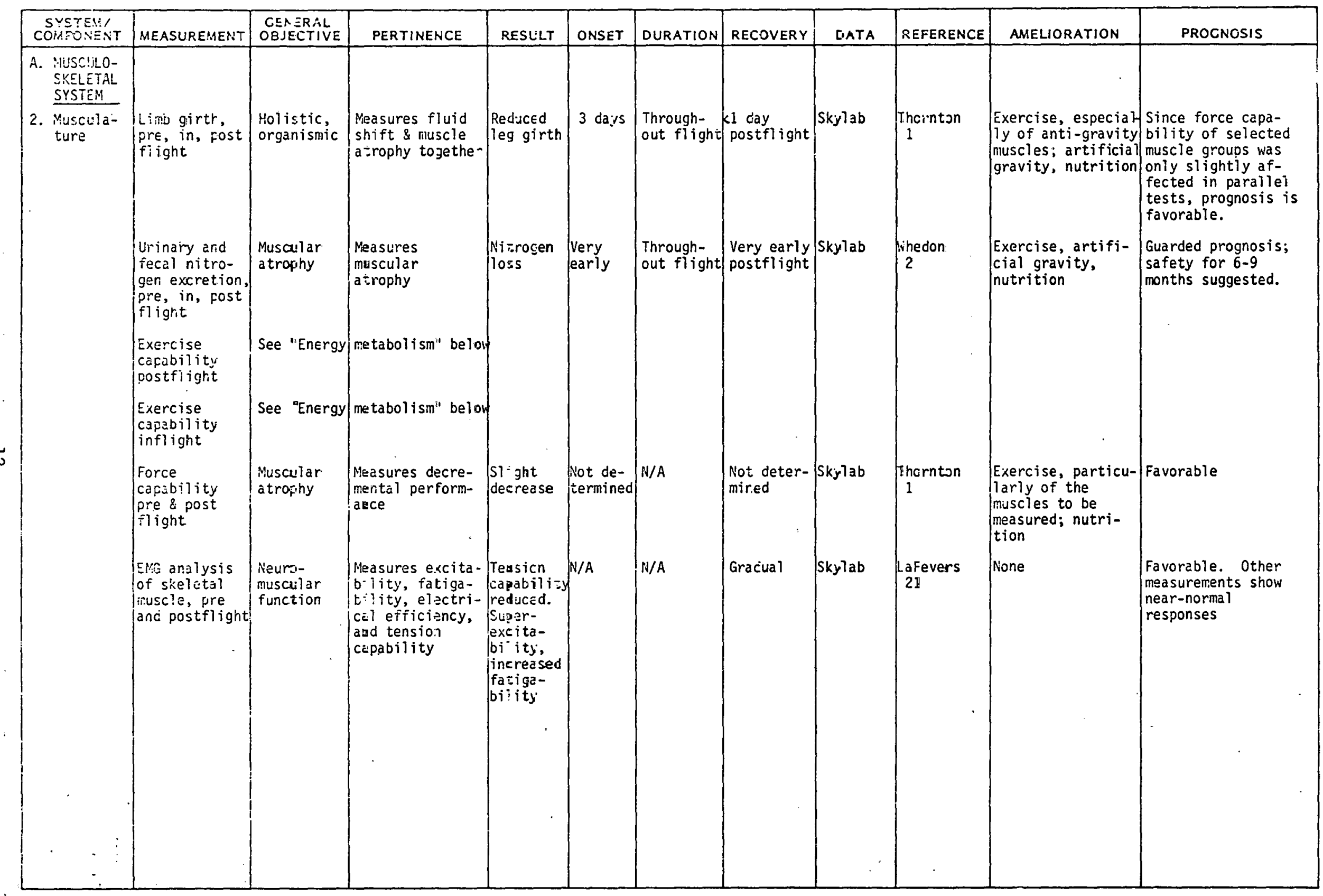

1. 
INVENTORY OF HUMAN RESPONSES TO SPACE FLIGHT

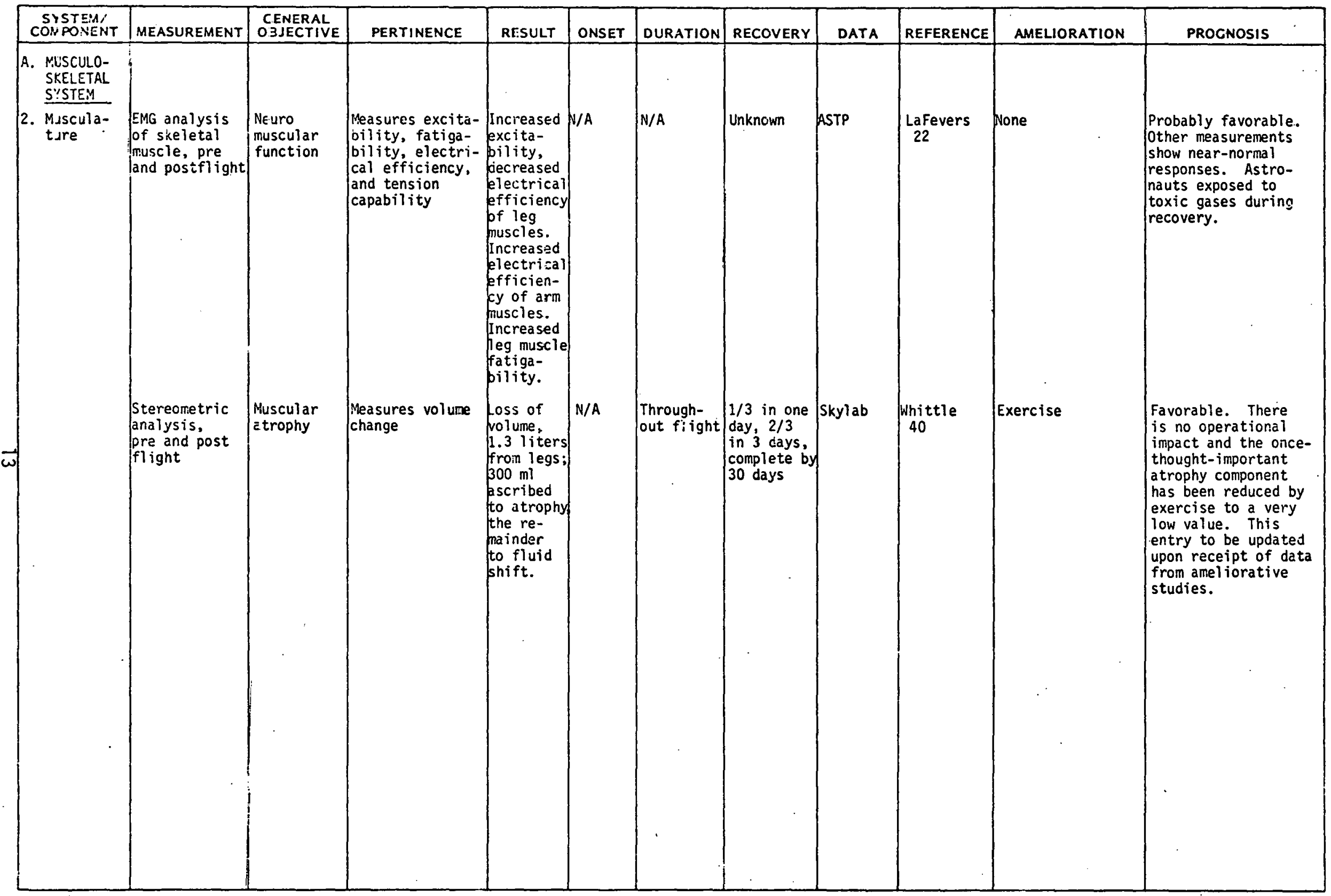


INVENTORY OF HUMAN RESPONSES TO SPACE FLIGHT

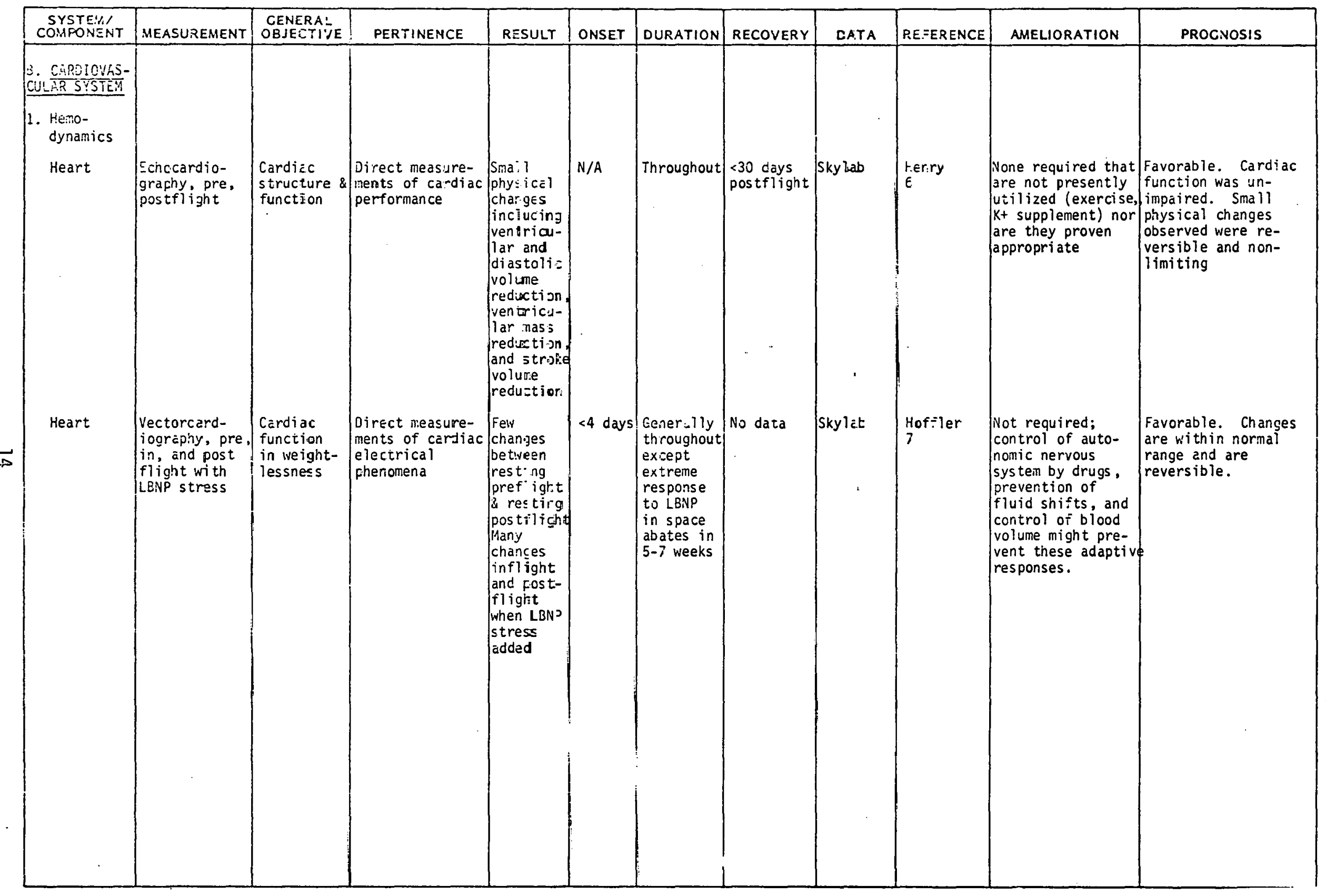


INVENTORY OF HUMAN RESFONSES TO SPACE FLIGHT

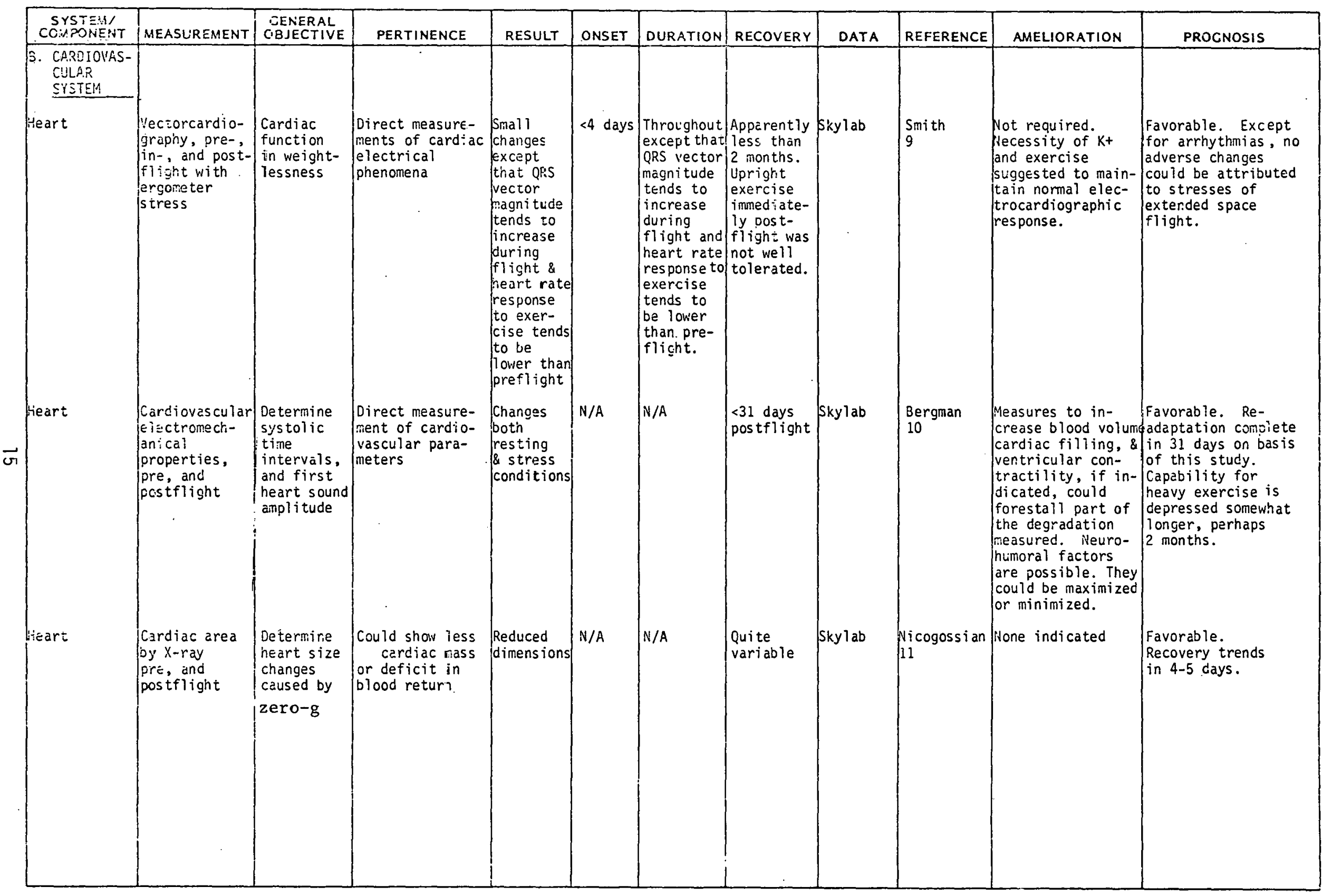


INVENTORY OF HUMAN RESPONSES TO SPACE FLIGHT

\begin{tabular}{|c|c|c|c|c|c|c|c|c|c|c|c|}
\hline $\begin{array}{l}\text { SYSTEM/ } \\
\text { COM!PONENT } \\
\end{array}$ & MEASUREMENT & $\begin{array}{l}\text { CENEFAL } \\
\text { OBJECTIVE }\end{array}$ & PERTINENCE & RESULT & ONSET & DURATION & RECOVERY & DATA & RE FERENCE & AMELIORATION & PROGNOSIS \\
\hline $\begin{array}{l}\text { 3. CARDIOUAS- } \\
\text { CULAR } \\
\text { SYSTEM }\end{array}$ & & & & & & & & & & & \\
\hline $\begin{array}{l}\text { Hemociynanics } \\
\text { Vas cul ature }\end{array}$ & $\begin{array}{l}\text { Compliance, } \\
\text { pre, in, post } \\
\text { flight }\end{array}$ & $\begin{array}{l}\text { Vascular } \\
\text { parameters }\end{array}$ & $\begin{array}{l}\text { Somerihat contro- } \\
\text { versal applica- } \\
\text { tion to assess- } \\
\text { ment of cardio- } \\
\text { vascular adapta- } \\
\text { bility }\end{array}$ & $\begin{array}{l}\text { increased } \\
\text { compliancia }\end{array}$ & $\begin{array}{l}\text { Gradual } \\
\text { over } \\
\text { more } \\
\text { than } \\
0 \text { days }\end{array}$ & $\begin{array}{l}\text { Lessening } \\
\text { throughout } \\
\text { mission }\end{array}$ & $\begin{array}{l}\text { Several } \\
\text { days } \\
\text { postflight }\end{array}$ & Skylab & $\begin{array}{l}\text { Thoriton } \\
12\end{array}$ & $\begin{array}{l}\text { Perhaps exercise } \\
\text { and tonus boosters } \\
\text { (neurohumoral) }\end{array}$ & $\begin{array}{l}\text { Although effect is } \\
\text { maximal in time } \\
\text { frame of Shuttle } \\
\text { landing, prognosis } \\
\text { is favorable in } \\
\text { longer missions. }\end{array}$ \\
\hline $\begin{array}{c}\text { 2. Hema tology } \\
\text {.. }\end{array}$ & $\begin{array}{l}\text { Polymorpho- } \\
\text { nuclear } \\
\text { leucocyte } \\
\text { response } \\
\text { (phagocy- } \\
\text { tosis) fre } \\
\text { and post } \\
\text { flight }\end{array}$ & $\begin{array}{l}\text { Adequacy of } \\
\text { phagocjutic } \\
\text { defense } \\
\text { response }\end{array}$ & $\begin{array}{l}\text { In vitro measure- } \\
\text { ment of phago- } \\
\text { cytic activity } \\
\text { of leukocytes } \\
\text { (migrate and } \\
\text { phagocytize) }\end{array}$ & $\begin{array}{l}\text { Ho signit: } \\
\text { izant } \\
\text { change in } \\
\text { ayy step } \\
\text { of the } \\
\text { pocess }\end{array}$ & $\begin{array}{l}\text { N/A } \\
\vdots \\
\vdots\end{array}$ & N/A & $N / A$ & ASTP & $\begin{array}{l}\text { Martin } \\
99\end{array}$ & $N / A$ & $\begin{array}{l}\text { Favorable. It is } \\
\text { probable that } \\
\text { zero-G exposure } \\
\text { has no significart } \\
\text { effect on phago- } \\
\text { cytic capabilities. } \\
\text { Data may have been } \\
\text { compromised by in- } \\
\text { advertent exposure } \\
\text { of astronauts to } \\
\text { toxic gases during } \\
\text { recovery. }\end{array}$ \\
\hline Hema tology & $\begin{array}{l}\text { Leucosyte } \\
\text { counts } \\
\text { pre and } \\
\text { postflight }\end{array}$ & $\begin{array}{l}\text { Adequacy of } \\
\text { phagocy=ic } \\
\text { defense } \\
\text { response }\end{array}$ & & $\begin{array}{l}\text { Tctal } \\
\text { count } \\
\text { typica: } 1 y \\
\text { elevated }\end{array}$ & Unknown & Unknown & $\begin{array}{l}\text { Quick re- } \\
\text { covery (3 } \\
\text { days or } \\
\text { perhaps } \\
\text { longer). }\end{array}$ & Skylab & $\underset{14}{\text { Kimzej }}$ & None & $\begin{array}{l}\text { Favorable. Firm } \\
\text { evaluation of sig- } \\
\text { nificance is not } \\
\text { possible. }\end{array}$ \\
\hline Hena tology & $\begin{array}{l}\text { Red cell } \\
\text { shape charges } \\
\text { pre, in, } \\
\text { post flight }\end{array}$ & $\begin{array}{l}\text { Hematolcgi- } \\
\text { cal re- } \\
\text { sporse to } \\
\text { weightlex.s- } \\
\text { ness }\end{array}$ & $\begin{array}{l}\text { Direct measure of } \\
\text { erythrocyte } \\
\text { response of un- } \\
\text { known etiology }\end{array}$ & $\begin{array}{l}\text { Many dis- } \\
\text { orjerec } \\
\text { ceils } \\
\text { pesking } \\
\text { at } 4 \text { weeks }\end{array}$ & $<3$ days & Throughout & $\begin{array}{l}\text { Not deter- } \\
\text { mined. In:- } \\
\text { provement } \\
\text { was } \\
\text { measured } \\
\text { in fl ight. } \\
\text { Abrupt } \\
\text { charige to } \\
\text { normal up- } \\
\text { on flight } \\
\text { completion. }\end{array}$ & Skylat & $\begin{array}{c}\text { K:mieji } \\
\text { lc. }\end{array}$ & None suggested. & $\begin{array}{l}\text { Not grossly un- } \\
\text { favorable. Celiular } \\
\text { changes did not } \\
\text { change in vitro } \\
\text { performance or } \\
\text { hamper human per- } \\
\text { formance. }\end{array}$ \\
\hline Hena tology & $\begin{array}{l}\text { Plasma volume } \\
\text { pre, post- } \\
\text { flight }\end{array}$ & $\begin{array}{l}\text { Volume } \mathrm{dz} \\
\text { termination }\end{array}$ & $\begin{array}{l}\text { Direct measure- } \\
\text { nent }\end{array}$ & $\mid \begin{array}{l}10 \% \\
\text { duction at } \\
\text { recover. }\end{array}$ & $V / A$ & $N / A$ & $\begin{array}{l}\text { About } 2 \\
\text { weeks }\end{array}$ & Skylab & $\begin{array}{l}\text { Johnson } \\
13\end{array}$ & $\begin{array}{l}\text { Adaptation to zero- } \\
\text { g results in pro- } \\
\text { gressive loss of } \\
\text { plasma volume, } \\
\text { possibly counter- } \\
\text { able by prodigious } \\
\text { levels of exer- } \\
\text { cise. }\end{array}$ & $\begin{array}{l}\text { Not favorable. Pro- } \\
\text { gressive loss of } \\
\text { plasma volume causes } \\
\text { handicap at recovery } \\
\text { but not in flight, } \\
\text { based on energy } \\
\text { metabol ism studies } \\
\text { (Michel) }\end{array}$ \\
\hline
\end{tabular}


INVENTORY OF HUMAN RESPONSES TO SPACE FLIGHT

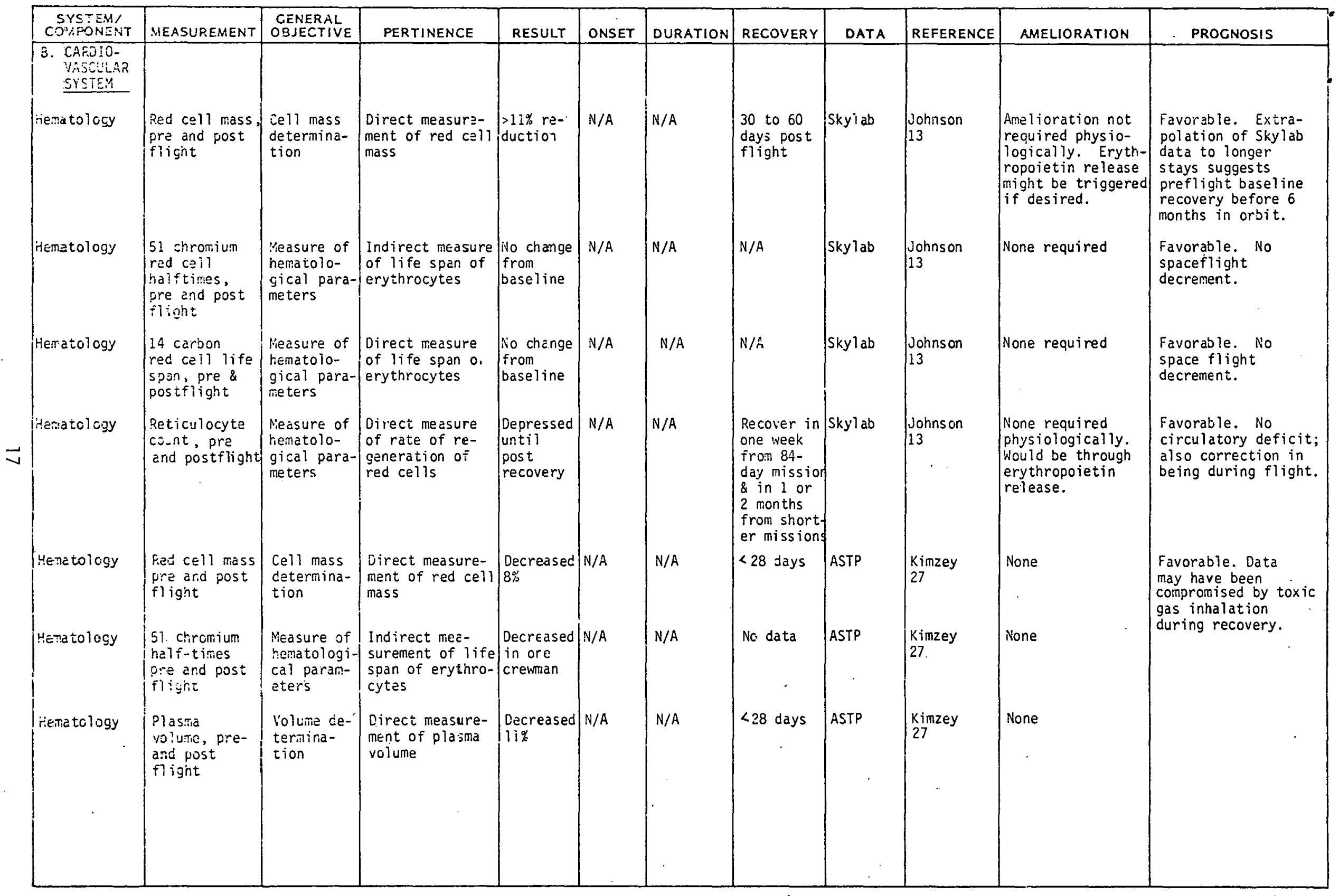


INVENTORY OF HUMAN RESFONSES TO SPACE FLIGHT

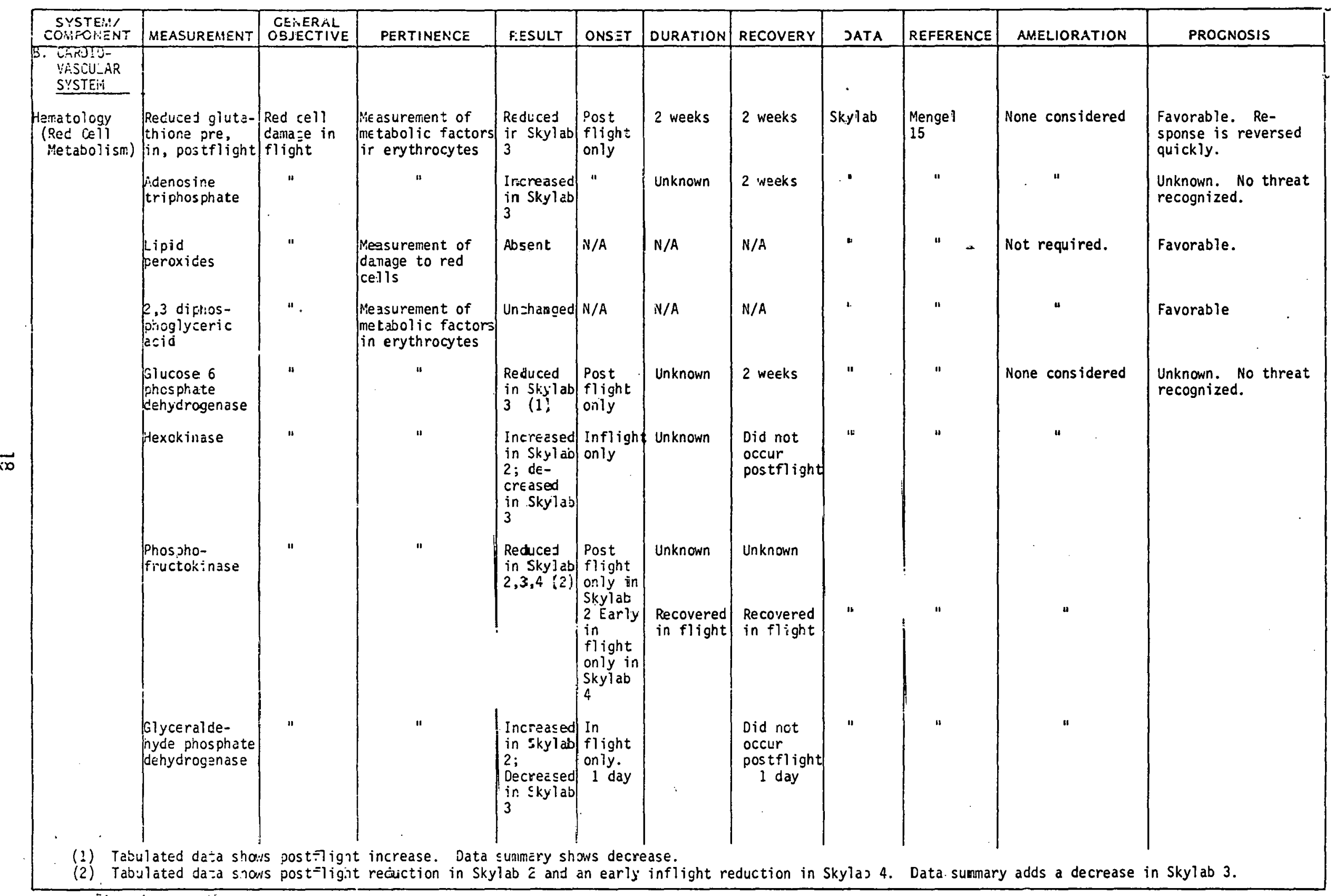


INVENTORY OF HUMAN RESPONSES TO SPACE FLIGHT

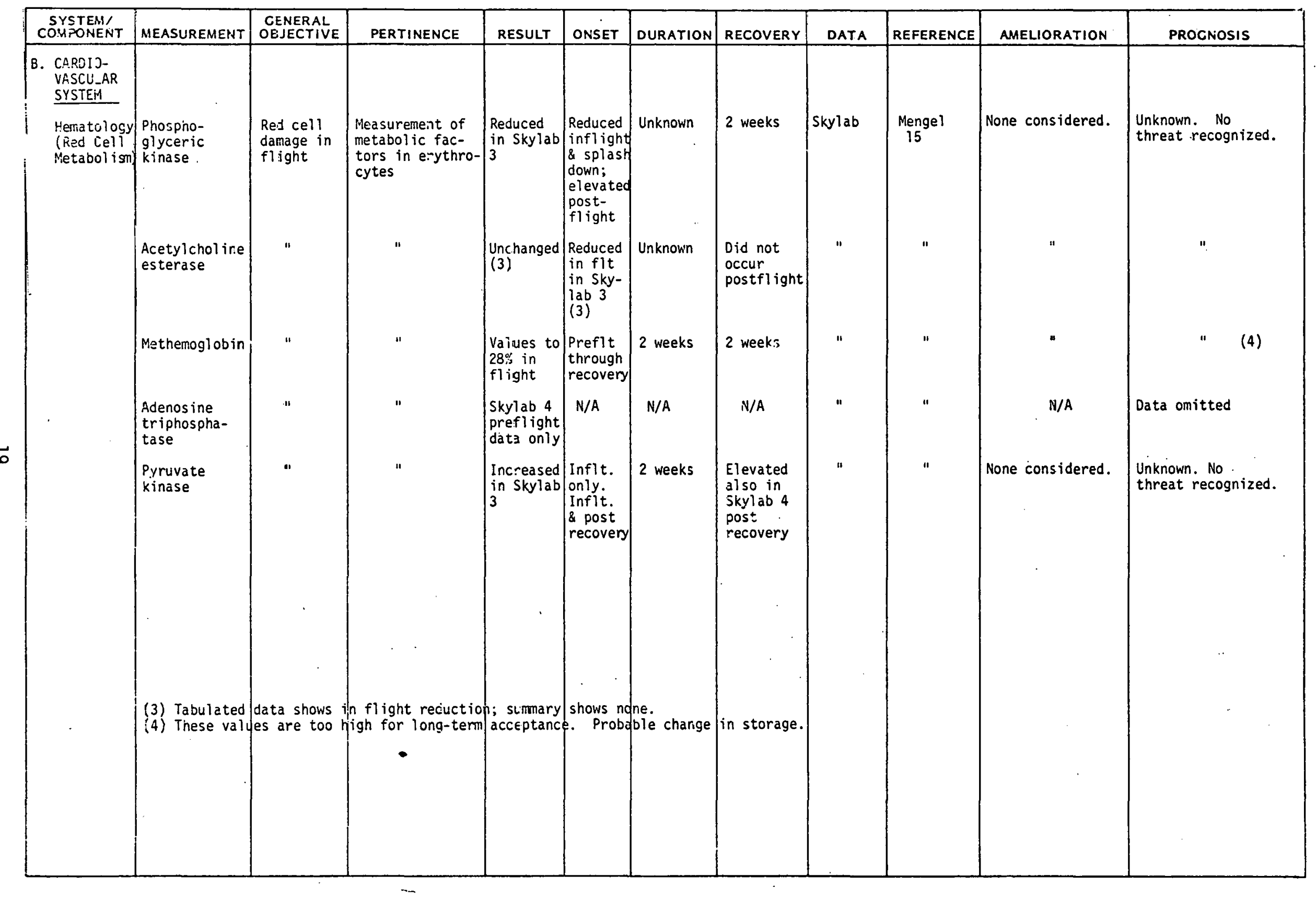


INYEITORY OF HUHAN RESPONSES TO SPACE FLIGHT

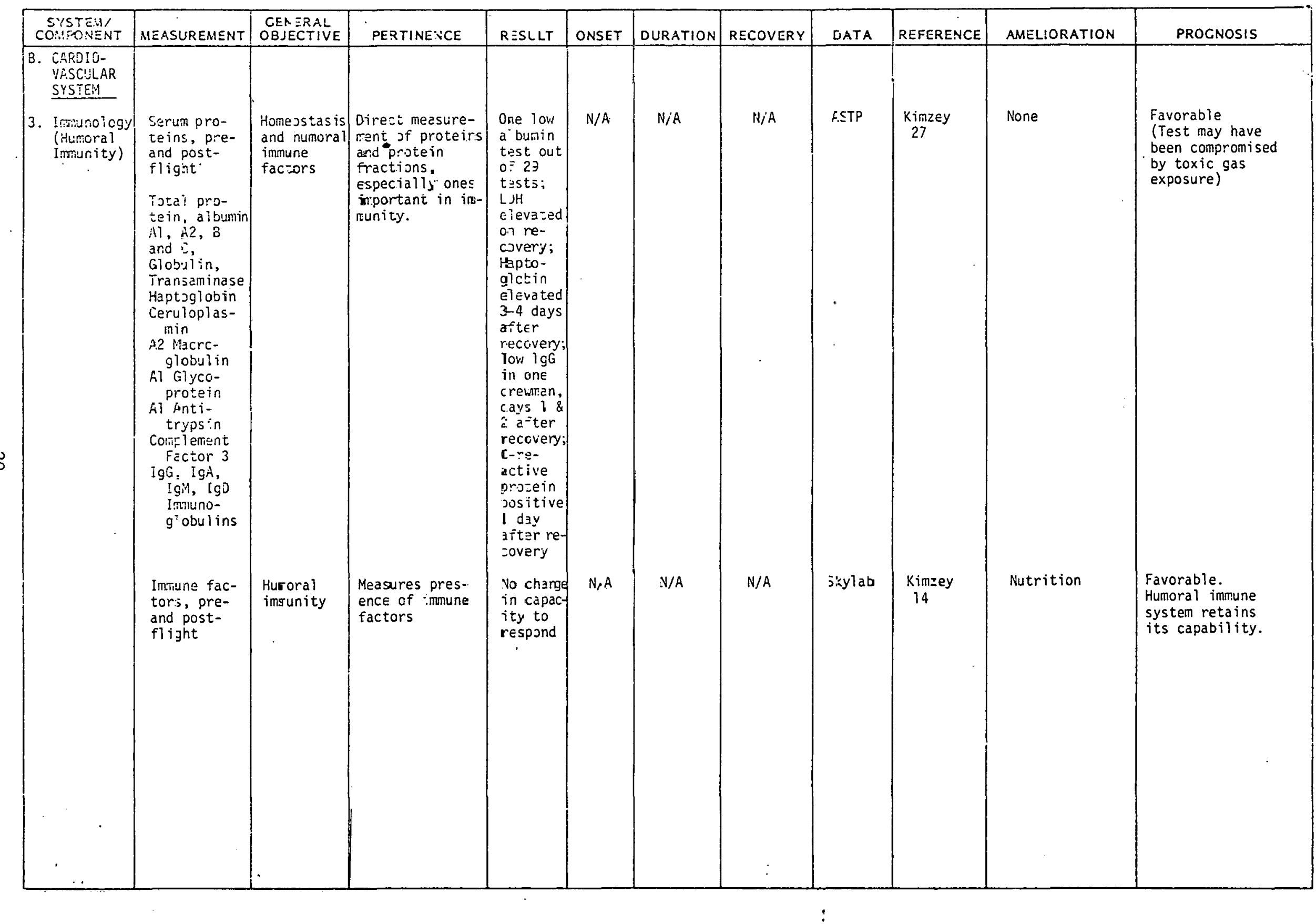


INVENTORY OF HUMAN RESPONSES TO SPACE FLIGHT

\begin{tabular}{|c|c|c|c|c|c|c|c|c|c|c|c|}
\hline $\begin{array}{l}\text { SYSTEEA' } \\
\text { COHFONENT }\end{array}$ & MEASUREMENT & $\begin{array}{l}\text { CENERAL } \\
\text { OBJECTIVE } \\
\end{array}$ & PERTINENCE & RESULT & ONSET & DURATION & RECOVERY & DATA & REFERENCE & AMELIORATION & PROCNOSIS \\
\hline \multicolumn{12}{|l|}{$\begin{array}{l}\text { B. CARDIO- } \\
\text { VASCUIAR } \\
\text { SYSTEVI } \\
\end{array}$} \\
\hline \multirow[t]{4}{*}{$\begin{array}{l}\text { 3. Im:neunoiogy } \\
\text { (Cellular } \\
\text { Idmunity) }\end{array}$} & $\begin{array}{l}\text { Cellular im- } \\
\text { mune system } \\
\text { pre- and post- } \\
\text { flignt }\end{array}$ & $\begin{array}{l}\text { Adeq-dacy of } \\
\text { imiune } \\
\text { response }\end{array}$ & In vitro test & $\begin{array}{l}\text { Decrease } \\
\text { in abil ity } \\
\text { to react } \\
\text { to foreign } \\
\text { substancs }\end{array}$ & N/A & $N / A$ & $\begin{array}{l}\text { By } 8 \text { days } \\
\text { post re- } \\
\text { covery }\end{array}$ & ASTP & $\begin{array}{l}\text { Criswell } \\
37\end{array}$ & None & $\begin{array}{l}\text { Questionable. } \\
\text { Also no disease } \\
\text { process appeared. } \\
\text { Test may have been } \\
\text { compromised by } \\
\text { toxic gas exposure } \\
\text { and cortisol } \\
\text { therapy. }\end{array}$ \\
\hline & $\begin{array}{l}\text { Imnune re- } \\
\text { sponses, (in } \\
\text { vitro) pre } \\
\text { and post- } \\
\text { flight }\end{array}$ & $\begin{array}{l}\text { Celldlar } \\
\text { immunity } \\
\text { (in vitro) }\end{array}$ & $\begin{array}{l}\text { Measures capa- } \\
\text { bility to re- } \\
\text { spond to chal- } \\
\text { lenges (in } \\
\text { vitro) }\end{array}$ & $\begin{array}{l}\text { Reduzed } \\
\text { response } \\
\text { to PHA } \\
\text { test; } \\
\text { nomal } \\
\text { culture } \\
\text { response }\end{array}$ & $N / A$ & $N / A$ & 3-7 days & Skylab & $\underset{14}{\text { Ximzey }}$ & Nutrition & $\begin{array}{l}\text { Questionable } \\
\text { response at } \\
\text { splashdown, but } \\
\text { normal responses } \\
\text { recovered in days }\end{array}$ \\
\hline & $\begin{array}{l}\text { Response of } \\
\text { iymphocytes to } \\
\text { in vitro chal- } \\
\text { lenges pre- } \\
\text { and post- } \\
\text { flight }\end{array}$ & $\begin{array}{l}\text { Integrity } \\
\text { of cellular } \\
\text { immune } \\
\text { system }\end{array}$ & $\begin{array}{l}\text { Relevance to im- } \\
\text { mune response } \\
\text { capability }\end{array}$ & $\begin{array}{l}\text { Decreased } \\
\text { response } \\
\text { postflight } \\
\text { to PHA } \\
\text { challenge }\end{array}$ & Unknown & Unknown & $\begin{array}{l}3-7 \text { days } \\
\text { postflight }\end{array}$ & Skylab & ${ }_{14}^{\text {Kimzey }}$ & None & $\begin{array}{l}\text { Favorable. Firm } \\
\text { evaluation of } \\
\text { significance of } \\
\text { these findings } \\
\text { is not possib?e. }\end{array}$ \\
\hline & $\begin{array}{l}\text { Lymphocyte } \\
\text { counts, pre } \\
8 \text { postflight }\end{array}$ & $\begin{array}{l}\text { Integrity } \\
\text { of cellular } \\
\text { immine } \\
\text { system }\end{array}$ & $\begin{array}{l}\text { Relevance to im- } \\
\text { mune resporise } \\
\text { capability }\end{array}$ & $\begin{array}{l}\text { Reduction } \\
\text { in T-cells } \\
\text { on re- } \\
\text { covery }\end{array}$ & Unknam & Unknown & $\begin{array}{l}\text { 3 days } \\
\text { postflight }\end{array}$ & Skylab & $\underset{14}{\text { Kimzey }}$ & None & $"$ \\
\hline $\begin{array}{l}\text { iSaliva mi- } \\
\text { muriology). }\end{array}$ & $\begin{array}{l}\text { Capability of } \\
\text { cefense } \\
\text { rechanisms }\end{array}$ & $\begin{array}{l}\text { Adequacy } \\
\text { of immunity } \\
\text { (1) Saliva 1e }\end{array}$ & $\begin{array}{l}\text { In vitro data } \\
\text { vel is thought to }\end{array}$ & $\begin{array}{l}\text { No demion- } \\
\text { strable } \\
\text { change in } \\
\text { antibodieg } \\
\text { or lyso- } \\
\text { zyme } \\
\text { levels in } \\
\text { serum ard } \\
\text { saliva(1) } \\
\text { be represe }\end{array}$ & N/A & N/A & $N / A$ & ASTP & $\begin{array}{l}\text { Taylor } \\
29\end{array}$ & $N / A$ & $\begin{array}{l}\text { Favorable. These } \\
\text { data were in part } \\
\text { taken after ex- } \\
\text { posure of the crew } \\
\text { to toxic gases } \\
\text { and are partially } \\
\text { questionable as } \\
\text { zero-G related } \\
\text { effects. }\end{array}$ \\
\hline
\end{tabular}


INVENTORY OF HUMAN RESPONSES TO SPACE FLIGHT

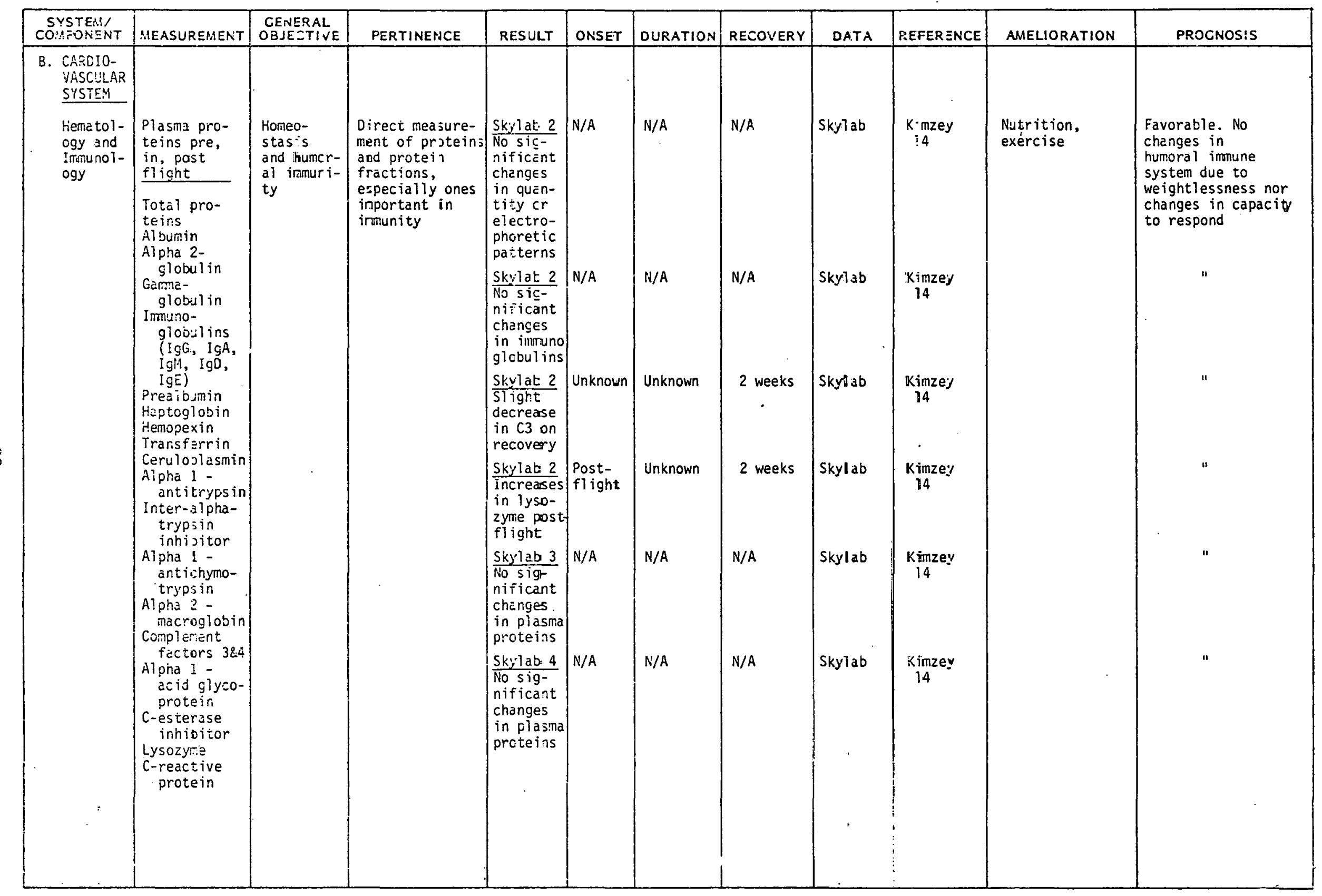


INVENTORY OF HUMAN RESPONSES TO SPACE FLIGHT

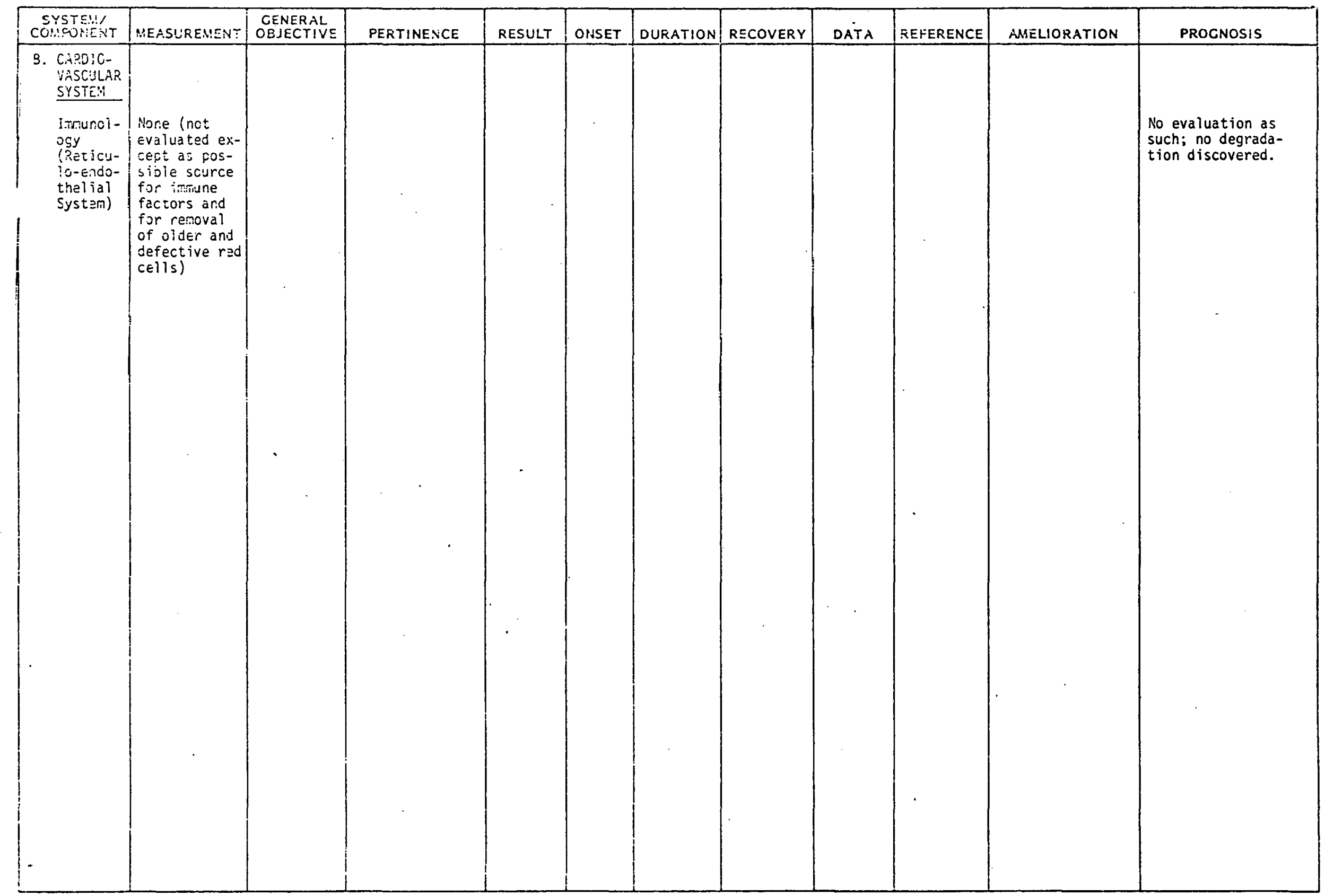


INVENTORY OF HURAN RESPONSES TO SPACE FLIGHT

\begin{tabular}{|c|c|c|c|c|c|c|c|c|c|c|c|}
\hline $\begin{array}{l}\text { SYSTEHA } \\
\text { COMPONENT }\end{array}$ & MEASUREMENT & $\begin{array}{l}\text { CENERAL } \\
\text { OEJECTIVE }\end{array}$ & PERTINENCE & RESULT & ONSET & DURATION & RECOVERY & DATA & P.EFERENCE & AMELIORATION & PROCNOSIS \\
\hline \multicolumn{12}{|l|}{$\begin{array}{l}\text { c. NERTIOUS } \\
\text { SYSTEM } \\
\text { TSTEY }\end{array}$} \\
\hline Central & $\begin{array}{l}\text { Task perform- } \\
\text { ance pre, in, } \\
\text { postflight }\end{array}$ & Hol stic & $\begin{array}{l}\text { Evaluates be- } \\
\text { havioral per- } \\
\text { formance }\end{array}$ & $\begin{array}{l}\text { Baselire } \\
\text { ecualled } \\
\text { after few } \\
\text { trials }\end{array}$ & N/A. & N/A & $\mathrm{N} / \mathrm{A}$ & Skylab & $\begin{array}{l}\text { kuivis } \\
31\end{array}$ & $N / A$ & $\begin{array}{l}\text { Favorable; perform- } \\
\text { ance cont inues to } \\
\text { improve with time. }\end{array}$ \\
\hline Central & $\left\{\begin{array}{l}\text { Sleep types } \\
\text { and adequacy } \\
\text { by el Ectro- } \\
\text { encephalogram }\end{array}\right.$ & Holistic & $\begin{array}{l}\text { Evaluates } \\
\text { adequacy of } \\
\text { sleep }\end{array}$ & Aciequate & N/A & $N / A$ & $N / A$ & Skylab & $\begin{array}{l}\text { Frost } \\
35\end{array}$ & None Required & $\begin{array}{l}\text { Favorable; in post- } \\
\text { flight period thera } \\
\text { is more REM sleep and } \\
\text { it appears sooner }\end{array}$ \\
\hline Peripheral & $\begin{array}{l}\text { Achilles } \\
\text { teridon re- } \\
\text { f?exes pre, } \\
\text { postfight }\end{array}$ & $\begin{array}{l}\text { Reflex time } \\
\text { measurement }\end{array}$ & $\begin{array}{l}\text { Mea sures several } \\
\text { elements incluc- } \\
\text { ing nerve con- } \\
\text { duction }\end{array}$ & $\begin{array}{l}\text { Generally } \\
\text { reduced } \\
\text { tine in } \\
\text { Skylaj } 3 \\
\text { and } 4\end{array}$ & - & - & $\begin{array}{l}\text { By } 31 \text { days } \\
\text { post- } \\
\text { recovery }\end{array}$ & Sk, lab & $\begin{array}{l}\text { Baker } \\
32\end{array}$ & 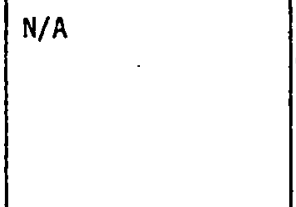 & $\begin{array}{l}\text { Reflex times lengthen- } \\
\text { ed during the month } \\
\text { after recovery before } \\
\text { becoming basel ine. } \\
\text { No suggested un- } \\
\text { favorable prognosis. }\end{array}$ \\
\hline Peripheral & $\begin{array}{l}\text { Achilles } \\
\text { tendor re } i l=x \\
\text { perioc } \frac{1}{2} \\
\text { relaxation, } \\
\text { pre and post } \\
\text { flight }\end{array}$ & $\begin{array}{l}\text { Reflex time } \\
\text { measurement }\end{array}$ & $\begin{array}{l}\text { Neasures several } \\
\text { elements includ- } \\
\text { ing nerve con- } \\
\text { duction }\end{array}$ & $\begin{array}{l}\text { Twa men } \\
\text { had } \\
\text { shartened } \\
\text { beriods, } \\
\text { the } 3 r d \\
\text { horger. } \\
\text { There was } \\
\text { a fine } \\
\text { trenor. }\end{array}$ & $N / A$ & N/A & Unknown & AST:P & $\begin{array}{l}\text { Burchiard } \\
18\end{array}$ & $\begin{array}{l}\text { None (This measure } \\
\text { ment is related to } \\
\text { thyroxine level.) }\end{array}$ & $\begin{array}{l}\text { Tremor may have been } \\
\text { caused by toxic ex- } \\
\text { posure. 0ther data } \\
\text { as anticipated. } \\
\text { fa. e prognosis. }\end{array}$ \\
\hline Autonomic & $\begin{array}{l}\text { Pre, in, fost } \\
\text { fl ight heart } \\
\text { rate }\end{array}$ & Holistic & $\begin{array}{l}\text { Evaluates sympa.- } \\
\text { thetic activity }\end{array}$ & $\begin{array}{l}\text { Accel- } \\
\text { eratec } \\
\text { rates }\end{array}$ & & $\begin{array}{l}\text { Throughout } \\
\text { worst at } \\
3 \text { weeks } \\
\text { (LB:NP) }\end{array}$ & $\begin{array}{l}\text { Within } \\
11 \text { days }\end{array}$ & Sky]ab & $\begin{array}{l}\text { Jchnson } \\
8 \\
\text { Hoffler } \\
7\end{array}$ & $N / A$ & $\begin{array}{l}\text { Favorable. Cardio- } \\
\text { vascular control } \\
\text { mechanisms operative. }\end{array}$ \\
\hline As a wrole & $\begin{array}{l}\text { Neuro- } \\
\text { psychelogical: } \\
\text { tensicn, } \\
\text { fatigle, } \\
\text { circadian } \\
\text { rhythr, } \\
\text { stress } \\
\text { responses }\end{array}$ & $\begin{array}{l}\text { Eehavior: } \\
\text { capat:lity } \\
\text { in space, } \\
\text { stress ir: } \\
\text { space }\end{array}$ & $\begin{array}{l}\text { Assessment of } \\
\text { kapability in } \\
\text { wightless } \\
\text { environment }\end{array}$ & $\begin{array}{l}\text { No } \\
\text { mission } \\
\text { imfair- } \\
\text { mert } \\
\text { (sea al so } \\
\text { Endocrine } \\
\text { Systen \& } \\
\text { Biochem- } \\
\text { istey) }\end{array}$ & $N / A$ & $N / A$ & $N / A$ & Gereral & $\begin{array}{l}\text { Pestor } \\
53\end{array}$ & 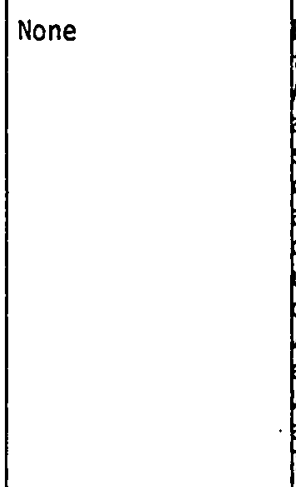 & $\begin{array}{l}\text { Favorable. Any dis- } \\
\text { kurbances such as } \\
\text { fpollo } 13 \text { accidert } \\
\text { and new experiences } \\
\text { such as space v'alking, } \\
\text { docking, lunar landirig } \\
\text { and exploration, space } \\
\text { construction (Skylab } \\
\text { umbrella), and re- } \\
\text { covery from space } \\
\text { were handled in ex- } \\
\text { emplary fasnion: } \\
\text { leightlessness has no } \\
\text { epparent neuropsycho- } \\
\text { flogical effect. }\end{array}$ \\
\hline
\end{tabular}


INVENTORY OF HUMAN RESPONSES TO SPACE FLIGHT

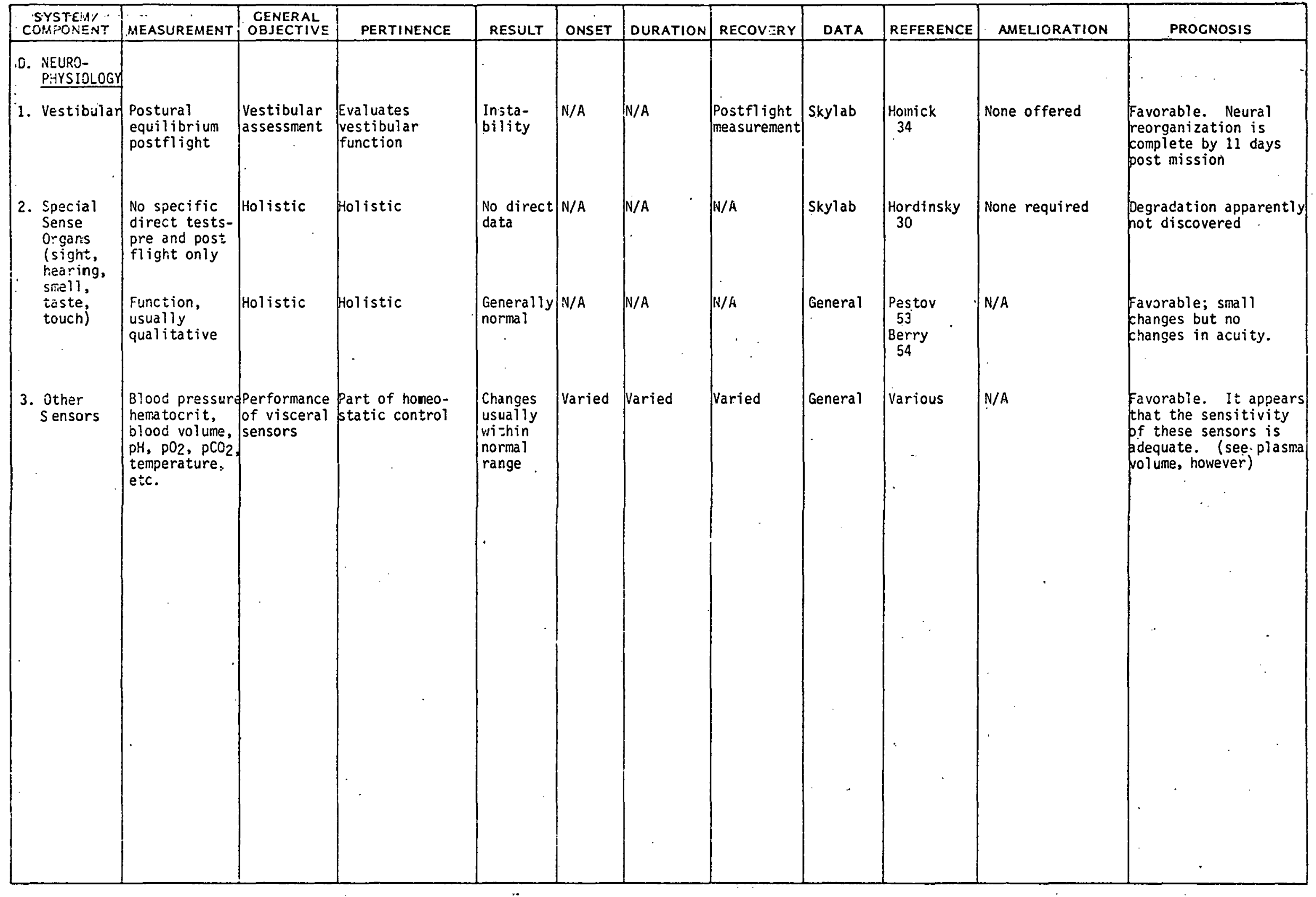


INYENTORY OF HUMAN RESPONSES TO SPACE FLIGHT

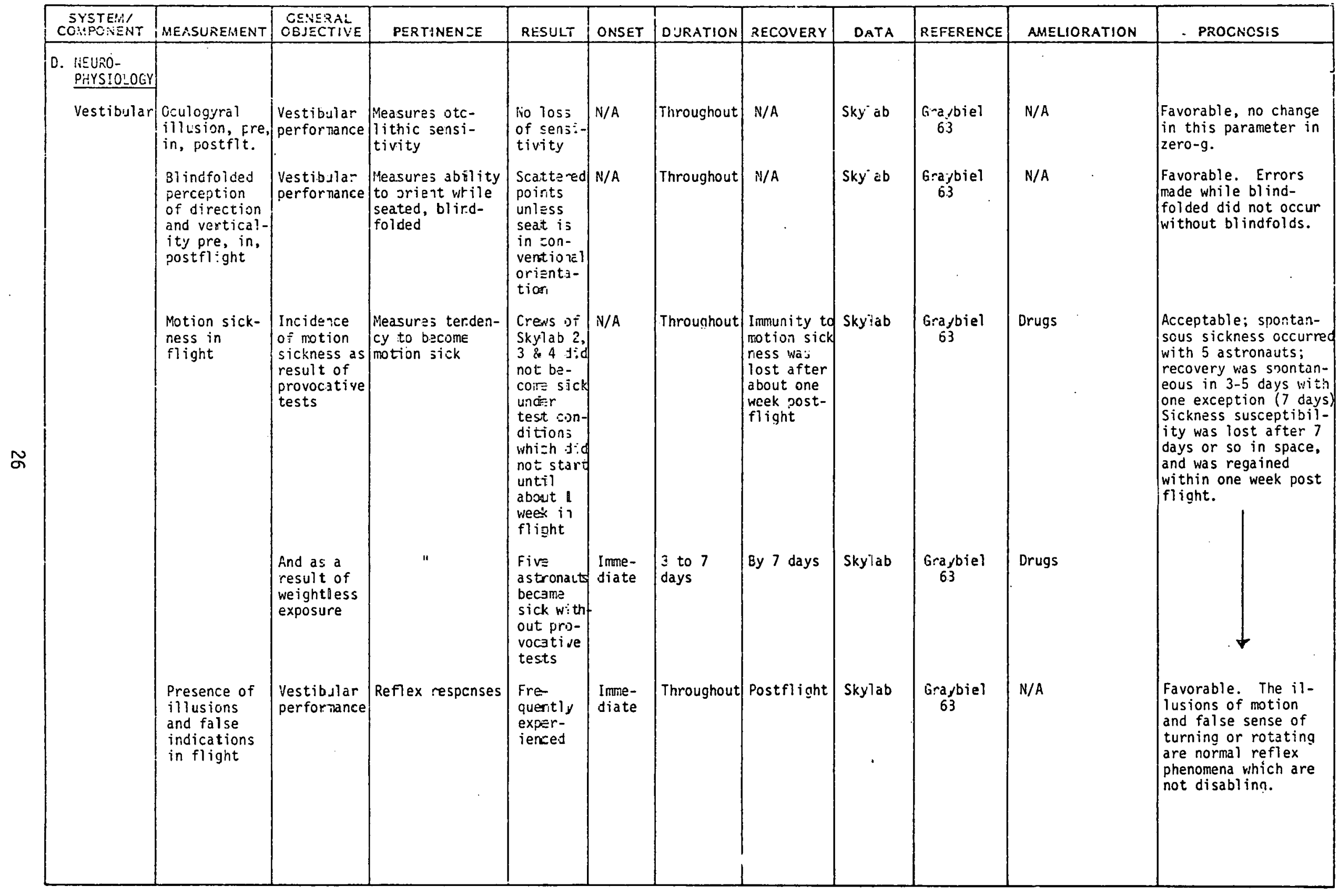


INVENTORY OF HUMAN RESPONSES TO SPACE FLIGHT

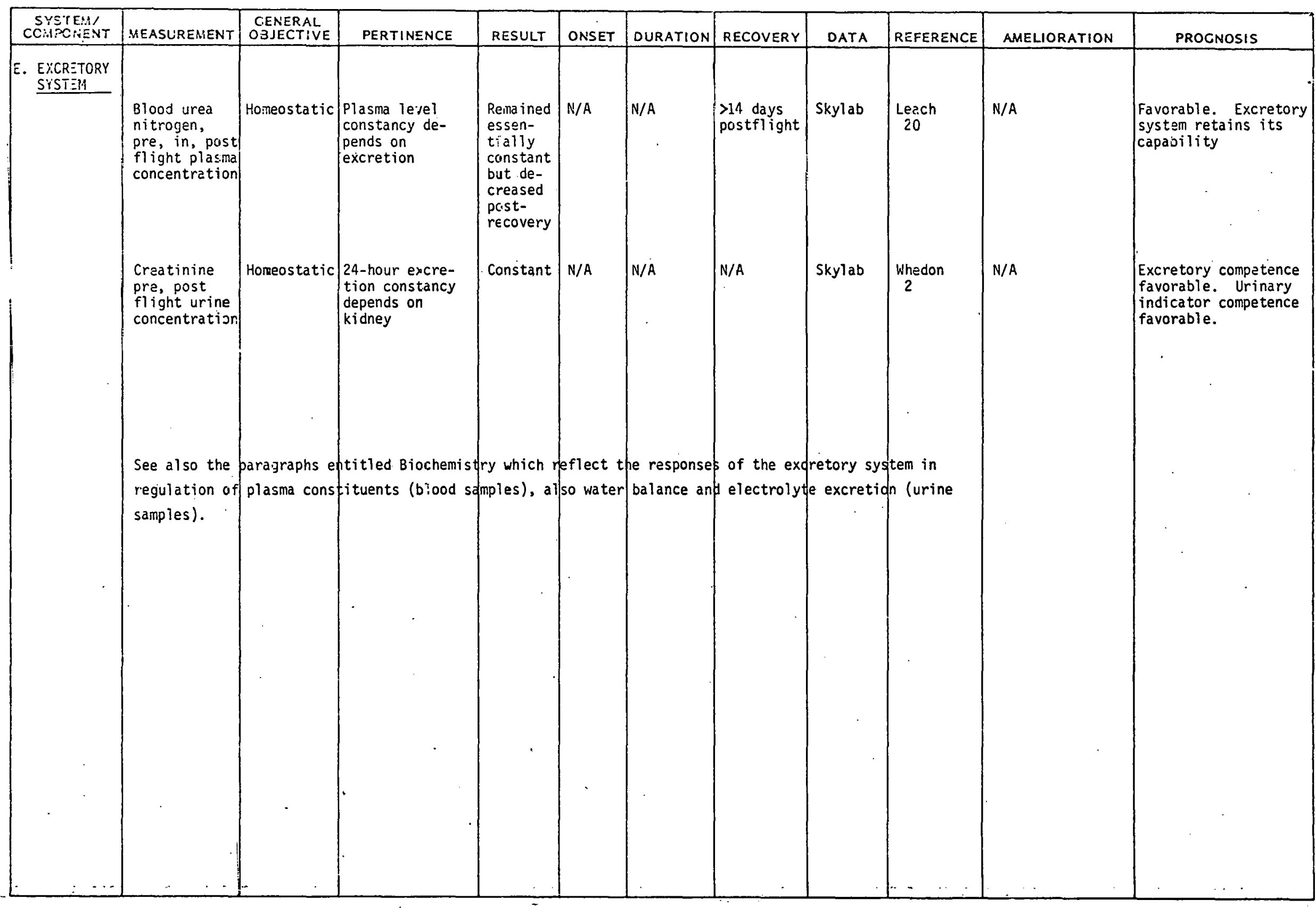


INVENTORY OF HUMAN RESPONSES TO SPACE FLIGHT

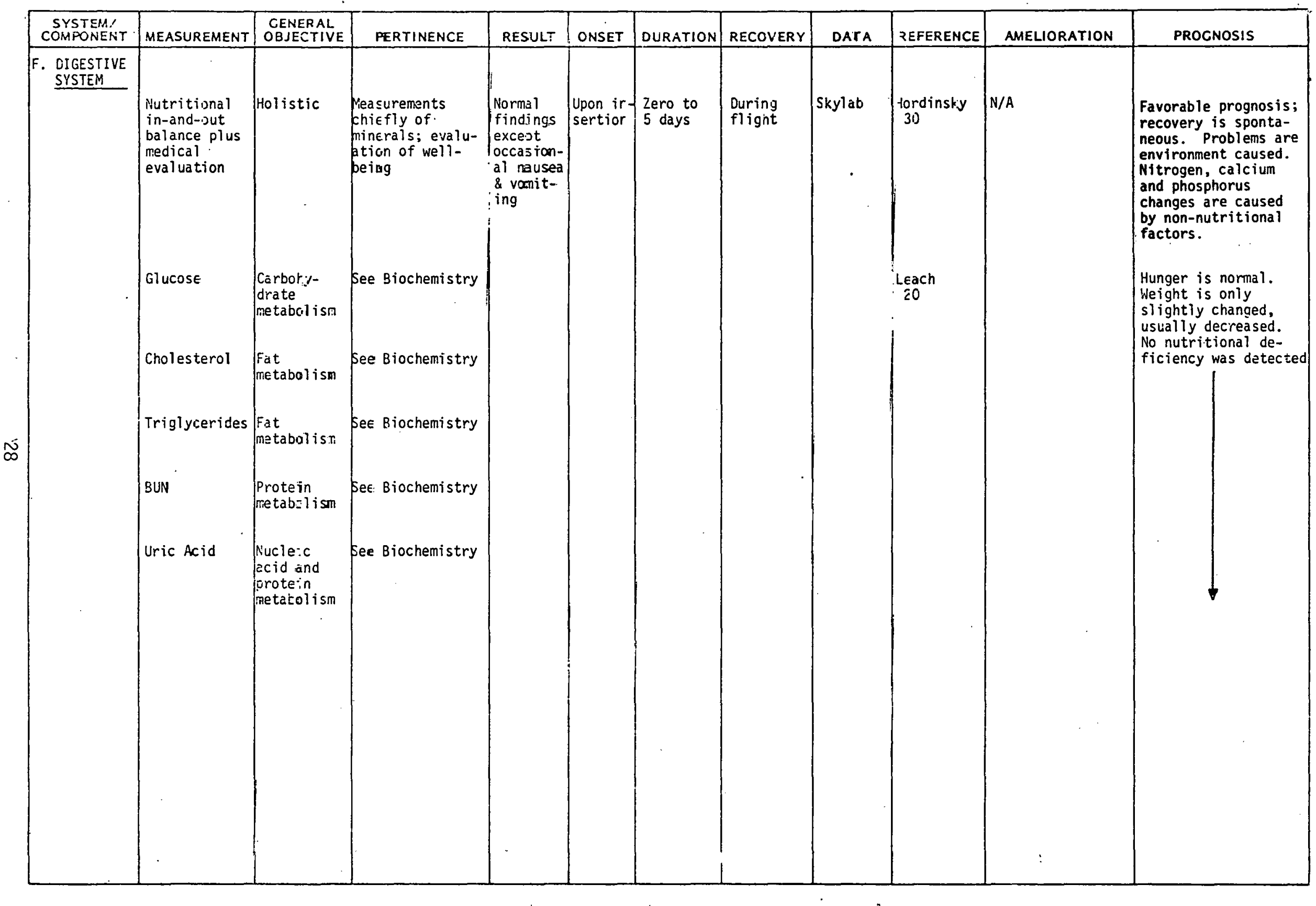


INVENTORY OF HUPAAN RESPONSES TO SPACE FLIGHT

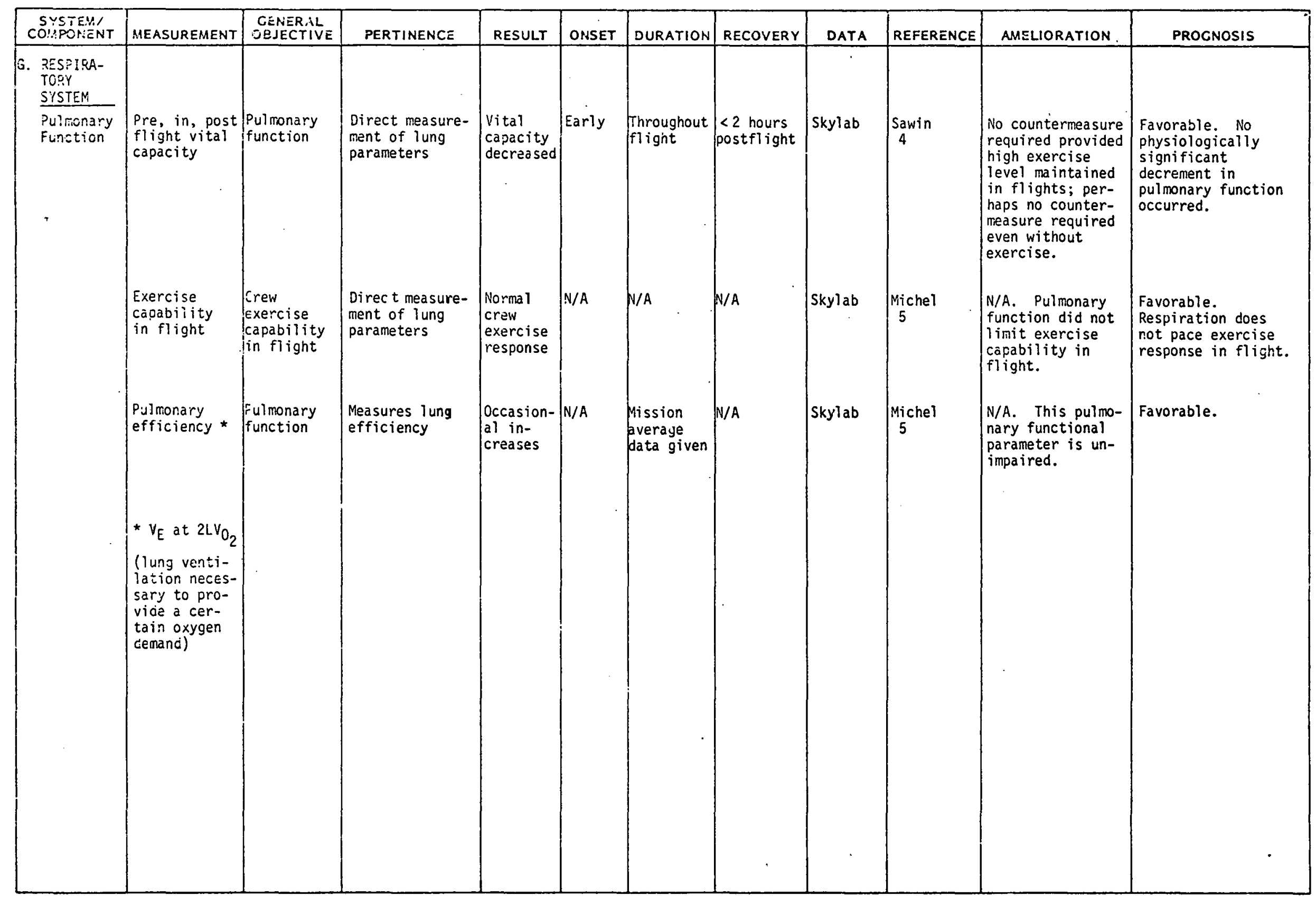


INVENTORY OF HUMAN RESPONSES TO SPACE FLIGHT

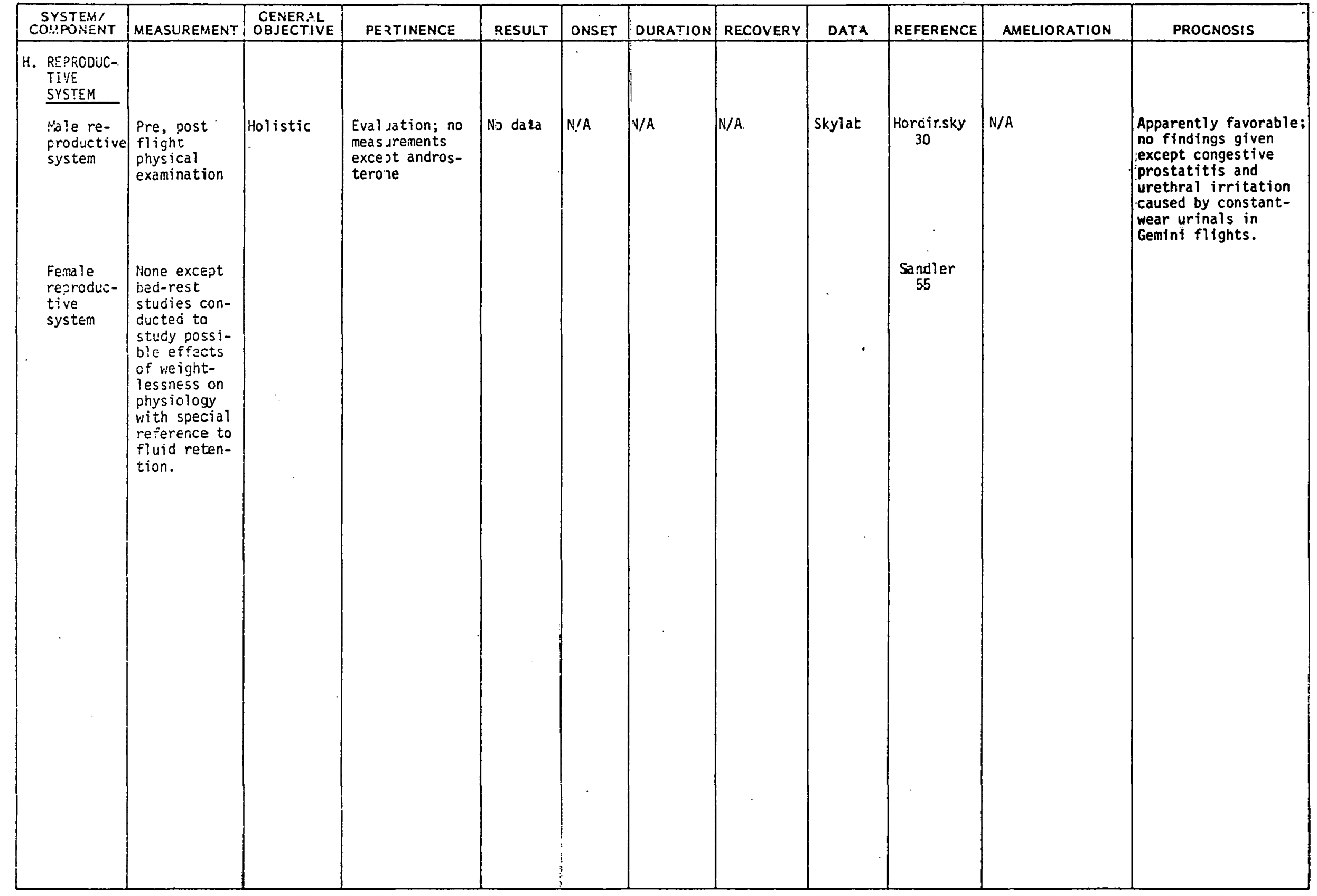


INVENTORY OF HUMAN RESPONSES TO SPACE FLIGHT

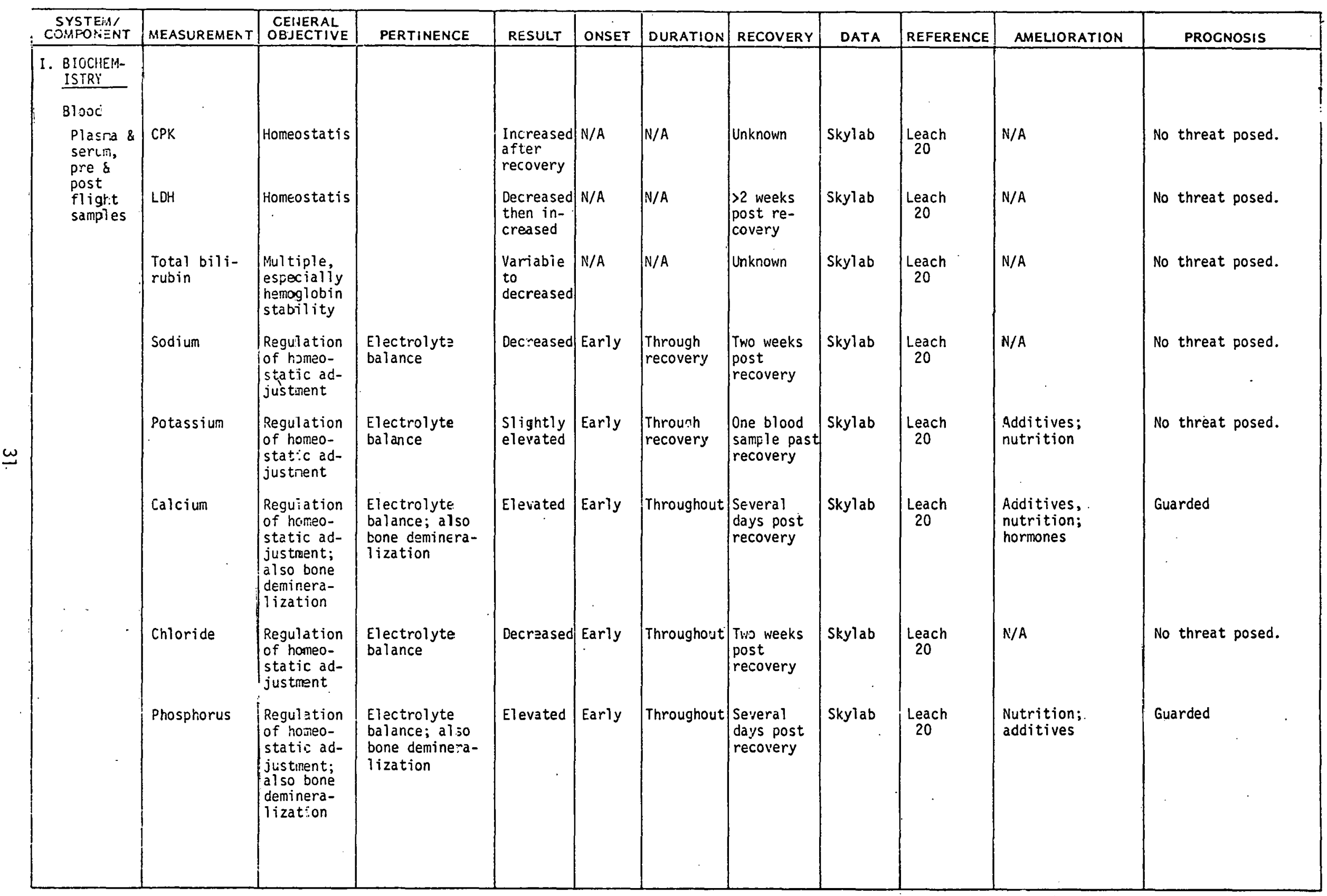


INVENTORY OF HUMAN RESPONSES TO SPACE FLIGHT

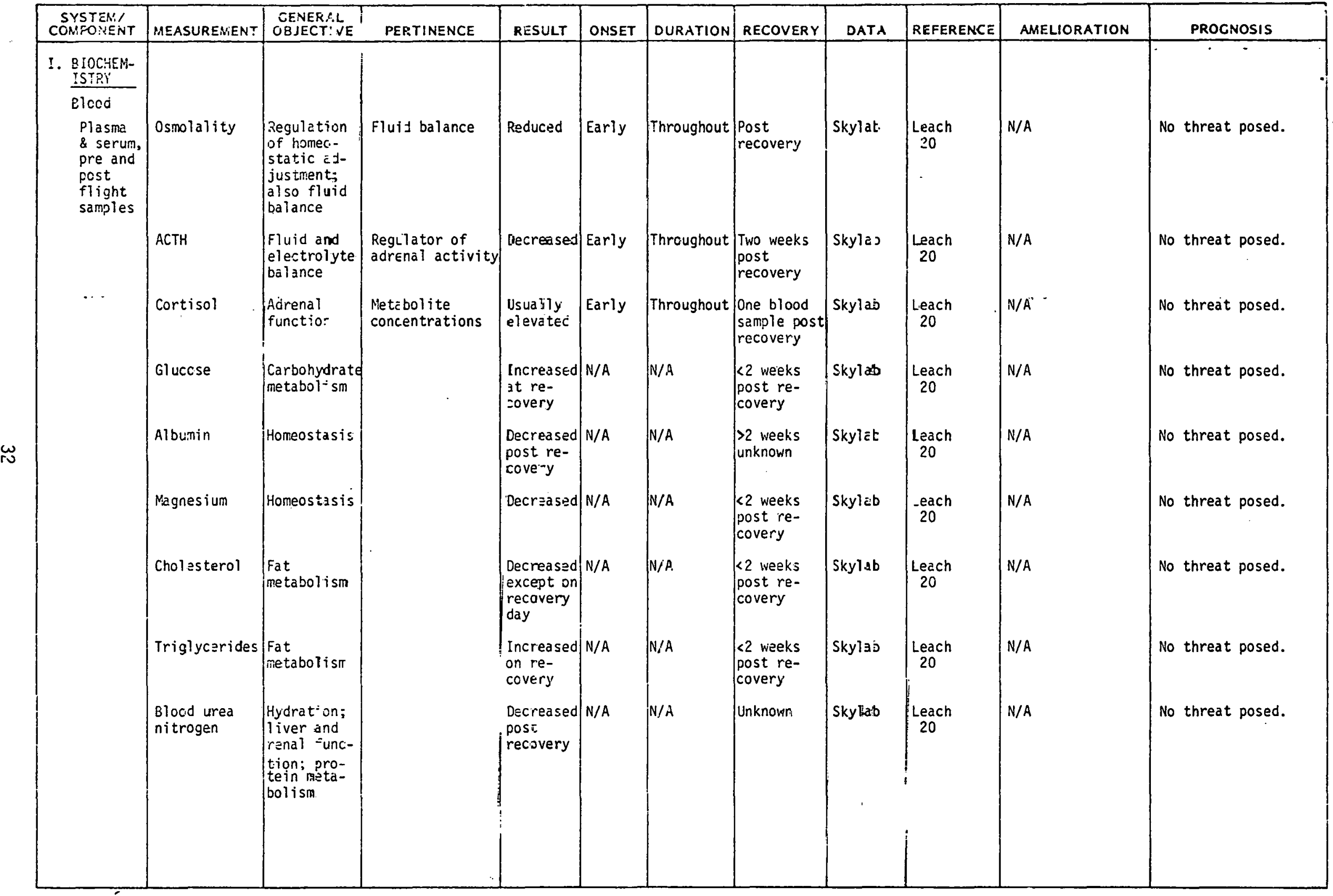


INVENTORY OF HUHAN RESPONSES TO SPACE FIIGHT

\begin{tabular}{|c|c|c|c|c|c|c|c|c|c|c|c|}
\hline $\begin{array}{l}\text { SYSTEM/ } \\
\text { COHPONENT }\end{array}$ & HEASUন̃EMENT & $\begin{array}{l}\text { CEIHEPAL } \\
\text { OBJECTIVE } \\
\end{array}$ & PERTINENCE & RESULT & ONSET & DURATION & RECOVERY & DATA & REFERENCE & ANELIORATION & PROCNOSIS \\
\hline \multicolumn{12}{|l|}{$\begin{array}{l}\text { I. EIOCHEM- } \\
\text {-STRY } \\
\end{array}$} \\
\hline Eiood & & & & & & & & & & & \\
\hline \multirow[t]{4}{*}{$\begin{array}{l}\text { P!asma } \\
\text { \& serum, } \\
\text { pre and } \\
\text { post } \\
\text { fligrt } \\
\text { samples }\end{array}$} & Uric acid & $\begin{array}{l}\text { Renal } \\
\text { function, } \\
\text { protein \& } \\
\text { purine } \\
\text { metabolism }\end{array}$ & & $\begin{array}{l}\text { Decreased } \\
\text { post } \\
\text { recovery }\end{array}$ & $N / A$ & $\mathrm{~N} / \mathrm{A}$ & $\begin{array}{l}<2 \text { weeks } \\
\text { post } \\
\text { recovery }\end{array}$ & Skylab & $\begin{array}{l}\text { Leach } \\
20\end{array}$ & N/A & No threat posed. \\
\hline & $\begin{array}{l}\text { Total } \\
\text { protein }\end{array}$ & Homeostasis & & $\begin{array}{l}\text { Increased } \\
\text { on re- } \\
\text { covery }\end{array}$ & $\mathrm{N} / \mathrm{A}$ & $N / A$ & $\begin{array}{l}1 \text { or } 2 \\
\text { days post } \\
\text { recoverji }\end{array}$ & Skylab & $\begin{array}{l}\text { Leach } \\
20\end{array}$ & N/A & No threat pos? \\
\hline & $\begin{array}{l}\text { Alkaline } \\
\text { phosphatáse }\end{array}$ & Homeostasis & & $\begin{array}{l}\text { Reduced } \\
\text { post } \\
\text { recovery }\end{array}$ & $N / A$ & $N / A$ & $\begin{array}{l}<2 \text { weeks } \\
\text { post re- } \\
\text { covery }\end{array}$ & Skylab & $\begin{array}{l}\text { Leach } \\
20\end{array}$ & $N / A$ & No threat posed. \\
\hline & SEOT & Homeostasis & & No change & $\mathrm{N} / \mathrm{A}$ & $N / A$ & $N / A$ & Skylab & $\begin{array}{l}\text { Leach } \\
20\end{array}$ & $N / A$ & No threat posed. \\
\hline \multirow{3}{*}{$\begin{array}{l}81 \text { ood } \\
\text { seruin pre } \\
\text { and pest } \\
\text { flight }\end{array}$} & $\begin{array}{l}\text { Lactic de- } \\
\text { hydrogenzse }\end{array}$ & $\begin{array}{l}\text { Stress; } \\
\text { injury }\end{array}$ & $\begin{array}{l}\text { Evaluation of } \\
\text { well-being }\end{array}$ & $\begin{array}{l}\text { Increased } \\
\text { in three } \\
\text { in wewnen }\end{array}$ & N/A & & $>28$ days & ASTP & $\begin{array}{l}\text { Leach } \\
26\end{array}$ & None & $\begin{array}{l}\text { Uncertain prognosis; } \\
\text { Results may have } \\
\text { been compromised by }\end{array}$ \\
\hline & Osmoiari & Homeostasis & $\begin{array}{l}\text { Evaluation of } \\
\text { well-being } \\
\text {. }\end{array}$ & $\begin{array}{l}\text { Jecreased } \\
\text { in two } \\
\text { crewmen }\end{array}$ & $N / A$ & & $<28$ days & ASTP & $\begin{array}{l}\text { Leach } \\
26\end{array}$ & None & $\begin{array}{l}\text { of astronitits to } \\
\text { toxic gar:s during } \\
\text { recovery. }\end{array}$ \\
\hline & Sodium & Homeostasis & $\begin{array}{l}\text { Evaluation of } \\
\text { well-being }\end{array}$ & $\begin{array}{l}\text { Decreased } \\
\text { in three } \\
\text { crewmen }\end{array}$ & $N / A$ & & $>28$ days & ASTP & $\begin{array}{l}\text { Leach } \\
26\end{array}$ & None & \\
\hline & Potassium & Homeostasis & $\begin{array}{l}\text { Evaluation of } \\
\text { well-being }\end{array}$ & $\begin{array}{l}\text { Increased } \\
\text { in two } \\
\text { crewmen }\end{array}$ & $N / A$ & & $<28$ days & ASTP & $\begin{array}{l}\text { Leach } \\
26\end{array}$ & None & \\
\hline & Chloride & Homeostas is & $\begin{array}{l}\text { Evaluation of } \\
\text { well-being }\end{array}$ & $\begin{array}{l}\text { Increased } \\
\text { in two } \\
\text { crewmen }\end{array}$ & $N / A$ & & $>28$ days & ASTP & $\begin{array}{l}\text { Leach } \\
26\end{array}$ & None & \\
\hline & Triglycerides & $\begin{array}{l}\text { Fat meta- } \\
\text { bol ism }\end{array}$ & $\begin{array}{l}\text { Evaluation of } \\
\text { well-being }\end{array}$ & $\begin{array}{l}\text { Decreased } \\
\text { in two } \\
\text { crewmen }\end{array}$ & $N / A$ & & $>28$ days & ASTP & $\begin{array}{l}\text { Leach } \\
26\end{array}$ & None & \\
\hline & Giucose & $\begin{array}{l}\text { Carbohy- } \\
\text { drate } \\
\text { metabolism }\end{array}$ & $\begin{array}{l}\text { Evaluation of } \\
\text { well-being }\end{array}$ & $\begin{array}{l}\text { Decreased } \\
\text { in two } \\
\text { crewmen }\end{array}$ & $N / A$ & & $<28$ days & ASTP & $\begin{array}{l}\text { Leach } \\
26\end{array}$ & None & \\
\hline & . & & & 4 & & & & & & & - \\
\hline
\end{tabular}


IWVENTORY OF HLMAN RESPONSES TO SPACE FLIGHT

\begin{tabular}{|c|c|c|c|c|c|c|c|c|c|c|c|}
\hline $\begin{array}{l}\text { SYSTEN/ } \\
\text { COMPONENT }\end{array}$ & MEASUREHENT & $\begin{array}{l}\text { CENERAL } \\
\text { OBJECTIVE }\end{array}$ & PERTINENCE & RESULT & ONSET & DURATION & RECOVERY & DAT 4 & REFERENCE & AMELIORATION & PROCNOSIS \\
\hline \multicolumn{12}{|l|}{$\begin{array}{l}\text { I. BIOCHEM- } \\
\text { ISTRY }\end{array}$} \\
\hline \multirow[t]{10}{*}{$\begin{array}{l}\text { Blood } \\
\text { serum pre } \\
\text { and post } \\
\text { fiignt }\end{array}$} & Cholesterol & $\begin{array}{l}\text { Fat metäbo- } \\
\text { lism }\end{array}$ & $\begin{array}{l}\text { Eva:uation of } \\
\text { wel -being }\end{array}$ & $\begin{array}{l}\text { pecreased } \\
\text { in three } \\
\text { erewmen }\end{array}$ & $M / A$ & & $\leqslant 28$ days & ASTP & $\begin{array}{l}\text { Leach } \\
26\end{array}$ & None & $\begin{array}{l}\text { Uncertain prognosis; } \\
\text { resul ts may have } \\
\text { been compromised by } \\
\text { inadvertent exposure } \\
\text { of astronauts to } \\
\text { toxic gases during } \\
\text { recovery. }\end{array}$ \\
\hline & $\begin{array}{l}\text { Serum Gluta- } \\
\text { mic Oxalace- } \\
\text { tic Trans- } \\
\text { aminase }\end{array}$ & $\begin{array}{l}\text { Proteiz } \\
\text { metabolism; } \\
\text { stress: } \\
\text { injury }\end{array}$ & $\begin{array}{l}\text { Eveluation of } \\
\text { well-being }\end{array}$ & $\begin{array}{l}\text { Increasedi } \\
\text { in trree } \\
\text { krewnen }\end{array}$ & $N / A$ & & $>28$ days & ASTP & $\begin{array}{l}\text { Leach } \\
26\end{array}$ & None & $\cdot$ \\
\hline & $\begin{array}{l}\text { Serum Gluta- } \\
\text { mic Pyruvic } \\
\text { Transaminase }\end{array}$ & 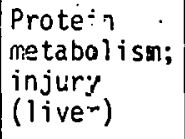 & $\begin{array}{l}\text { Evaluazion of } \\
\text { well-being }\end{array}$ & $\begin{array}{l}\text { Increased } \\
\text { in thres } \\
\text { Erewinen }\end{array}$ & $M / A$ & & $>28$ days & ASTF & $\begin{array}{l}\text { Leach } \\
26\end{array}$ & None & \\
\hline & $\begin{array}{l}\text { Biood Urea } \\
\text { Nitrogen }\end{array}$ & $\begin{array}{l}\text { Protein } \\
\text { metabolism }\end{array}$ & $\begin{array}{l}\text { Eveluation of } \\
\text { well-being }\end{array}$ & $\begin{array}{l}\text { Increased } \\
\text { in three } \\
\text { erewner. }\end{array}$ & $N / A$ & & $>28$ days & AST? & $\begin{array}{l}\text { Leach } \\
26\end{array}$ & None & \\
\hline & Uric ficid & $\begin{array}{l}\text { Nucleic acic } \\
\text { and protein } \\
\text { metabolism }\end{array}$ & $\begin{array}{l}\text { Evaluation of } \\
\text { well-being }\end{array}$ & $\begin{array}{l}\text { pecreased } \\
\text { in -wo } \\
\text { ereame? }\end{array}$ & $N / A$ & & $<28$ days & ASTP & $\begin{array}{l}\text { Leach } \\
26\end{array}$ & None & . \\
\hline & $\begin{array}{l}\text { Alkal ine } \\
\text { Phosphatase }\end{array}$ & $\begin{array}{l}\text { Stress; } \\
\text { injury } \\
(1 \mathrm{i} v=r)\end{array}$ & $\begin{array}{l}\text { Evaluation of } \\
\text { rell-teing }\end{array}$ & $\begin{array}{l}\text { Increas } 3 c \\
\text { in envo } \\
\text { frevmen: }\end{array}$ & $N / A$ & & $<28$ days & AS:P & $\begin{array}{l}\text { Leach } \\
26\end{array}$ & None & \\
\hline & Calcium & $\begin{array}{l}\text { Homeostasis } \\
\text { (esf- bone) }\end{array}$ & $\begin{array}{l}\text { Evaluation of } \\
\text { veli-seing }\end{array}$ & $\begin{array}{l}\text { Increased } \\
\text { in two } \\
\text { ereworer }\end{array}$ & $N / A$ & & $>28$ days & ASTP & $\begin{array}{l}\text { Leach } \\
26\end{array}$ & None & . \\
\hline & Magnesium & $\begin{array}{l}\text { Homejstas is } \\
\text { (esp. bone) }\end{array}$ & $\begin{array}{l}\text { Evaluation of } \\
\text { well-being }\end{array}$ & $\begin{array}{l}\text { pecreased } \\
\text { in one } \\
\text { Er wwma: }\end{array}$ & $N / A$ & & $<28$ days & ASTP & $\begin{array}{l}\text { Leach } \\
26\end{array}$ & None & \\
\hline & Phosphate & $\begin{array}{l}\text { Homeostas is } \\
\text { (esp. Lone) }\end{array}$ & $\begin{array}{l}\text { Evaluation of } \\
\text { well-being }\end{array}$ & $\begin{array}{l}\text { Proreased } \\
\text { ir: ore, } \\
\text { decreased } \\
\text { pr: one } \\
\text { prewacn }\end{array}$ & N/A & & $<28$ days & AITP & $\begin{array}{l}\text { Leach } \\
26\end{array}$ & None & \\
\hline & $\begin{array}{l}\text { Total } \\
\text { Bilirubin }\end{array}$ & $\begin{array}{l}\text { Heroglobin } \\
\text { destruction }\end{array}$ & $\begin{array}{l}\text { Evaluation of } \\
\text { well-being }\end{array}$ & $\begin{array}{l}\text { pecraased } \\
\text { in th'ee } \\
\text { grewmen }\end{array}$ & $N / \beta$ & & $>28$ days & ASTP & $\begin{array}{l}\text { Leach } \\
26\end{array}$ & None & $\downarrow$ \\
\hline
\end{tabular}


INVENTORY OF HUMAN RESPONSES TO SPACE FLIGHT

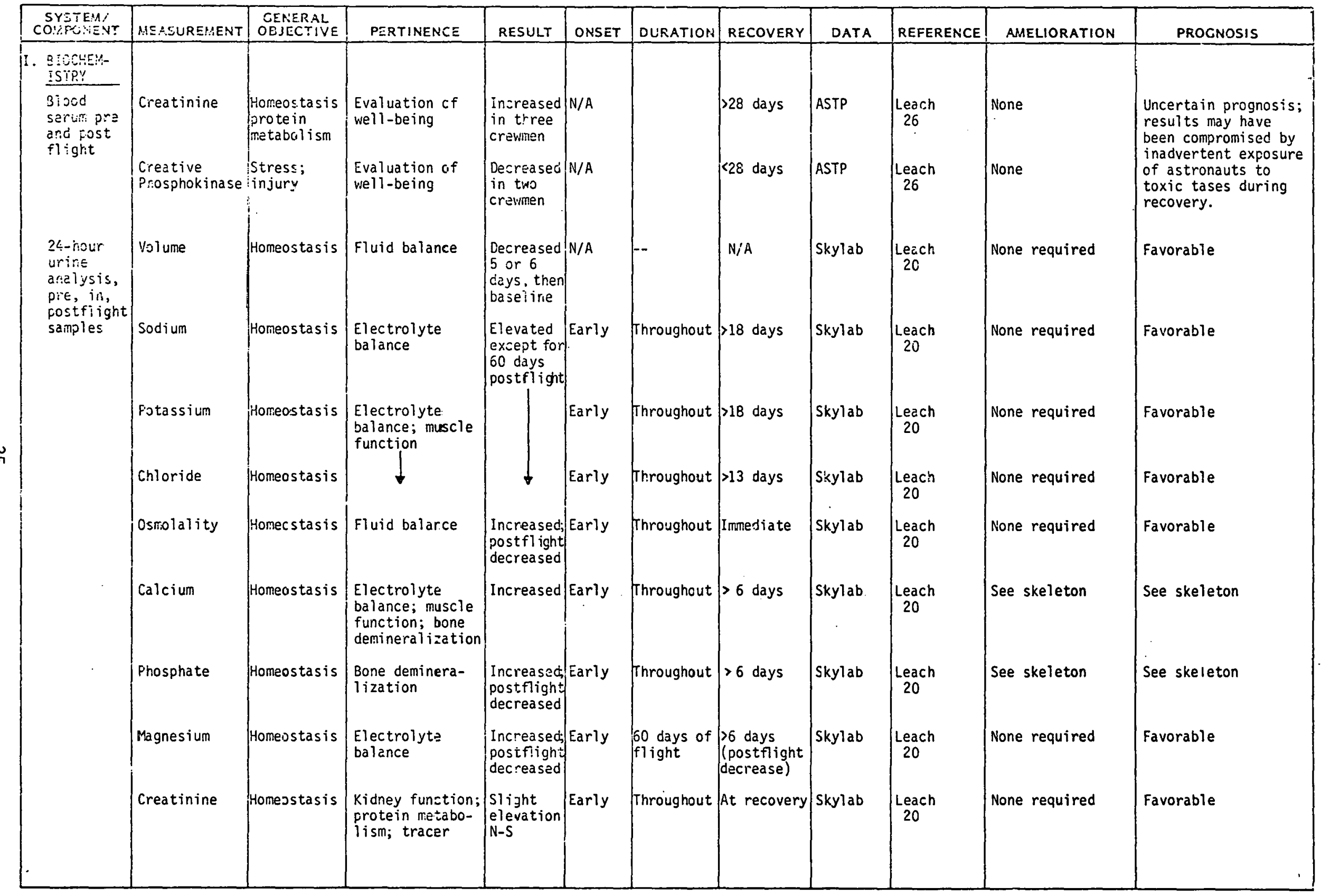


INVENTORY GF HUBAN RESPONSES TO SPACE FIIGHT

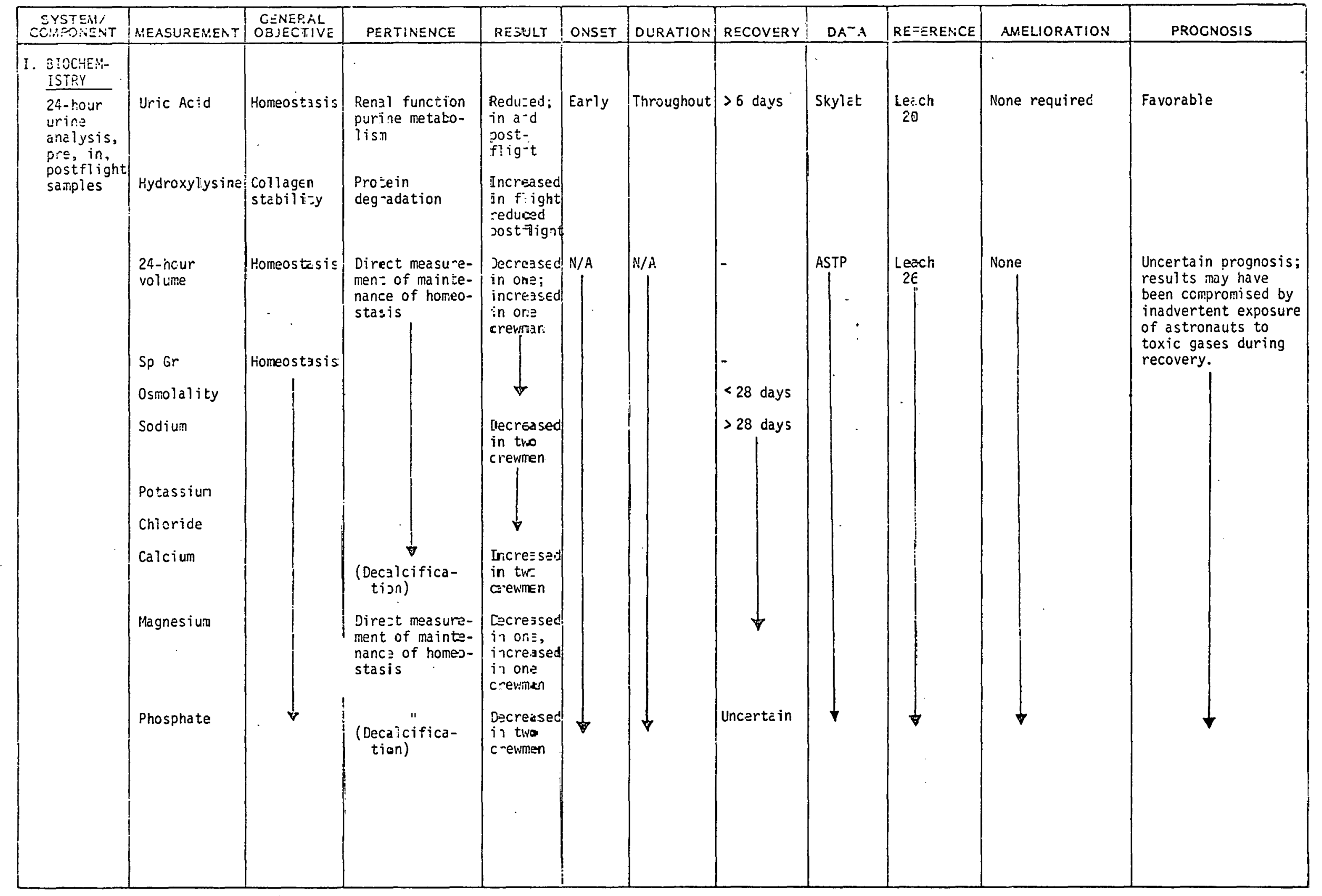


INVENTORY OF HUMAN RESPONSES TO SPACE FLIGHT

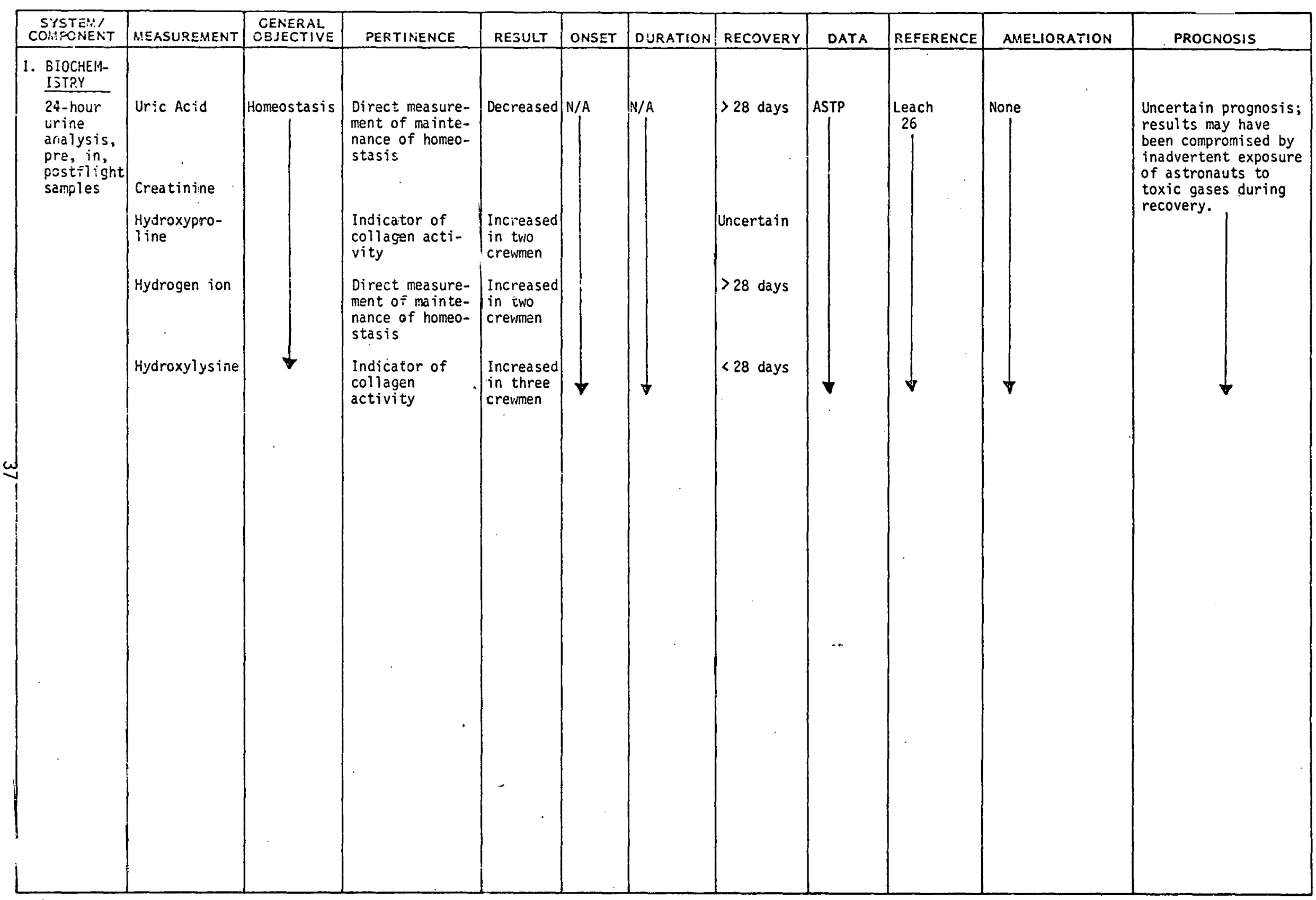


INVENTORY OF HUMAN RESPONSES TO SPACE FLIGHT

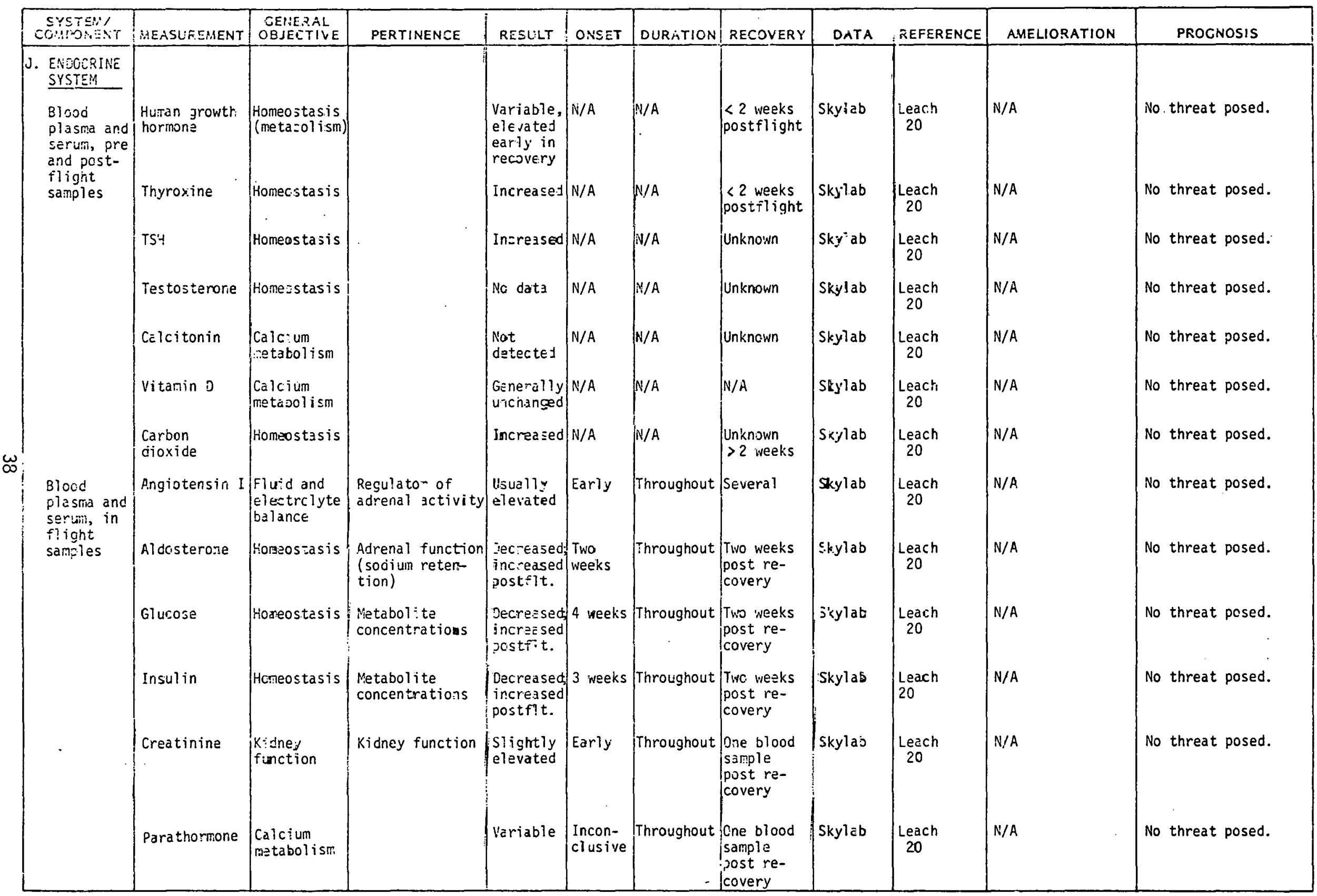


INVENTORY OF HUMAN RESPONSES TO SPACE FLIGHT

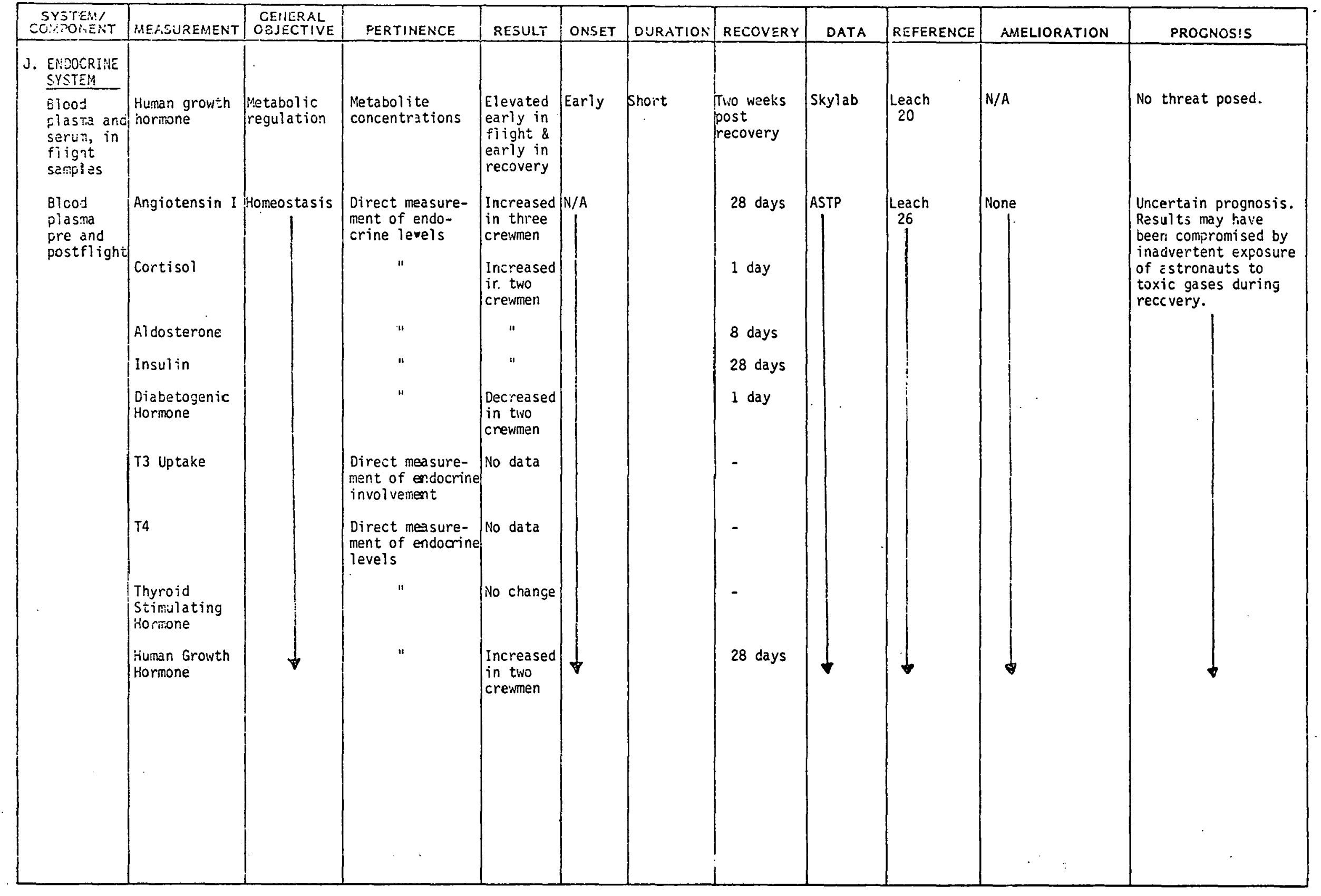


INVENTORY OF HUMAN RESPONSES TO SPACE FLIGHT

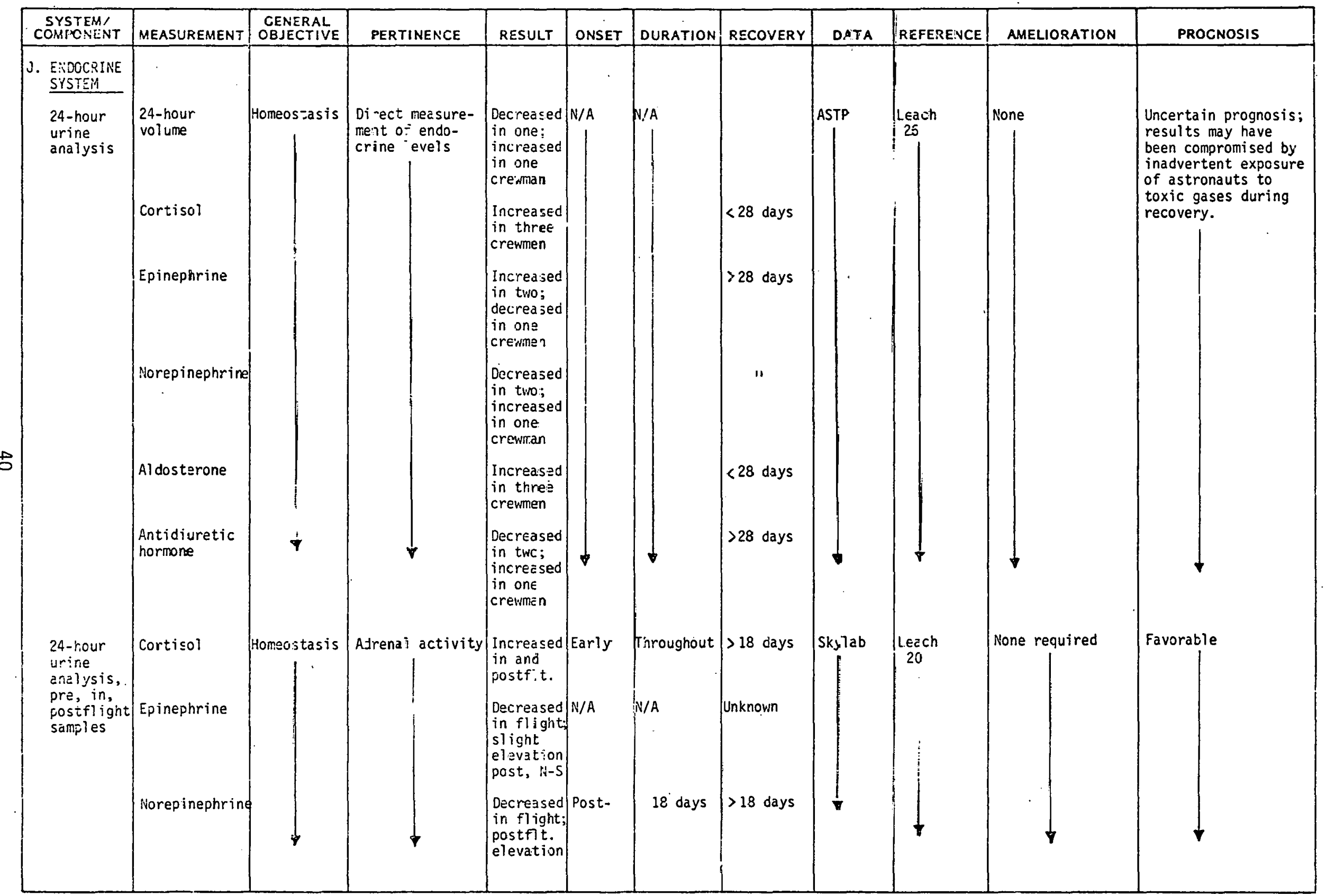


INIVENTORY OF HUMAN RESPONSES TO SPACE FLIGHT

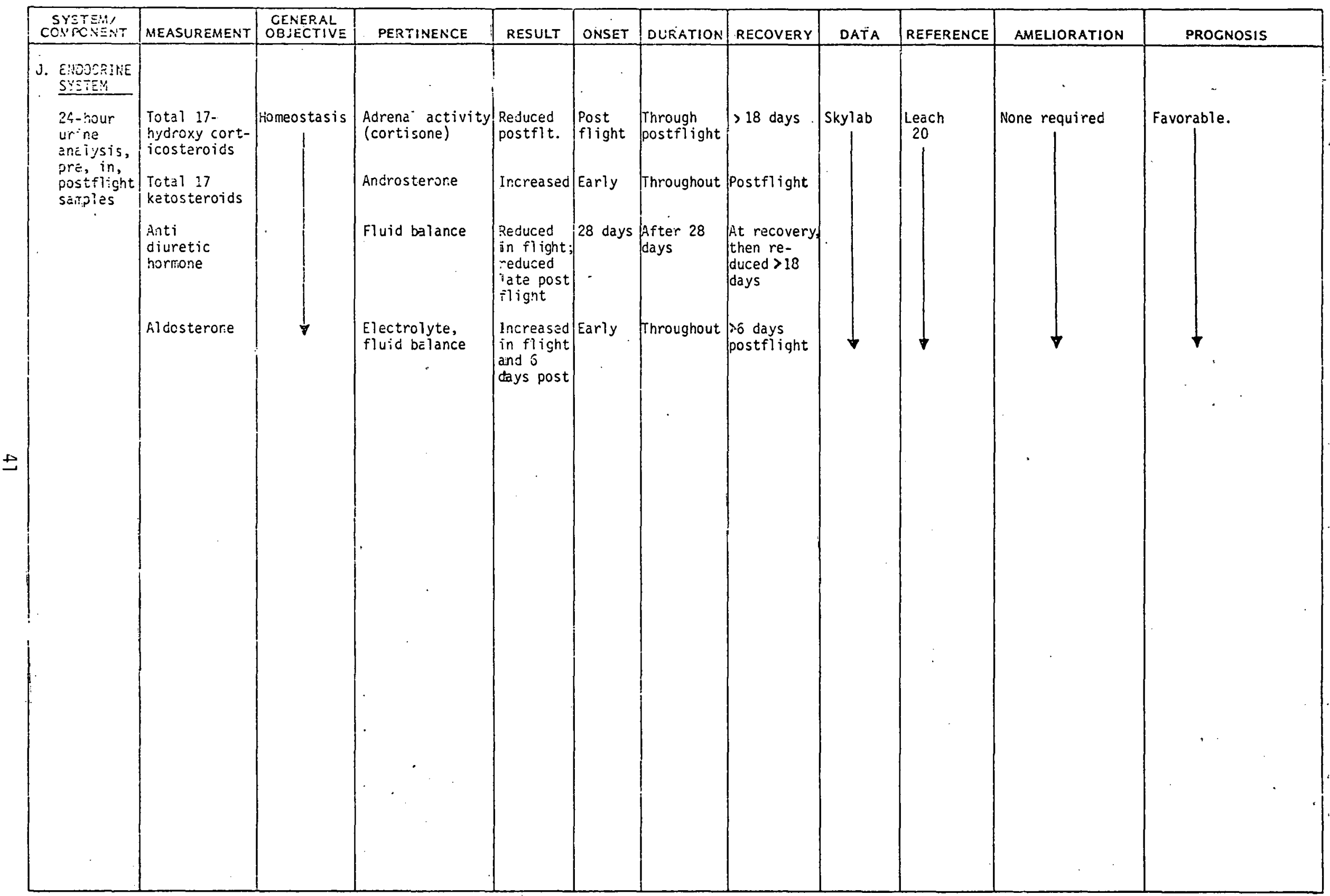


INVENTORY DF HUMAN RESPONSES TO SPACE FLIGHT

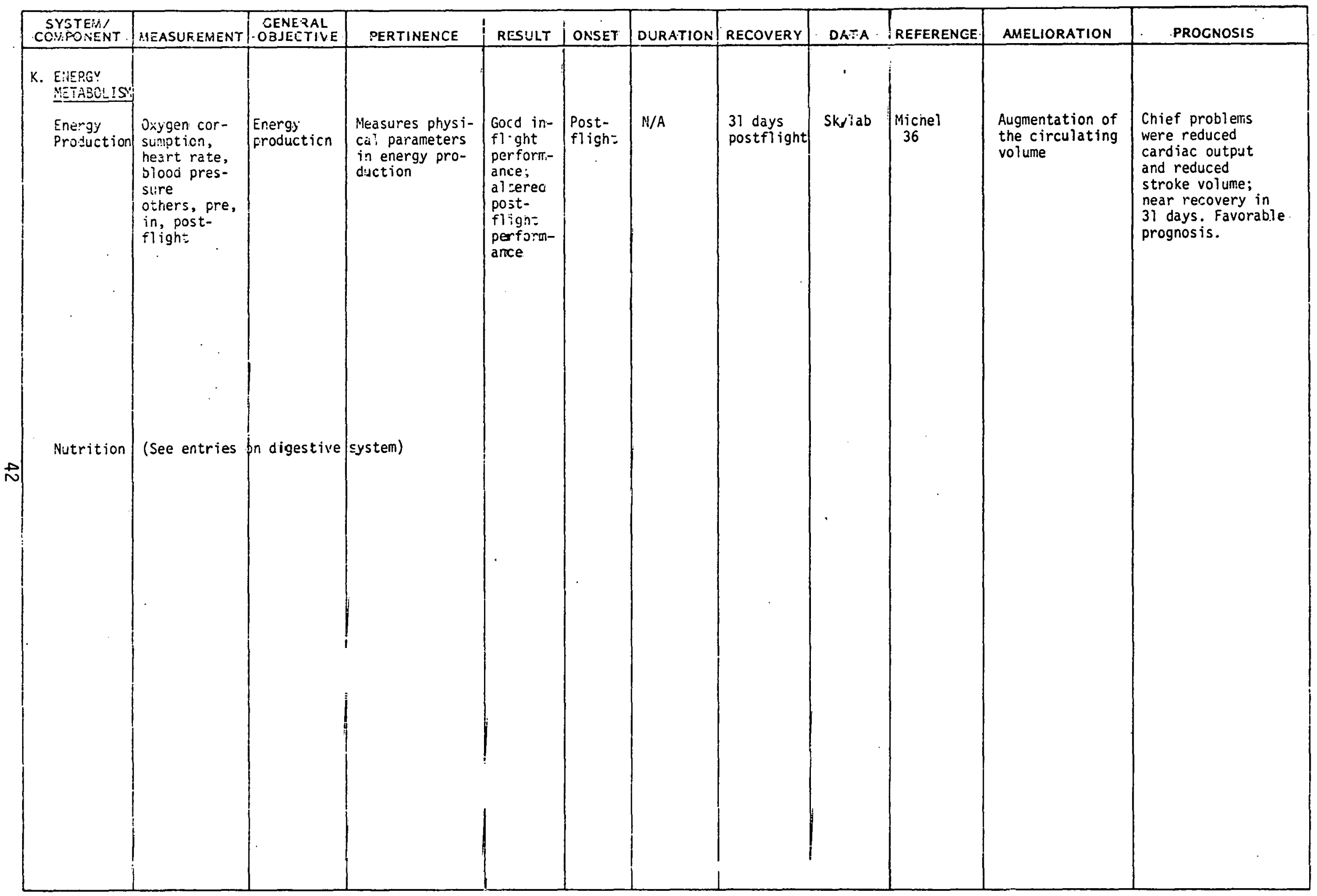


INVENTORY OF HUMAN RESPONSES TO SPACE FLIGHT

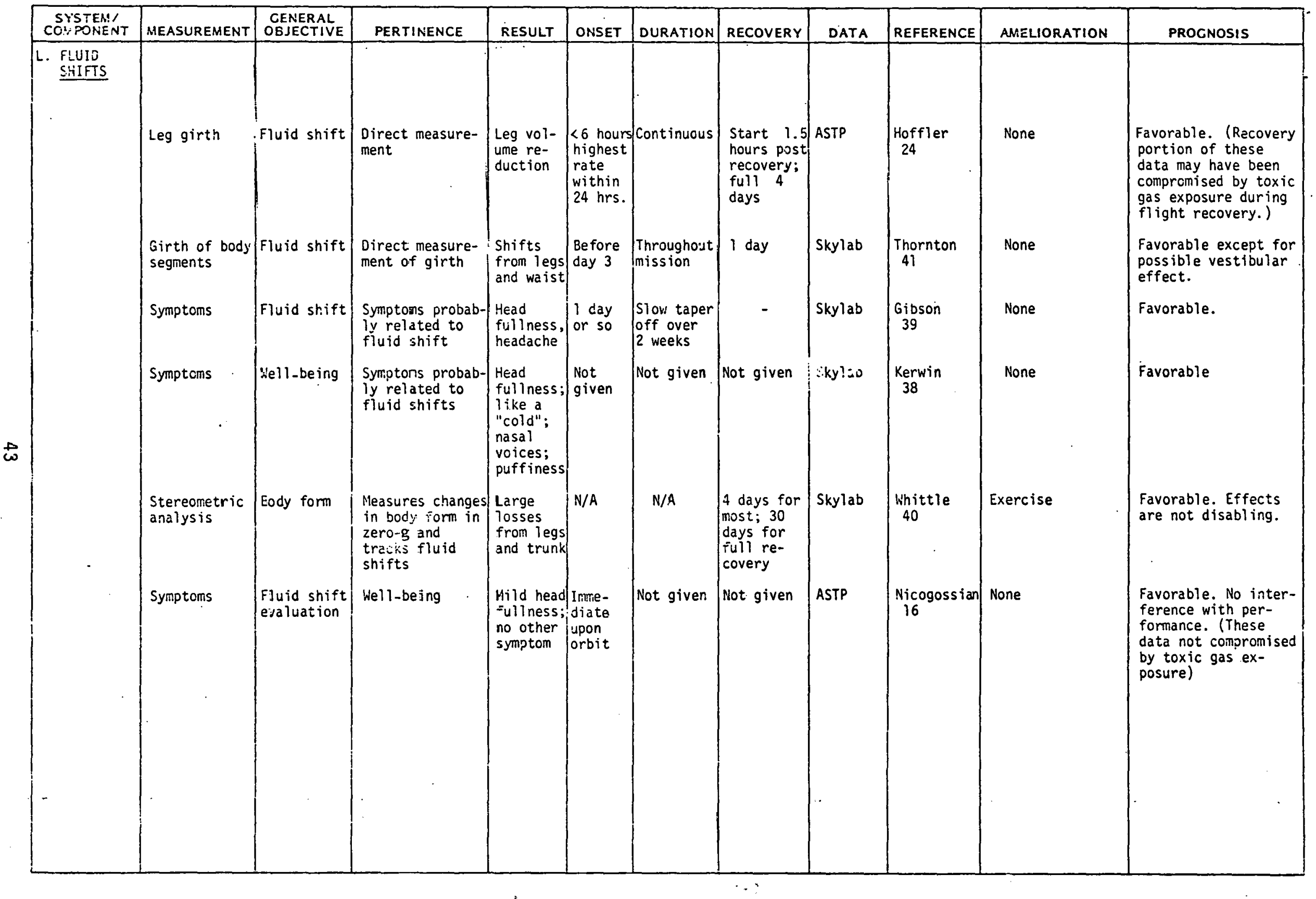


INUENTORY JF HUMAN RESPONSES TO SPACE FLIGHT

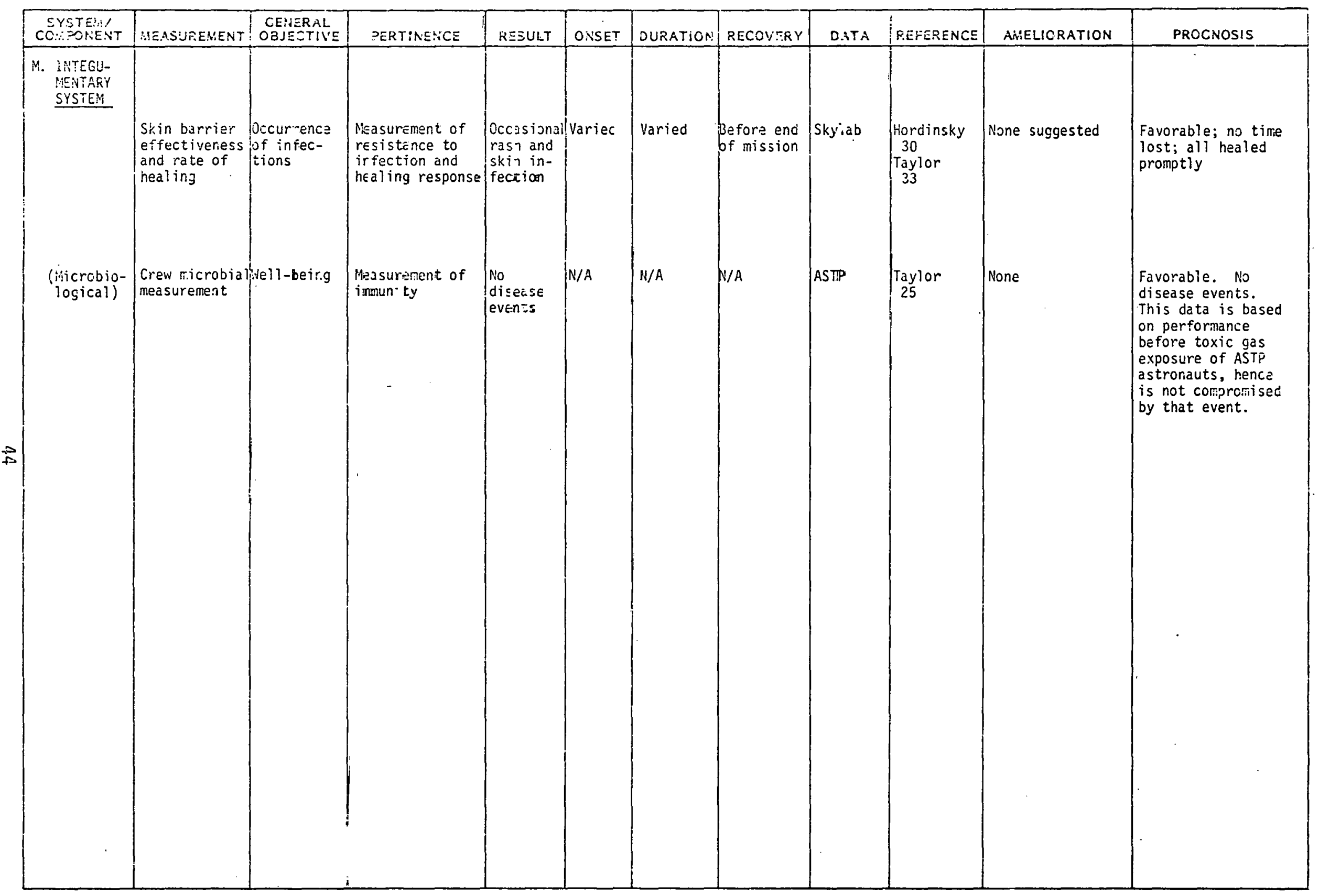


INVENTORY OF HUMAN RESPONSES TO SPACE FLIGHT

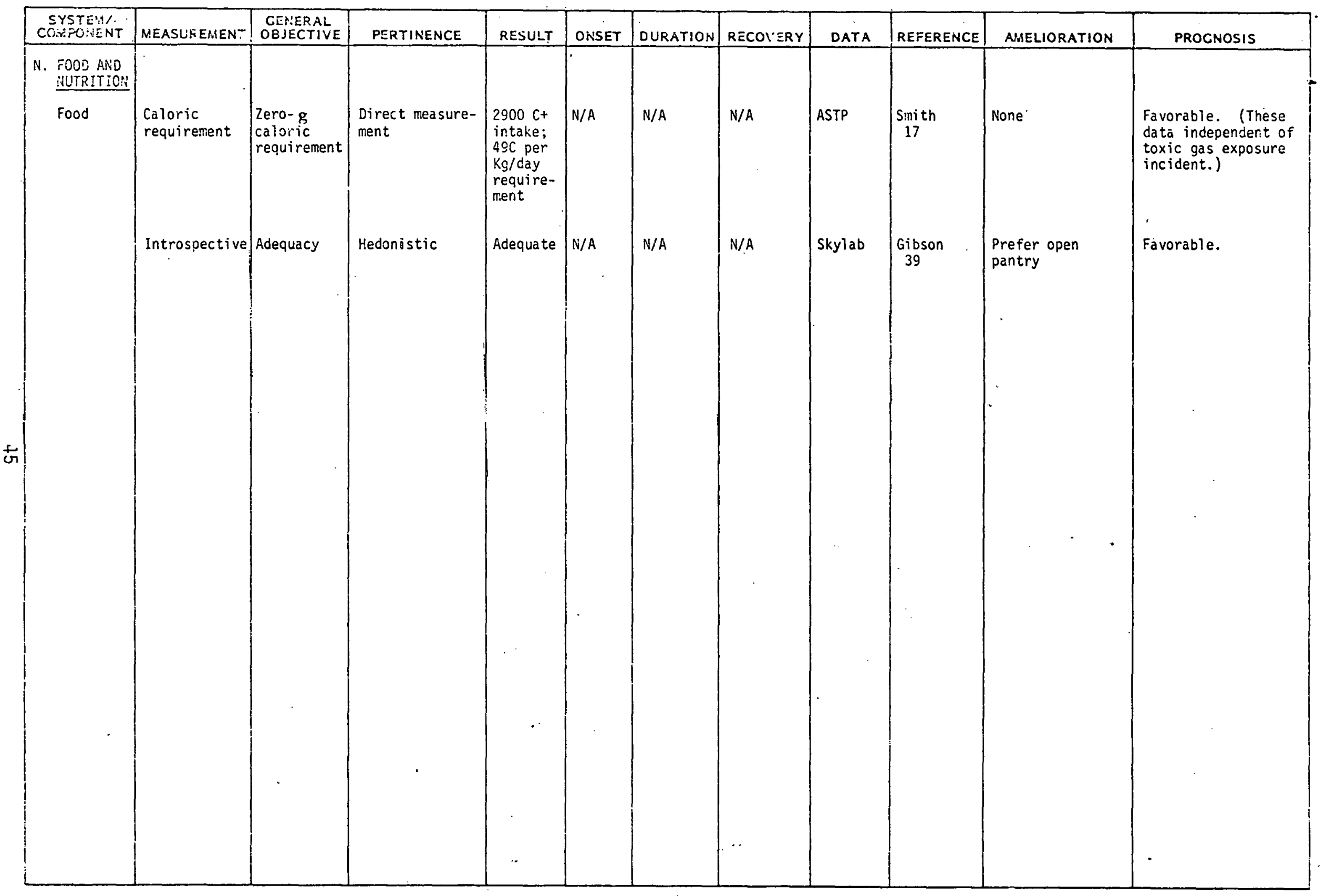


INVENTORY OF HUWAN RESPONSES TO SPACE FLIGHT

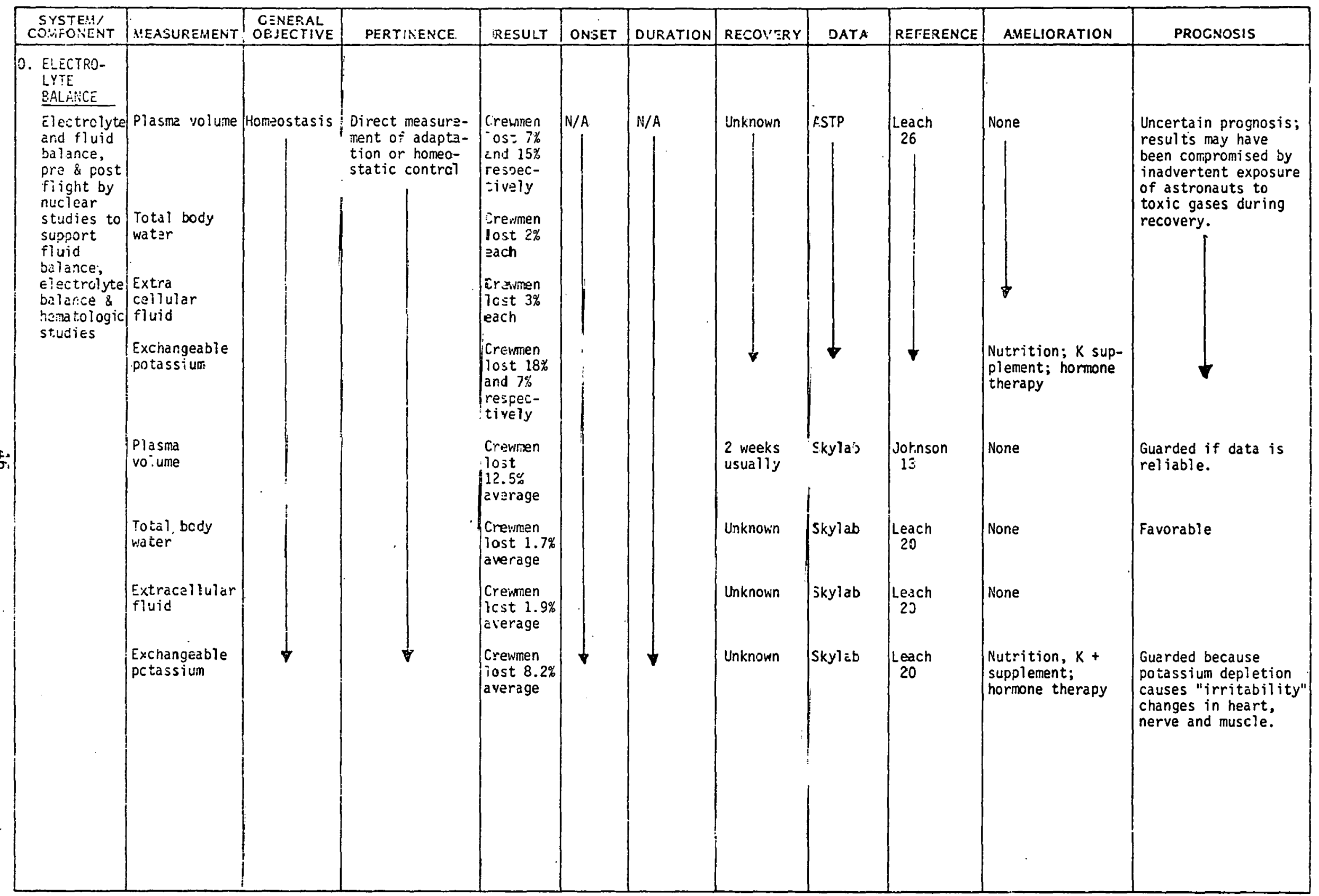


IV. DISCUSSION OF HUMAN RESPONSES TO SPACE FLIGHT

This section contains discussions relating to the responses of humans to weightlessness, acceleration/deceleration and other elements of space flight which may affect the heal th and safety of SPS space workers.

\section{A. WEIGHTLESSNESS}

The weightless environment of space flight has been available for scientific investigation only since the early 1960's. The ability or inability of the human physiological system to adapt to this unique environment and subsequently to readapt to a one-g environment may ultimately limit the duration of manned space flights. This section contains a description of the general physiological effects of weightlessness, with emphasis on the physiological effects that could limit mission durations in the absence of effective countermeasures and with special reference to mission operations. Whenever morphological changes follow their physiological counterparts, the implications are discussed.

Research programs at NASA are carried out by many teams of investigators who utilize different approaches and methods in studying facets of the overall problems. Whenever possible, this section will attempt to unify the various research results and to present a composite picture or status of test results for each organ system or physiological function.

\section{Definition}

When the inertial forces of an orbiting body exactly balance the gravitational forces, the resultant forces impinging on the body have a magnitude of zero. This state is referred zero-g, null gravity, or weightlessness.

It is only during space flight that weightlessness is produced for any extended period. However, the zero-g state can be produced for brief periods within the Earth's atmosphere. Aircraft flying a Keplerian parabolic trajectory have produced periods of weightlessness for as long as 60 seconds (54). These brief periods of zero-g have 1 imited usefulness for investigations of 
the physiological effects of weightlessness; they are most useful for developing and evaluating space-flight hardware and procedures. Other available methods by which certain effects of the weightless environment on living systems can be simulated more or less realistically depend on the phenomenon being observed. Bed rest and liquid immersion have been used for may years to simulate the effects of space flight on the human musculoskeletal, cardiovascular, fluid, hormonal and electrolyte control systems. These analogs of weightlessness provide an opportunity to test hypotheses, explore mechanisms, and evaluate countermeasures in areas where physiological effects similar to those observed in zero-g are know to occur.

Weightlessness is known to affect several physiological systems including musculoskeletal, cardiovascular; humoral, vestibular, hormonal and electrolyte contrul. Many of the changes are not fully realized until return to the one-g environment.

Gravitational forces have been present in the evolutionary development of every species of 1 and animal and plant. The anatomical placement and mass of the skeleton and musculature of land animals have subsequently evolved to maintain posture and provide locomotion against these gravitational forces.

To enable man and other animals to acquire and maintain posture and body orientation in normal gravity, the central nervous system interprets visual, kinesthetic, vestibular, and statokinetic signals to produce the "appropriate" gravity-dependent sensorimotor response. Both the mechanicoreceptors within the body and the learned central nervous system interpretations are turned to the terrestrial weight/force relationship. Further, the cardiovascular system of man and of other aninals have evolved anatomical structures and physiological mechanisms (e.g., cartoid sinus reflex) to overcome changes or orientation with respect to gravitational forces.

In essence, the "stress" of weightlessness is the removal of forces to which the body is adapted and for which the body is genetically designed to counteract. Adaptation to the weightless environment involves disuse or modified use of these structures and mechanisms. Rapid and complete adaptation to a weightless environment is desirable for enhanced performance during space 
flight. However, the degree of adaptation during weightless exposure may affect the severity of problems encountered upon return and readaptation to the one-g environment.

The weightlessness of the space environment applies predictable stresses in selective modes to human subjects and results in fairly predictable responses. A number of these responses appear to be either deleterious to the continued health and well-being of anyone while in space, particularly over protracted periods, or somewhat prejudicial or disabling to anyone during and immediately after return to a gravity-based earth existence. At least one response, loss of structural integrity of bone, may not be fully reversed for several months.

The organ systems and functions recognized as sensitive to the changes to and from weightlessness are the mu. oskeletal system, the cardiovascular system, the immune system, the ende: system (secondarily), and bioenergetic control.

The organ systems that have suffered minimal or no measurable functional changes during space exposure include:

Reproductivce

Digestive

Respiratory (in zero acceleration)

Lymphatic

Nervous (especially psychomotor, behavior, judgement, problem-solving ability)

Excretory

Sensory (except vestibuiar)

Responses are classified as gross-level effects and less important effects.

\section{Gross-Level Effects}

Antigravity muscle mass loss, is probably comprised of fluid surrounding the muscle fibers and protein from the muscle fibers themselves. Other skeletal muscles exhibit these losses to a lesser degree. There is a small, reversible loss of strength and ability to perform work at maximal levels. 
Skeletal intergrity is compromised by slow losses of the protein matrix of bone as well as of bone mineral, leading toward osteoporosis. Recovery is known to require a protracted period.

There is a fluid shift, particularly from the legs to the head and upper torso, and some fluid is lost, probably from the blood plasma primarily with some contribution of interstitial fluids from leg musculature. The fluid shift to the upper regions causes engorgement of veins, puffiness of distensible regions of the face and neck, and sinus and oropharyngeal congestion. These changes possibly contribute to the development of untoward vestibular responses including nausea and vomiting.

Cardiovascular adaptability or competence (orthostatic tolerance) is compromised by weightlessness. This finding is demonstrated by stress tests including lower body negative pressure (LBNP) upon return to an erect posture in normogravity following space exposure.

\section{Less Important Effects}

Less obvious changes that may be secondary or tertiary level effects include:

Skin infections which might be a result of defense system change or depression, inadequacy of provisions for maintaining hygiene, increased virulence of microbial invaders, or other cause.

A loss of red cell mass, probably related to depression of hemopoietic capabilities.

Changes in neuroendocrine activity as measured in blood and urine specimens, with especial reference to electrolyte and water balance, electrolyte losses and plasma volume loss.

Physical injury produced by an inflexible or poorly fitting space garment after the subject has experienced spinal elongation on other anthropometric changes in null gravity. 
Reduced sensory accuity or discrimination have been reported by some Apollo and Skylab astronauts. These have been manifest as a reported inability to taste spices in foods. Diminution in ability to smell due to engorgement of mucous membranes in the head and/or the lack of normal convection currents may contribute to this condition.

A catch-all category that produces the readout that bioenergetic control has been compromised; maximal work performance capability is reduced and the calibratable responses among energy output, heart rate and oxygen uptake lose their quantitative interdependence.

Musculoskeletal system

Reduction of extermal forces acting on the weight-bearing structure of the body results in loss of calcium and other minerals important to bone integrity. Animals reared on a centrifuge where they are exposed to elevated $g$ loadings develop enlarged skeletal members. Human inactivity such as bed rest" causes some members of the skeleton to lose mineral and leads to decreased density and increased brittleness of bone. The skeletal response appl fed load is described by Wolff's 1 aw as a linear one, hence there is assurance that a program to stress the skeleton should prevent demineralization. Also a host of factors that influence mineralization can be manipulated; e.g., vitamin D, calcitonin, parathormone, calcium, phosphorus, and nutritional requirements. Androgenic hormones might al so be involved. However, means that have been tested in bed rest and in space have met with little success - calcium loss has continued throughout the longest space missions to date, 175 days (Soviet data).

Three of the Skylab crewmen exhibited loss of os calcis (heel bone) material, and none showed an loss from the arm skeleton. One had regained bone loss by the 87 th day postfi ight, and the other two had not regained their losses by the 95th day. Losses were correlated with urinary hydroxyproline excretion which is thought to be an Indication of bone matrix (protein) loss.

Urinary calcium excretion was high in all Skylab crewmen. As expected, fecal calcium excretion was greater than urinary calcium. The rate did not subside. of particular note is the observation that whereas excretion of calcium in 
urine reached a plateau (twice or more than nomal at 1-G), the amount of calcium in the feces continued to increase for the full 84 days in all three astronauts of the SL-4 mission. The average loss from the heel bone was about 3.9\% per month. Phosphorus loss was similar. Urinary calcium and phosphorus excretion had returned to normal in less than one week postflight, but bone structure had not been rebuilt. As noted above, upwards of three months were required for bone resynthesis. The loss was of no immediate concern, but it has a great deal of potential significance for long duration missions because the loss of total body calcium was about $0.4 \%$ per month.

Skeletal stress is normally produced by the action of gravity and by muscular force. In space, without apparent gravity, exercise from 30 minutes per day on Skylab 2 to 90 minutes per day on Skylab 4 did not prevent calcium excretion and bone demineralization. Soviet experfence on Salyut 6 which involved exercise for periods of up to 150 minutes per day on fights to 175 days was similar in that bone loss continued. There is reason to expect that a novel exercise program can be synthesized that will more nearly duplicate the natural loads on the skeleton and maintain skeletal integrity, perhaps when augemented by nutritional factors, drugs, longitudinal compression of skeletal members, or other techniques short of providing artificial gravity.

Intractubility of the demineralization phenomenon suggests that a part of the rausation has not been considered. Perhaps a sensor 1 s causing inappropriate decalcification, mobilizing calcium to meet an electrulyle bảalice requirement, while another part of the control systell is causing the calcium to be excreted. If this is true, then loading calcium in the intake should suppress demineralization and urinary calcium. However, in bed rest studies loading calcium does not suppress urinary calcium; it appears to suppress demineralization for a time (up to 3 months) but then decreased intestinal absorption becomes so great that balance goes negative.

Without remedial measures, missions of 8 to 9 months would not be precluded, based on our present understanding of skeletal dynamics in welghtlessness. Very lengthy missions would be precluded because of our belief that serlous degradation to trabecular bone represents a morphological change that cannot be corrected. 
During hypodynamic conditions such as bed rest, muscle size and strength are reduced. The resulting atrophy can be followed by measurement of excess nitrogenous compounds in the urine and by reduction in muscle volume. The musculature most affected is that involved in countering gravity, primarily in the legs. The most significant way to maintain musculature (tonus, strength, endurance) is to maintain a level of exercise which will prevent any loss of or change on the physiological properties of muscle. It is generally assumed that a properly designed exercise program will also result in sufficient skeletal stress to maintain the skeleton in prime condition, but the results from bed rest and space tests have thus far been disappointing.

The loss of nitrogen, both in increase in urinary nitrogen and by balance study (which takes into account the dietary protein intake) was significant; distinctly greater than previously noted in any bed rest study, and it continued for the full length of the Skylab flights.

In Skylab, there was no loss in work capacity. Muscular strength was slightly reduced. During postflight testing, work capacity was severely reduced, but the reduction was attributed to reduced cardiac output.

There was loss of nitrogen, indicating a loss in muscle mass which was also confinmed by measuring limb girth and by biostereometrics. The degree of atrophy is speculative as the fluid shift adds uncertainty to the interpretation of volume measurements. One investigator suggested the figure of $300 \mathrm{ml}$ for muscle atrophy in Skylab astronauts, based on recovery kinetics.

Calculations of muscle tissue loss from nitrogen balance data indicated much greater muscle atrophy. These data indicate a mean muscle tissue loss among the three Skylab-4 astronauts of $1.9 \mathrm{~kg}$. In recovery on Earth, there was a sharp drop in urinary nitrogen, to well below pre-flight levels, consistent with rebuilding of muscle tissue.

Postflight electromyographic studies on Skylab and the ASTP program showed muscle superexcitability and increased fatigability along with reduced tension capabiltiy. The ASTP data al so showed increased electrical efficiency of arm muscles and decreased electrical efficicncy of leg muscles. 
Changes in size and electromyographic properties of muscle after prolonged space flight indicate that absolute muscular integrity has not been achieved by exercise. The experience of $S k y l a b-4$ indicated that there should be no concern for operational performance in stays of 90 days; from the continuation of increased urinary nitrogen excretion throughout flight, however, the duration of "no concern" beyond 90 days is uncertain, even with an exercise program.

Cardiovascular system

Hemodynamic.s

The normal or customary human tolerance to the stress. of upright posture in one-g (orthostatic tolerance) is temporarily reduced after space flight. This is manifested subjectively by symptoms presaging syncope (faint-headedness, dizziness, weakness, transient instability upon standing) and objectively by test signs and cardiovascular measurements (increased heart rate, decreased pulse pressure, presyncope). The fairly consistent finding of a $10 \% 10$ ss in plasma volume after space flight may be a contributory factor in the development of orthostatic intolerance. Signs and symptoms may persist for up to one to two weeks after flight without a discrete mission duration dependency. A special concern arises when accelerative (decelerative) forces upon the long axis of the body $\left(+G_{z}\right)$ are applied during crucial tasks, e.g., on reentry. To prevent tolerance from being exceeded, a cardiovascular counter pressure garment was worn to provide mechanical counterpressure to the lower extremeties to reduce the postural hypotension of effects following 1 anding and operations under one-g conditions.

No specific inflight operational problems are known that have a cardiovascular origin. A headward fluid shift may degrade perfomance, at least carly upon attaining orbit, by virtue of reported feeling of malaise, headache, sinus congeslion, and a sensition of head fullness.

Exercise capacity is moderately and transiently reduced postfi ight but appears well maintained inflight. The current hypothesis relates this postflight decrement in exercise capacity causally to the same mechanisms involved in reduced orthostatic tolerance. 
Blood and fluid redistributions such that the heart does not fill normally seem to be at the core of the total phenomenon of orthostatic intoleranc. It is conceivable that early inflight space sickness may be causally related. Alterations observed in inflight electrocardiograms are al so probably directly related to cephalad fluid shifts.

Measurement of electromechanical properties of the heart postflight against a preflight baseline in both resting and stress condition revealed changes in systolic time intervals and reduced amplitude of the first heart sound. Recovery to preflight baseline required less than 31 days postflight, but the capability for maximum levels of exercise was depressed for perhaps two months.

Measurement of cardiac electrical parameters by vectorcardiography, and pre-, in- and postflight with ergometer and LBNP stress, revealed minor changes between resting values, pre- and postflight. Lower body negative pressure stress added to the changes. The most unfavorable responses to the LBNP stress diminished after five to seven weeks of flight. There were small changes except at recovery when low cardiac output compromised exercise capability. The changes during flight included increased ORS vector magnitude and reduced heart rate and response to exercise compared to preflight. The unfavorable responses to LBNP inflight and to exercise postflight were presyncopal in nature and of sufficient severity to cause early termination of test protocols. It should be noted that these failed protocols stem form inadequate venous return and consequent reduced cardiac output; the heart itself is not necessarily implicated.

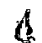

The effect of the reappearance of hydrostatic forces due to reentry accelerations may accentuate the effects of an inadequate circulating blood volume after even a few days in space. Skylab experience indicates that adequate protection against orthostatic hypotension during reentry and during the first few hours after flight can be provided by a counterpressure garment. This countermeasure is indicated during any significant exposure to $+G z$ accelerations, as will be experienced by SPS crewmen ${ }^{1}$. Recumbency can be of further

\footnotetext{
The effects of acceleration/deceleration is discussed in section $B$.
} 
benefit during the first few hours after flight in cushioning the cardiovascu1 ar effects of return to one-g by preventing large shifts of intravascular fluids to the lower extremity vessels and extravascular compartments.

X-ray determinations of the cardiac area showed reduced dimensions postflight; attributed to either a loss of cardiac mass or a deficit in volume return to the heart. Recovery trends were noted in four or five days.

Measurements of heart parameters by echocardiography showed that the myocardium has lost mass in postflight measurements when compared with the preflight baseline. There was a reduction in ventricular end diastolic volume, and a reduction in strokc volume. These parameters returned to baseline in lcss than 30 days postflight. The investigators concluded that impairments of cardiac function as a result of space flight was relatively minor and recovery of function after flight was relatively rapid.

The only physical test of vascular parameters (other than venous pressure) was of compliance; the property of vessels to expand with increases in pressure. It was found that compliance of leg vessels increased for the first several days of flight, then lessened, and returned to baseline in several days after recovery. This would appear to be a small but significant complication to other factors causing cardiovascular embarassment upon recovery.

Hema t.ol ogy

Blood studies performed in the space program included cell counts, red cell mass determinations, hemoglobins, hematocrits, plasma volume deleminations, cytologies, and studies directed to immunological competence.

Plasma volume reduction averaged 8.4 percent in $\$ k y l a b 2,13.1$ percent in Skylab 3 and 15.9 percent in Skylab 4 (see figure IV-1). The plasma volume luss may be attributed to operation of the Gauer-Henry reflex. An apparent overload of fluid causes atrial distension which causes the antidiuretic hormone (ADH) level to fall. Circulating fluid is then lost by diuresis or reduction in intake, or both (see figure IV-2). Discussion of the endocrinology depicted in figure IV -2 will be found in the sub-section entitled Endocrinology. It required approximately four weeks for $\mathrm{plasma}$ volume recovery after Skylab 2, two weeks after Skylab 3, and one week after Skylab 4. 
Red cell mass appears to be some 15 percent reduced at about 40 days from launch (see figure IV-1). The red cell mass was apparently depleted by a splenic process. After 30 to 60 days in space, it appears that regeneration of the red cell mass had been initiated, and that regeneration was nearly comlete after 84 days. The kinetics of recovery were identical whether or not the subject remained in flight, and complete recovery appeared at about day 100.

When the curves for red cell mass loss and plasma volume loss are superposed, as seen in figure IV-1, the kinetics of production of the effects and recovery are not matched; cell mass, is normal while plasma volume is at near maximum reduction. This leads to rather high hematocrit values unless it is sensed and corrected.

Examination of erythrocyte shape showed that a significant fraction (about 7 percent) of the erythrocytes had undergone shape transformations to echinocytes near the end of Skylab 4. The echinocyte stage is the end stage in a series of recognizable changes from the disc-shaped red cell to a spheroid with protuberances. Within two hours after recovery, the echinocyte level had returned to the baseline value. Shape changes were without apparent significance or handicap to the crewmember.

Polymorphonuclear leucocyte ability to adhere, migrate and phagocytize was norma1. This is a defense and clean-up process.

Immunity

Immunity entails a demonstrable level of defense against microbiological agents. Qualitative and quantitative tests are almost always performed outside the body, i.e., in vitro, with standardized reagents to show that the capability exists to repel an invader.

The only. systems tested were humoral immunity. which involved modified globulins, complement factors, several protein fractions, and B (bursa) lymphocytes which are carried in body fluids, especially the blood plasma; and cellular immunity which involves both $T$ (thymus-dependent) 1 ymphocytes and macrophages. Lymphocytes can engulf and neutralize microbiological agents. (Macrophage function is.less specific and was not tested.) .. 


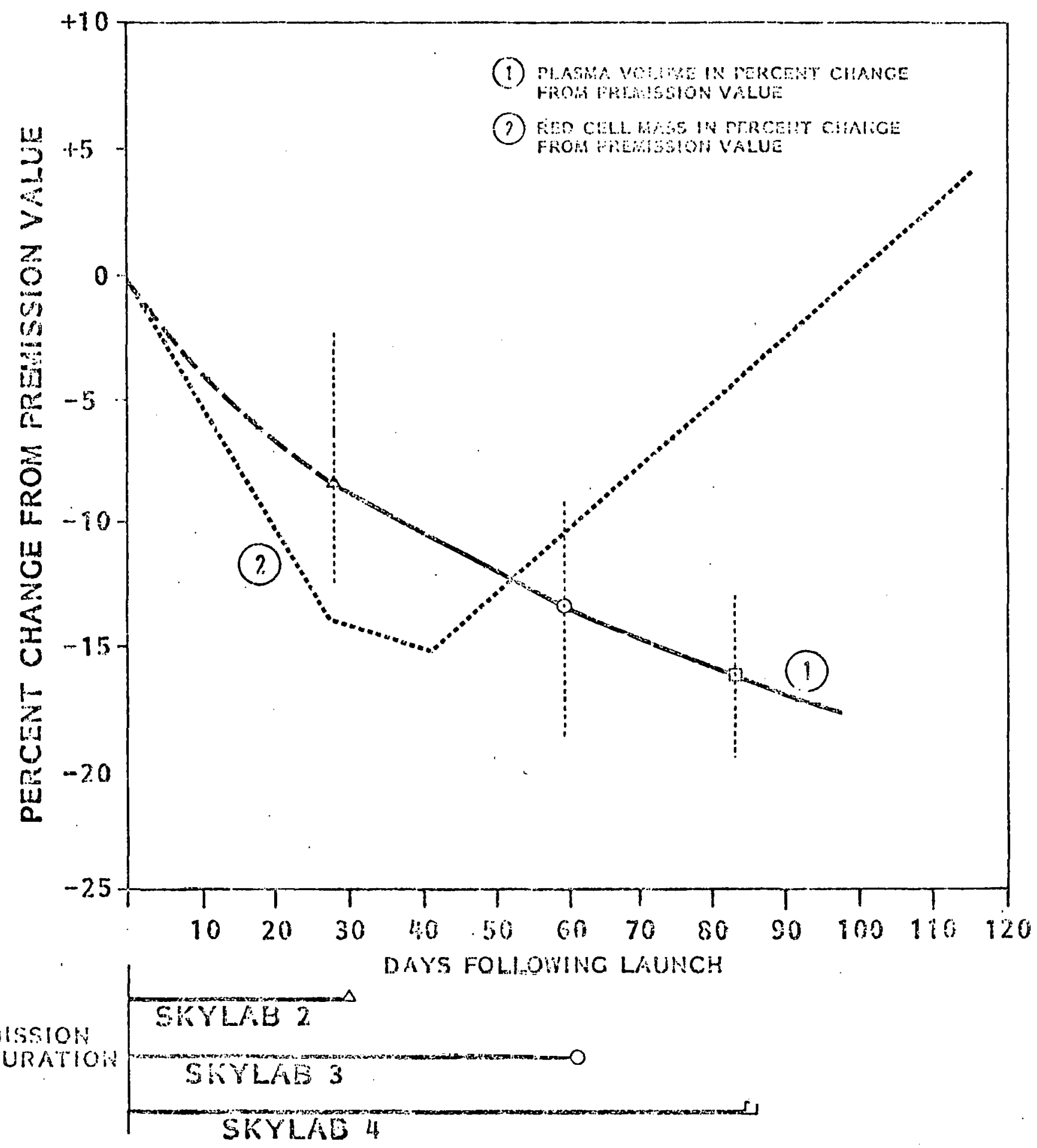

Figure IV-1. Biood volume changes in Skylab. 


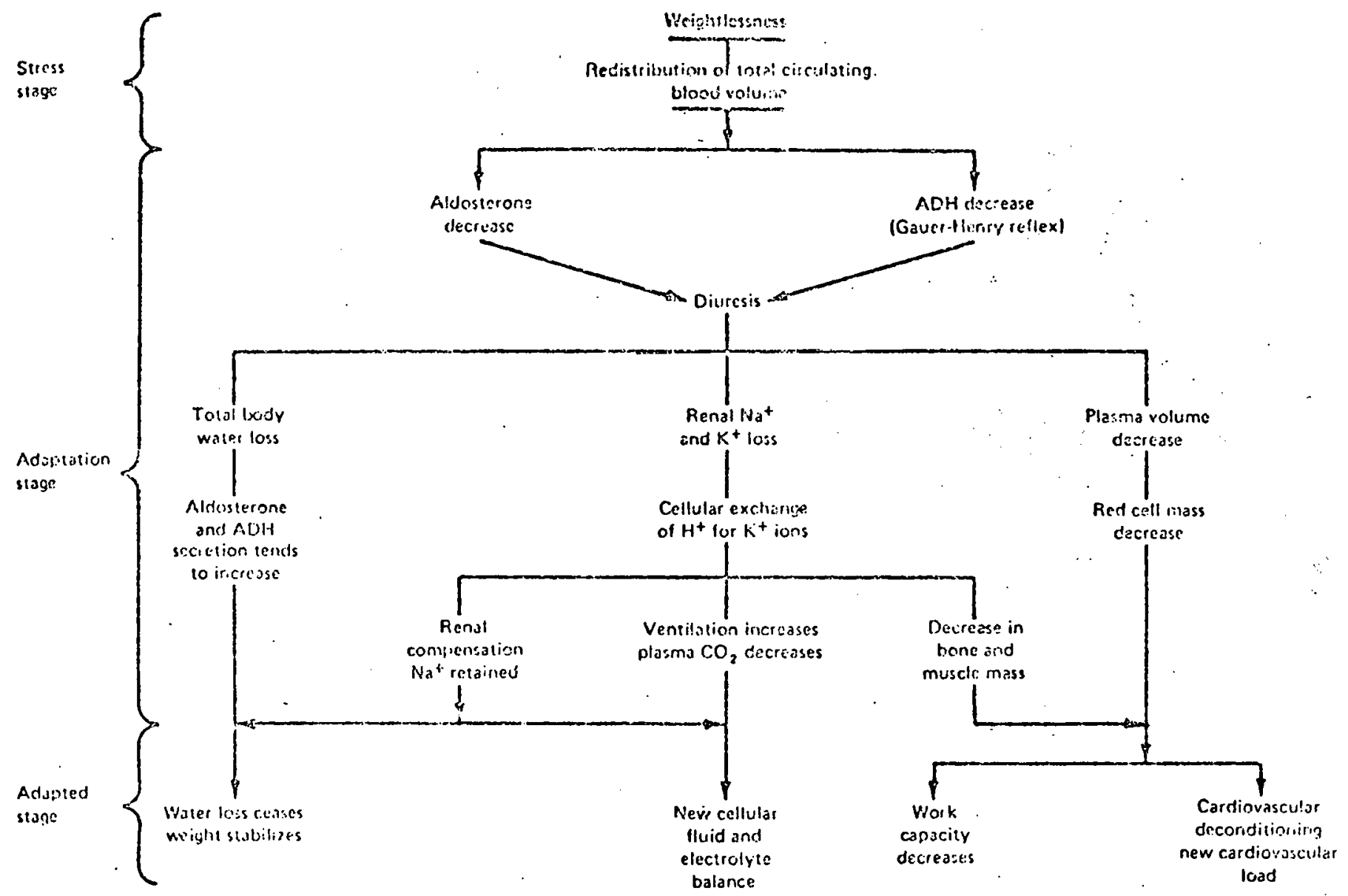

Flgure IV-2. Adspive fluid and electrolye response to weightlessness (preskylab hypothesis). 
The capacity of the humoral system can be demonstrated by enumeration and quantification of immunoglobulins and other protein fractions.

The capability of the cellular system can be estimated by determining whether 1 ymphocytes, when stimulated by a reagent, will synthesize additional nucleic acid, change shape (blastoid transformation) and subsequently engulf bacteria.

Another method of determining immune and defense status is by qualitative and quantitative estimation of microflora on astronaut's skin, mucous membranes and in their waste products pre-, in-, and postflight.

A final data source regarding immune status is the incidence of infectlous disease during zero-g exposure and postflight. In Skylab, postfiight infections included a sty, a:boil, and a presumed fungal infection.

Principal Skylab findings of the cardiovascular system which might impact missions lasting longer than six months and which need further definition are:

- Fluid redistribution inflight,

- Plasma volume decrease contributing to orthostatic intolerance,

o Red blood cell mass decrease, and

- A potential for a significant breakdown in the capability of the immune system. A depressed or changed immune system, a seltcontained environment, and decreased attention to cleanliness are conditions favorable to rapid multiplication of microbes.

\section{Nervous System}

The central nervous system has not been evaluated by quantitative tests in space, but many facets of its performance, homeostasis 1 , registering of senses ( sight, hearing, etc.), cognitive functions, problem solving, and sleep have been carried out with no hint of decrement.

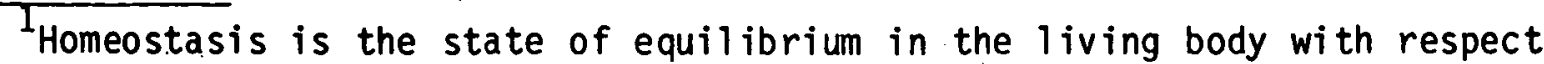
to various functions and to the chemical compositions of the fluids and tissues, e.g., temperature, heart rate, blood pressure, water content, blood sugar, etc. 
The peripheral nervous system is not known to be affected by weightlessness. However, weightless effects on other systems, e.g., altered calcium-potassium ratios, could significantly affect nerve thresholds and recovery and thus produce alterations in nerve function.

In Skylab, task performance in zero-g equaled ground baseline efforts after a few trials, and performance continued to improve with time.

Heart. rates were usually elevated inflight in the U.S. programs, particularly before stress tests. There were al so reported fluctuations in heart rate in the Soviet Union programs.

Sleep was found to be adequate in quality and duration. In the postfi ight period, REM sleep appeared earlier in the night (reduced latency) and was increased in quantity.

The Achilles tendon reflex time was generally shortened for more than four days postflight. However, for Skylab 3 there was a lengthening which returned to baseline by 29 days postflight. For Skylab 4, after the initial shortening, there was a lengthening and a return to baseline by 30 days postfi ight.

Postflight, muscle electrical activity-time shortened similarly on three crewmen and increased on one other. Two crewmen showed lengthening for less than a week and two showed shortening for a similar period before approaching base1 ine in the 30 days. A part of these changes is attributable to muscle reaction as well as to nerve conduction.

Neurophysiology

Vestibular responses in zero-g had been the subject of considerable speculation preflight because one of the sensors, the otolith, is a gravity (verticality) sensor. Ground-based tests showed it would be able to detect accelerations and decelerations occurring in zero-g, but would lose its usual one-g stimulus; the remainder of the vestibular apparatus would function in zero-g identically to the way it functions in normal gravity. Orientation with respect to gravity in zero-g would, therefore, depend on visual and tactile cues. Any misfits in the input of information were expected to result in illusions and confusion. 
In Skylab there was a variety of symptoms. Illustrations include sensations of rotation, nystagmus, dizziness, vertigo, and postural illusions.

Neurophysiological response by the vestibular and autonomic nervous systems to zero-g resulted in motion sickness symptoms. Signs included pallor, cold sweating, nausea and vomiting. Five of the nine Skylab astronauts were affected, al though not always to the vomiting stage. Inflight, complete recovery from symptoms typically occurred within three to five days. After this initial period of adaptation, crewmen were virtually free of motion sickness symptoms.

Upon return to one-g, there were severai days of unsteadiness while visual proprioceptive, motion, and gravity cues were readjusted.

Organs of Special Sense

Flight data for these sensory modalities were not quantitated on Skylab but a number of phenomena, produced by acceleration, did involve the eyes reflexly. Some visual experiences in zero-g including ocular counterroling, oculogyric illusion and oculogravic illusion represent reflex activity of the vestibular apparatus. None is abnormal, unpleasant, or incapacitating. Nystagmus, on the other hand, has the same genesis but is mildly unpleasant and temporarily interferes with vision. It is probable that all of these phenomena were experienced in Skylab but only nystagmus was reported.

Other Sensors

Homeostasis, the process through which body equilibrium is maintained, is achieved through sensors. Since the environment to which the body and its processes must adjust is al tered in weightlessness, there is concern over the adequacy of these responses. In some cases, the adjustment involves a physiological change. For these changes to be acceptable, they must be beneficial or at least not harmful, and they must be reversible upon recovery. If these criteria are not met, NASA will seek to prevent or correct the adjustments by some ameliorative technique. A first step is to determine that the sensors are functioning in a purposeful manner.

The associated matrix in section III entitled, Inventory of Human Responses to Space Flight lists data from Skylab experiments and the associated responses. Interpretations are frequently not clear and more detailed studies will be 
needed to provide suitable solutions to the problems of altered hemostasis in the weightless environment.

It appears that the nervous system has maintained its stability in the transition to zero-g, while in zero-g, in the transition to one-g, and during the body's recovery in one-g conditions. Excellent mental, behavioral and physical performance was noted both inflight and postflight. While permitting some detailed changes in the various organ systems which are adaptive in nature and, in the main, help attune the transition or an organ to a challenge, there are exceptions which the medical and scientific communities regard with caution, e.g., potassium loss, reduction in immune competence, demineralization, muscle atrophy and vestibular performance pattern changes. These may be desirable adaptations to the new environment; when they aren't, it may be that the sensors which supply information to the central nervous system (such as $\mathrm{pO}_{2}, \mathrm{pCO}_{2}$, blood volume, posture) are at fault rather than the nervous system itself.

Motion sickness is likely to occur soon after entering zero-g, and the malaise lasts for about three days. Nevertheless, duties can be accomplished during this period. Physical accommodation plus drugs may 1 imit or prevent motion sickness. Preflight screening may be necessary to el iminate sensitive individuals.

Current experience indicates vestibular responses would not be a limiting factor to extended periods in zero-g. Visual acuity, hearing, smell, taste and touch appear to be normal in zero-gravity and upon recovery, thus they are not considered to be limiting factors for STS missions.

More detailed studies will be needed to provide the background to judge the adequacy of the sensors and the systems in which they perform. In this way the enigmas of potassium and calcium loss can be solved - how sensors are involved and whether the losses are related to efforts to correct untoward electrolyte imbal ances caused by weightlessness.

The parameters of homeostatic control and the adequacy of the sensors that serve the system for adaptations to weightlessness are largely unknown. This 
is an important area for research because calcium, potassium, water and nitrogen balances are involved. The results will be important inputs to planning for STS missions.

\section{Excretory System}

The very large body of data on homostasis, hematology, food and nutrition, endocrinology, metabolism, and biochemistry in space owes its cohesiveness to the controls governing mineral and fluid balance and excretion. The principal functional unit in carrying out the operations that result in homeostasis is the kidney; it excretes excess water and, selectively, electrolytes in the proper ratio in order to maintain the necessary balance and $\mathrm{pH}$. Other materials excreted are genenally waste products. The intestine, lungs and skin also play important roles in removing products that aid in achieving homeostasis.

Functioning of the control system and the normality of creatinine excretion prove the intactness of the excretory function in zero-gravity.

There was, however, a slight increase in plasma cretinine in both Skylab and ASTP. There was nothing to suggest the risk of urolithiasis (formation of kidney stones), for which some concern has been expressed from the increased calcium excretion experienced in bed rest simulations and actual space flight; maintenance of adequate urine volumes will be obviate such risk.

Al though there were no specific challenging tests of the excretory system in space such as were performed on the respiratory and circulatory systems and musculature, nothing was found that indicates any limit to stays in space based on decrements in renal performance.

Digestive Systeill

Foods of known composition have been tested during simulations at reduced atmospheric pressures and pre- and postflight during U.S. space missions. Data from these tests have been used to establish baseline norms and postflight differences for each astronaut.

Essentially, the digestive system has functioned in a normal, predictable manner. Foods in. the Apollo Program, caused soft stools, pre-, in-, and 
postflight. Flatulence, when present, was worsened in reduced environmental pressures, in simulations and inflight. Astronauts occasionally took an antichol inergic drug (Lomotil) to control bowel activity.

There was one case of a flu-like upper respiratory condition. which was accompanied by nausea and vomiting. Also there have been cases of nausea and vomiting which were attributed to motion sickness and which lasted from one to five days.

Departures from anticipated in-and-out nitrogen and electrolyte balances were caused by muscle atrophy, bone demineralization, and excretion of more potassium than was ingested.

Future food tests will be conducted at standard atmospheric pressure; excessive flatulence should not recur, and no aspect of digestive system function should limit orbital stay times.

\section{Respiratory System}

Since the lung is a highly elastic structure with air and fluid-filled regions, it is sensitive to influence that restrict its expansion or contraction and displace or augment its fluid component, e.g., accelerations.

Very sophisticated inflight determinations of pulmonary function of Skylab showed no decrement in the ability of the respiratory system to support exercise. A loss in vital capacity attributed to fluid shift to the lung circulation offered and obstacle to achieving the deepest inspiration. This loss of vital capacity did not appear in postflight tests.

Pulmonary function suffers little or no decrement in zero-g. If there is any decrement, it is constant and not progressive. In heal thy subjects, pulmonary function does not 1 imit exercise capability. The limiting factors are usually muscular fatigue or circulatory competence, depending on the condition of the individuàl. 


\section{Reproductive System}

There have been no special tests performed to determine the effect of zero-g on the male reproductive system. Reported occurrences of congestive prostatitis and irritated urethras were caused by wearing a urinal during early space flights. Space flight has had no demonstrable affect on the male reproductive system.

A female cosmonaut (Soviet) is reported to have had normal children several years after her flight in space. While the U.S. has not used female astronauts, space simulation studies do not preclude them from taking part in future space missions.

\section{Biochemistry}

By quantitative chemical analyses, changes in the lilracellular and interst.itial body fluids can be monitored. Examples of these body fluids are plasma, lymph and cerebrospinal fluids, parotid secretion and urine.

Analyses for nutritive components (metabolites) in plasma such as amino acids, nitrogenous compounds, glucose, cholesterol and triglycerides indicate the normality or abnormality of protein, carbohydrate and fat metabolism during space flight.

As the space program matured, a battery of tests of increasing complexity carried out on plasma serum and urine, showed a number of changes. Many of these changes were similar to the effects observed in bed rest. These changes are regarded as an adaptation response to the weightless condition.

Inflight excretions of sodium, potassium, chloride, calcium, phosphate, and nitrogen were elevated. Inflight plasma sodium and chloride were reduced and plasmld calcium, phosphate and potassium were elevated. Exchangeable potassium was reduced postflight, indicating potassium depletion through the reduction in muscle tissue mass.

Metabolic processes were found to be qualitatively unaffected by weightlessness. Quantitative changes were indicated by: reduction in insulin and glucose during. flight, loss in fat stores, altered levels of metabolites of 
protein origin in the plasma suggesting a catabolic process, and losses in body water and body weight. The known changes are regarded as posing no threat as they are within normal ranges and are quickly reversible postfi ight.

\section{Endocrine System}

The physiological relationships of the endocrine system influence and regulate body functions such as excretion, metabolic and neurohumoral controls to maintain homeostatic balance as the body adapts to weightlessness. Endocrinological data are obtained from electronic monitoring of the cardiovascular, muscular, and possibly the neurological body systems, and from a detailed analyses of blood and urine specimens for levels of hormones and the substances they cause to be mobilized, excreted, metabolized, or stored. For example, cardiovascular monitoring can detect changes in heart rate and blood pressure. Electromyography detects changes in muscular physiology. Discrete levels of hormones acting on tissues are detected by blood analyses, and activity levels, which are longer lasting, are found as traces in urine. These and other data collected from fluid shifts, energy metabolism, and hematology are vital adjuncts to assessment of endocrine function and homeostatic adjustments.

In Skylab, levels of the following hormones were estimated in plasma (serum) or urine, or both; adrenocorticotrophic hormone (ACTH), cortisol, angiotensin I, aldosterone, insul in, human growth hormone, thyroxine, thyroid stimulating homone, testosterone (andosterone), parathormone, calcitonin, antidiurentic hormone, epinephrine, norepinephrine, total 17-hydroxcorticosteroids and total 17-ketosteroids. Of these, cortisol, epinephrine and norepinephrine are usually associated with physical and emotional stress.

Significant changes were observed, which varied in magnitude and direction. They all disappeared shortly after return to Earth. The changes are for the most part indicative of a successfur adaptation by the body to the combined stresses of weightlessness and flight. It is evident that a new, stable level of homeostasis is achieved in space and the safe exposure times of crewmen to the weightless environment is not 1 imited. 
The neurohumorally controlled changes predicted to occur in the process of adaptation to weightlessness are diagramed in figure IV-2. The predictions were borne out in well over half the areas which were highlighted. The remainder are areas in which predictions were borne out equivocally, or negatively demonstrate that there are unknown mechanisms or that the mechanisms have as yet been imperfectly described.

Energy Metabolism (Metabol ic Activity, Work Capacity, Exercise Tolerance)

In normogravity, weight and friction induced by gravity usually suffices to maintain a person's stance at a chosen place.

Coversely, maintaining one's stance at a chosen place in zero-g requires means for restraining or stabilizing oneself so that one can exert forces without being displaced, and preferably without having to use muscular energy.

In the space program, early efforts were centered on devices involving thrusters to aid mobility and restraint. In the Gemini program, mobility did not suffer but extravehicular (EVA) activities were compromised by lack of restraints to ther extent that seemingly simple tasks caused overwork and produced more metabolic heat than the space suits could handle. These findings caused a shift of emphasis from mobility devices to stabilizing and restraint devices.

In skylab, it was tound that the isotonic task of riding a cycle ergometer uffered no more of a challenge than in one-g, and, in time, astronauts became more efficient in zero-g. This test was not carried to a maximum effort, however, but was at a high level, 230-286 watts, roughly 1/3 horsepower.

Maximum-effort arm and leg flexion and extension showed small decrements when tested postflight against a dynamometer. With increasing allied exercise on a zero-g treadmill and other exercise devices, the decrements became less than $0.1 \%$ per day in leg extension maximum effort.

Somewhat similar measurements were made postflight in Skylab and ASTP with an isometric task, while electromyography (EMG) was employed. In this case, it was noted that EMG changed during holding of less than maximum effort forces, fatigability was enhanced, and efficiency was degraded. 
Postflight, the Skylab astronauts showed severe decrements in work capacity on a stationary cycle ergometer. It became apparent that the cardiac output was too low to support the levels of exerise that were used preflight and inflight, hence the problem was in readapting the one-g conditions.

Recovery to baseline capability required, usually, less than a month, but there were decrements in strenuous whole body exercise capability, such as running, for approximately two months. Astronaut reported experiences are parallel. They feel that the appropriate period for rehabilitation following space flight is three months.

The physiological responses to exercise inflight showed differences that can not be generalized for all crewmen. These included decreased recovery heart rate, decreased systolic blood pressure, decreased diastolic blood pressure, increased resting respiratory minute volume, increased pulmonary ventilation, decreased or increased oxygen consumption and carbon dioxide production, decreased pulmonary efficiency llung ventilation necessary to provide a certain oxygen consumption), and decreased mechanical efficiency (oxygen comsumption necessary to provide a certain level of energy output). These changes did not degrade the capability to perform submaximal exercise but did show that the quantitative relationships among cardiovascular, respiratory and musculoskeletal parameters that were obtained during preflight testing were not maintained in flight.

Flight menus were designed to meet comparable individual energy requirements under normal gravity conditions, specified nutrient levels, and crew-selected preferred foods. Energy requirements calculated for each Skylab crewman averaged 45.68 kilocalories (Kcal) per kilogram $(\mathrm{kg})$ of body weight per day with a standard deviation of $4.50 \mathrm{Kcal} / \mathrm{kg} /$ day. Based on inflight changes in total body weight, muscle mass, and body volume, they lost weight.

The estimated energy required to maintain a crewman during the ASTP mission was approximately $39 \mathrm{Kcal}$ per $\mathrm{kg}$ of body weight per day. This estimate was based upon preflight measurement of lean body mass and adjustments for inflight activity levels. Al though this lesser amount was thought to be adequate because of the brevity of the ASTP mission and the failure to achieve metabolic stabilization, these crewmen lost weight al so. 
An awareness of the true energy demands should be kept in mind for an understanding of the degree of metabolic energy needed for productive work inflight and without loss of body weight.

The cycle ergometer is regarded as an excellent testing tool but inadequate for maximal stress to the individual and not suited to an important musculoskeletal parameter, maintenance of bone and muscle intergrity, and particularly of antigravity muscles and weight-bearing bones.

It was found that exercise tolerance was maintained quite well in zero- $\dot{g}$ by a program that supplemented ergometry with exercise devices which emplnyed the anti-gravity muscles and weight-bearing long bones. The most pertinent. devire resembles a functional treadmill.

It is apparent that work can be done efficiently in a weightless environment if tasks are properly designed. Man's capability of living and working for long periods of time in zero-g do not appear to be limited by bioenergitic considerations.

Physiological Limits

Definitive limits have not as yet been established for continuous or cumulative exposures to the weightlessness of space flight. Several physinlogical effects mentioned in the previous discussion could ultimately impose limits on zero-g exposure. Bone demineralization is the most apparent effect of weightlessness that could limit flight durations in the SPS program. Degeneration of gravity receptors is another potential 1 imiting factor for space-flight duration; however, the nature and time course for the development of this effect remain speculative. Both of these effects are only realized with rcappcarance of gravitational or other external forces. Other physiological effects of weightlessness, such as cardiovascular deconditioning, loss of plasma volume, and immunosuppression, may not be current limiting factors to space-flight duration but will require monitoring and deployment of appropriate countermeasures.

Motion sickness appears to be a time-limited annoyance that interferes with performance. The fluid shift and spinal lengthening that interferes with 
fitting and wearing of emergency equipment and with physical comfort at work station equipment can be remedied by forethought and application of better bioengineering designs.

Exposure limits must be derived through further experimentation and/or progressively increased exposures to zero-g. When established, these limits will likely be a function of the availability of. effective countermeasures. Moreover, with sufficient progress in these countermeasures, weightlessness, as such, may not be the most critical factor for limiting long-duration space fl ight.

Space experience in the U.S. to date has shown that man can live and work in space for periods of as long as 84 days. It has al so shown that the most deleterious effects of zero-g exposure may not be realized until return to one-g and subsequent readaptation. From physiological evidence amassed through extensive experimentation in cardiovascular, hematological, endocrinological, vestibular, and musculoskeletal systems, it can be stated that the tentatively allowable exposure period to zero-g can be safely extended to 6 months. This may not apply to reexposure to zero-g after a recovery period in one-g; a cumulative problem of more seriousness than an initial exposure to weightlessness may appear.

Physiological measurements and performance parameters should be carefully monitored during these extended missions to detect debilitating changes that might occur. This approach of systematically increasing exposure times can be continued until physiological limits are approached or until operational goals are realized.

\section{B. EFFECTS OF ACCELERATION/DECELERATION}

Physical forces act on the body to cause acceleration and displacement of the whole or some part of the body. The extent and the circumstances of the response of the body to force may result in a range of physiological responses from a level at which no effect can be perceived or measured to a level resulting in massive tissue destruction. This section represents an attempt to differentiate and define the types of forces that may act on the body, to 
identify the physiologic effects, to present limits for these forces, to present the rationale for these limits, and to identify areas in which additional research is required. For the purposes of this section, the forces will be divided into those resulting in sustained linear acceleration and in angular acceleration.

NASA has very 1 imited information on the effects of acceleration/deceleration in space flight and will be unable to provide substantial information regarding these environments until further research is accomplished.

The results compiled by NASA of extensive studies involving "ground-based" testing on subjects who have resided in a one-g environment is presented here.

The reader is advised to use care in the application of the information presented here. Although very limited quantitative analyses and test results exist, it is known that the nature of the response of the body to 1 inear and angular accelerations is altered when in the weightless enviromient and upon return to one-g after a space flight. The duration of exposure to weightlessness is known to influence the extent to which the response of the body to acceleration is altered and al so the length of time to readjust to normal preflight response characteristics.

\section{Sustained Linear Acceleration}

Definitióli dild Descriptión

Sustained linear acceleration can be defined as the response of an object or a body to a net directional force applied over a duration of 0.2 seconds or more.

Linear acceleration occurs whenever there is a change in velocity of the spacecraft (e.g., during spacecraft launches and entries). The nature of the response of the body to linear acceleration depends on a number of characteristics of the force and resultant acceleration.

The magnitude of the force acting on the body and the mass of the body determine the magnitude of the acceleration. The duration of the acceleration is a significant factor in the response of the body, particularly at the shorter 
duration exposures approaching impact (duration < 0.2 second). Also significant are the direction of the force vector, the resultant direction of acceleration with respect to the orientation of the body, and the specific body position. The restraint and support systems for the human body in an accelerating vehicle determine the manner in which forces are transmitted from the vehicle to the body and thereby strongly influence the physiological response to the acceleration.

The symbol $g_{0}\left(g_{0} \times g\right)$ represents a unit of acceleration equal to $980.665 \mathrm{~cm} / \mathrm{s}^{2}$ and equal to the acceleration resulting from the unopposed force of gravity at sea level. The symbol $G$ is used to denote a nondimensional, relative measure of either acceleration expressed in multiples of $\mathrm{g}_{0}$ or a force field expressed in multiples of the force of gravity. The unit $G$ is used to represent acceleration in describing the physiological stresses in response to acceleration and is sometimes referred to as a unit of physiological acceleration.

Acceleration is a vector quantity, and, in the literature on the effect of acceleration on mammalian subjects, the direction or vector of $G$, or the $G$ load; is denoted by the North Atlantic Treaty Organization Advisory Group for Aeronautical Research and Development (AGARD) convention shown in figure IV-3.

The symbols $G_{x}, G_{y}$, and $G_{z}$ are used as units to express inertial resultants to whole-body linear acceleration in the three orthogonal axes in multiples of the magnitude of the acceleration of gravity $g$. In this usage, $G$ is the inertial force of the body resisting acceleration and the $G$ vector is in the direction opposite that of the vehicle acceleration. The symbols $R_{x}, R_{y}$, and $R_{z}$ denote angular acceleration about the three orthogonal axes as discussed in the section entitled "Angular Acceleration." 


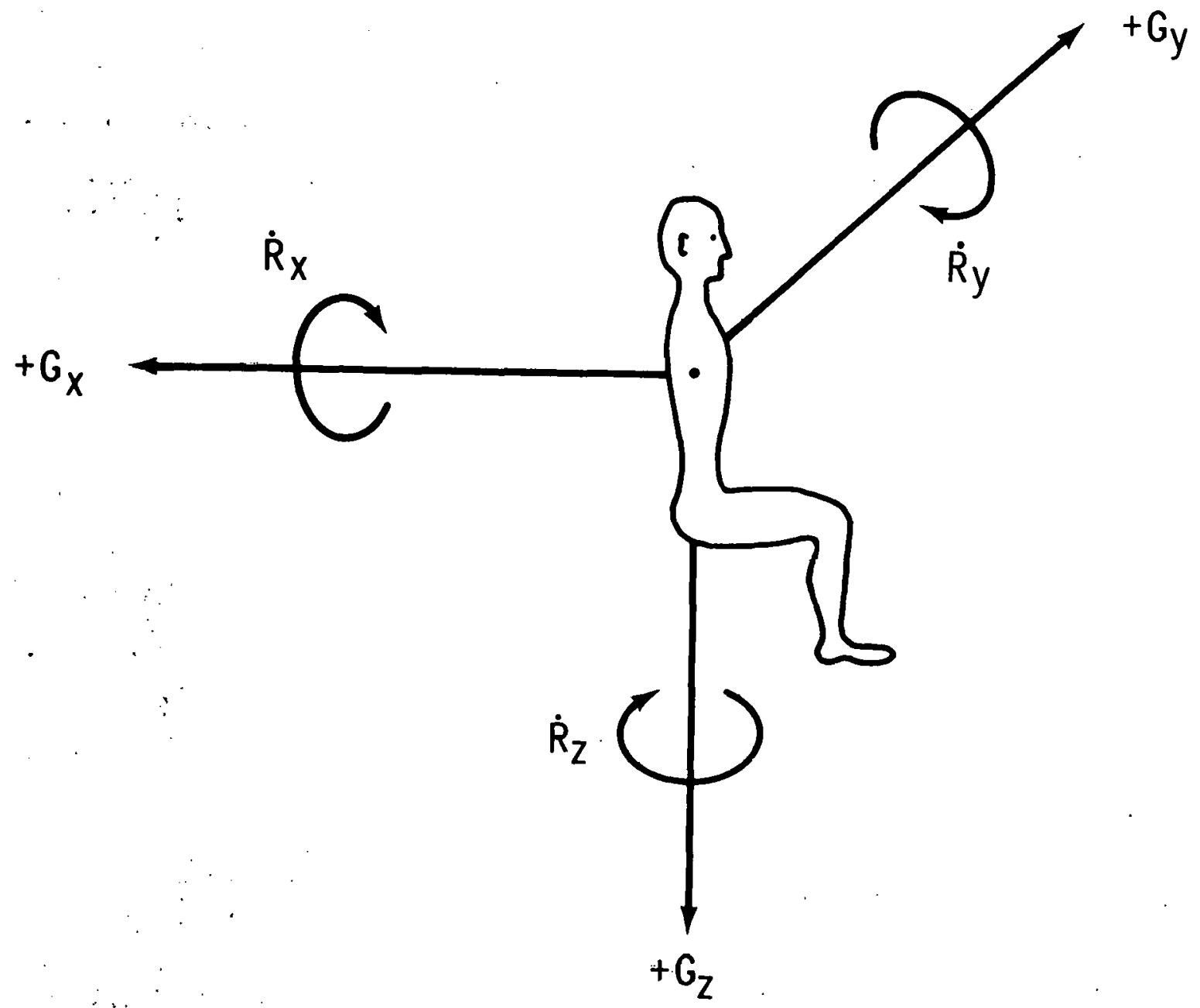

Figure IV-3. ${ }^{\circ}$ AGARD physiological acceleration system.

\section{Physiological Effects}

The physiological response to sustained linear acceleration is a rosponse to the forces and pressures acting on the body to cause the acceleration. On the surface of the Earth, the force of gravity acts on every element. nf hody mass. This force is directional toward the center of the Earth. When a body is stationary on the surface of the Earth, the force of gravity is countered by an equal force vector in the opposite direction. This force is effective at the points of contact of the body with the Earth but must be transmitted to each element of body mass if the acceleration of the element is to be prevented. The structure of the body has evolved under one-g conditions and is adapted to the transfer of forces supporting the body (resisting acceleration to the center of the Earth) for those body positions that are normally assumed nn Earth. 
When a space vehicle is accelerated at a given rate, the forces generating the acceleration must be transmitted from the rocket engines to all mass elements of the vehicle and to all mass elements of the passengers. The physiological effect of acceleration occurs when the structure of the body is not capable of transmitting applied forces to each element of the body with the result that relative movement of body elements occurs and relative pressures within the body are altered. These effects will be considered in the following paragraphs for different axes of acceleration as defined in figure IV-3 and for the physiological systems most limiting in each axis.

The cardiovascular effects of acceleration are generally the most significant. The force causing the acceleration of the body is transmitted to the blood. This transmittal of force is accomplished by the following sequence of events. Blood is displaced in the direction opposite the accelerative force. This displacement is resisted by the elastic tissues of the body so that a pressure gradient is created in the vector opposite that of the force causing the acceleration. Engorgement and pooling of blood occurs in the areas of the body that experience higher than normal blood pressure. Diminished blood fiow rates and poor oxygenation of tissues result in those areas of the body that experience lower than normal blood pressure. The greatest changes in cardiovascular pressures occur when the acceleration vector is parallel to the course of the major blood vessels of the body $\left(G_{z}\right)$. The effects are most severe when these pressures displace blood from the head $\left(+G_{z}\right)$. Progressively reduced blood pressure in the head will result in loss of visual acuity, grayout, blackout, and finally unconsciousness as the oxygenation of the eyes and the brain is progressively reduced.

The respiratory effects of acceleration result from a change in relationship of pressure differentials, which, in a one-g environment, facilitate respiration and gas exchange. In a supine subject in a one-g environment (where the force of gravity is effective in the ${ }^{+} G_{x}$ orientation), there is normally a gradient in intrapleural pressure and in both arterial and venous pressures from dorsal to ventral chest walls (figure IV-4). These gradients do not interfere with inflation and deflation of the lungs or with perfusion. However, under severe G loading, the pressure differentials at the intrapleural 
interface resulting from the acceleration become more. significant. Modification of intrapleural pressure by exertion. of respiratory musculature in the chest wall becomes insufficient to inflate the alveoli near the dorsal chest wall or to empty the alveoli.near the ventral chest wall. In addition, the pressure gradients in the blood vessels reduce or el iminate perfusion of the alveoli near the ventral. chest wall. Respiration is affected by acceleration in all axes but is affected most significantly by $+C_{z}$ acceleration. Respiratory effects are more likely to be the limiting factor in $+G_{x}$ acceleration, however, because there is greater tolerance to cardiovascular effects in that vector.

There are direct effects of forces due to acceleration on all the body organs and systems as well as effects secondary to the hypoxia that may result from the cardiovascular and respiratory al terations and to hormonal response to the general body stress. Figure IV -5 depicts some of the interrelationships that may occur at different functional levels.

Table IV-1 contains a listing of subjective effects of sustained acceleration in each of the possible vectors. These subjective effects derive from the physiologic effects that have been described previously and bear on the tolerance limits that will be discussed in the following paragraphs.

To date, NASA 1 imits launch and landing accelerations to levels of $3-y$ or 1 ess. 


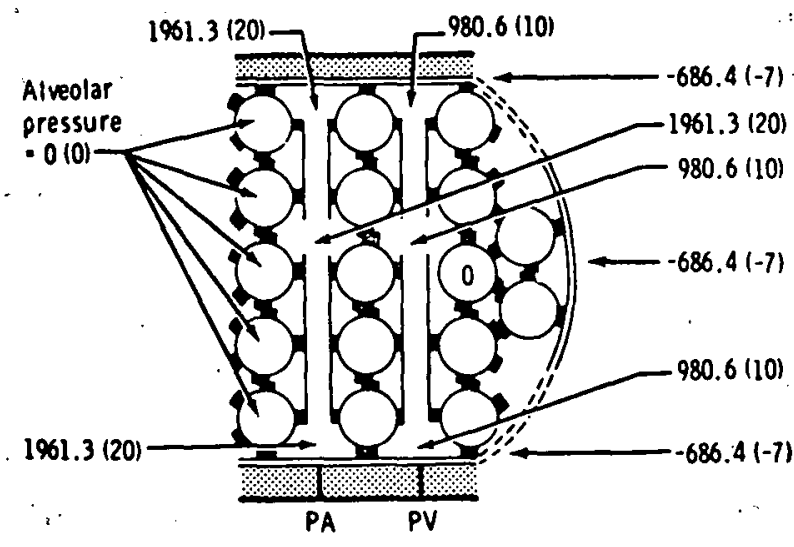

(a) Null gravity.

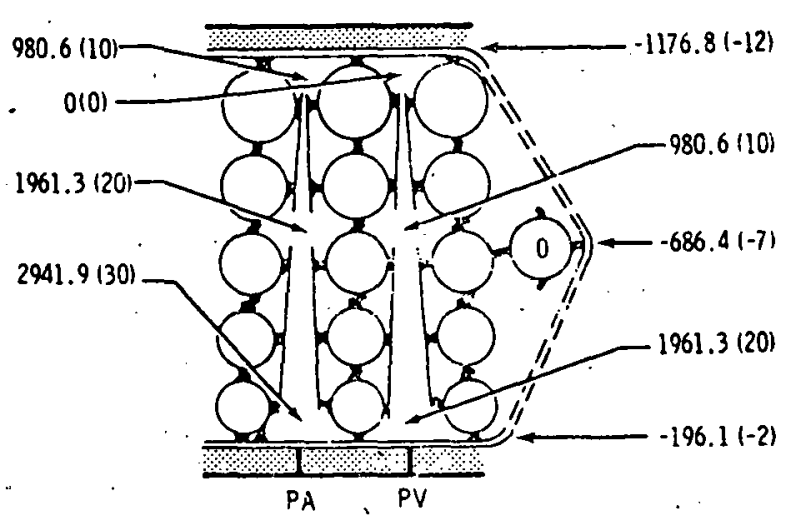

(b) Normal gravity.

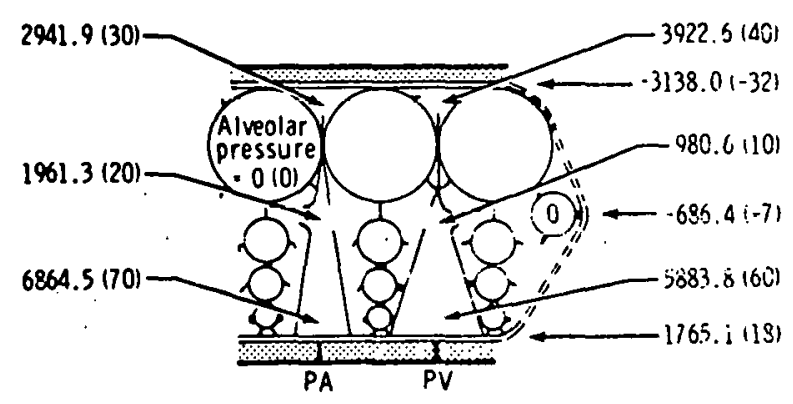

(c) Acceleration of 5G.

Figure IV-4. Influence of $+G_{x}$ accelerative stress on intraperitoneal pressure. The dorsoventral dimension of the lung is 20 centimeters; the ventral chest wall is at the top and the dorsal chest wall at the bottom. The single zeros denote atmospheric pressure in the central portion of the thorax in the plane of the heart. The values represent positive and negative intrapleural pressures (with directional arrows) and positive pulmonary pressures (i.e., $P A=$ arterial pressure and PV - venous pressure) expressed in newtons per square meter (centimeters of water). 


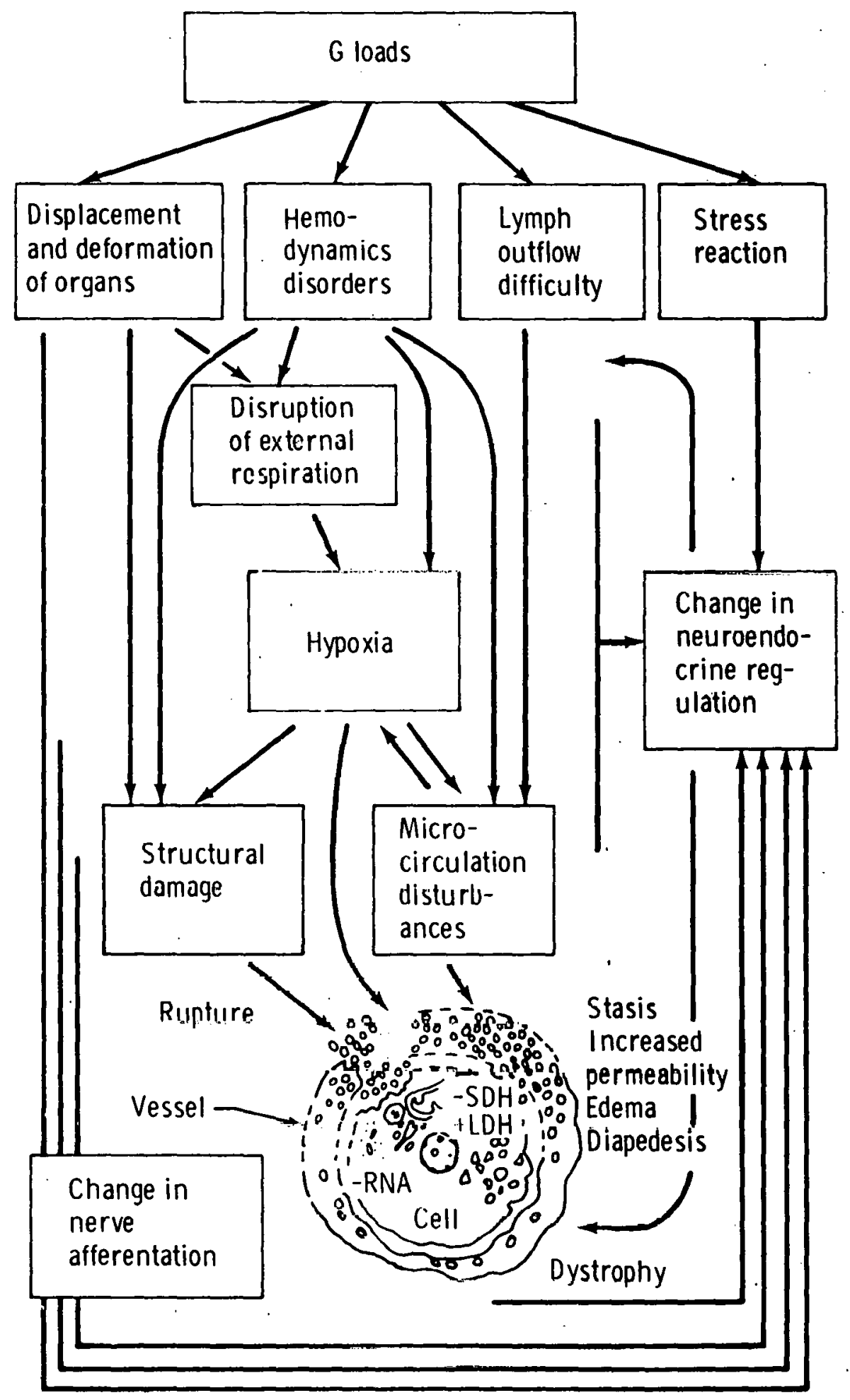

Figure IV-5. Basic mechanisms of accelerative action on an organism. Cell changes consist of increased activity of lactate dehydrogenase, (+LDH), reduced activity of succinate dehydrogenase $(-S D H)$, and reduced quantity of ribonucleic acid (-RNA) in cytoplasm. 
TABLE IV-1.- SUBJECTIVE EFFECTS OF ACCELERATION

\begin{tabular}{|c|c|}
\hline Magnitude, $G$ & Effects \\
\hline & Positive acceleration $\left(+G_{z}\right)$ \\
\hline 1 & Equivalent to the erect or seated terrestrial posture. \\
\hline 2 & $\begin{array}{l}\text { Increase in weight, increased pressure on buttocks, } \\
\text { drooping of face and soft body tissues. }\end{array}$ \\
\hline 2.5 & Difficult to raise oneself. \\
\hline 3 to 4 & $\begin{array}{l}\text { Impossible to raise oneself, difficult to raise arms and } \\
\text { legs, movement at right angles impossible; progressive } \\
\text { dimning of vision after } 3 \text { to } 4 \text { sec, progressing to tun- } \\
\text { neling of vision. }\end{array}$ \\
\hline 4.5 to 6 & $\begin{array}{l}\text { Diminution of vision, progressive to blackout after ap- } \\
\text { proximately } 5 \text { sec; hearing and then consciousness lost } \\
\text { if exposure continued; mild to severe convulsions in } \\
\text { about } 50 \text { percent of subjects during or following uncon- } \\
\text { sciousness, frequently with bizarre dreams; occasionally } \\
\text { paresthesias, confused states and, rarely, gustatory sen- } \\
\text { sations; no incontinence; pain not comon, but tension } \\
\text { and congestion of lower limbs with cramps and tingling; } \\
\text { inspiration difficult; loss of orientation for time and } \\
\text { space as long as } 15 \mathrm{sec} \text { after acceleration. }\end{array}$ \\
\hline
\end{tabular}

Negative acceleration $\left(-G_{2}\right)$

1 Unpleasant but tolerable facial suffusion and congestion.

2 to 3 Severe facial congestion, throbbing headache; progressive blurring, graying, or occasionally reddening of vision after $5 \mathrm{sec}$; congestion disappears slowly, may leave petechial hemorrhages, edematous eyclids.

5 Limit of tolerance, 5 sec; idrely rcached by mnst. subjects. 
TABLE IV-1.- Continued

Magnitude, $\mathbf{G}$

Effects

Forward acceleration $\left(+G_{X}\right)$

2 to 3 Increased weight and abdominal pressure; progressive slight difficulty in focusing and slight spatial disorientation, each subsiding with experience; $2 G_{x}$ tolerable at least to $24 \mathrm{hr}, 4 \mathrm{G}_{\mathrm{x}}$ for at least $60 \mathrm{~min}$.

3 to 6 Progressive tightness in chest $\left(6 G_{x}, 5 \mathrm{~min}\right)$, chest pain, loss of peripheral vision; difficulty in breathing and opeaking; ulurring of vision; effort required to maintain focus.

6 to 9 Increased chest pain and pressure; breathing difficult, with shallow respiration from position of nearly full

- inspiration; further reduction in peripheral vision, increased blurring, occasional tunneling, great concentration to maintain focus; uccasional lacrimation; body, legs, and arms cannot be lifted at $8 G_{X}$; head cannot be lifted at $9 G_{X}$.

9 to 12 Breathing difficulty severe; increased chest pain; marked fatigue; loss of peripheral vision, diminution of central acuity; lacrimation.

15

Extrefue difficulty in breathing and speaking; eevcre viselike chest pain; loss of tactile sensation; recurrant cunplete loss of vision.

Barkward aoccleration $\left(-G_{\mathbf{x}}\right)$

Similar to effects nf $+G_{x}$ aeceleretiun wlr! mojificstior: produced by reversal of force vector. Chest pressure reversed, hence breathing eacicr; pain and discomfort from outward pressure toward restraint harncas manifuet at approximately $-8 G_{x}$; with forward head tilt, cerebral hemodynamic effects manifest akin to $-G_{z}$; distortion of $v$ ision at $-6 G_{x}$ to $-8 G_{x}$; feeling of insecurity from pressure against resträint. 
TABLE IV-1.- Concluded

\begin{tabular}{|c|c|}
\hline Magnitude, & Effects \\
\hline & Lateral acceleration $\left( \pm G_{y}\right)^{a}$ \\
\hline 3 & $\begin{array}{l}\text { Discomfort after } 10 \text { sec; pressure on restraint system, } \\
\text { feeling of supporting entire weight on clavicle; inertial } \\
\text { movement of hips and legs, yawing and rotation of head } \\
\text { toward shoulder; petechiae and bruising; engorgement of } \\
\text { dependent elbow with pain. }\end{array}$ \\
\hline 5 & $\begin{array}{l}\text { External hemorrhage; severe postrun headache (14.5-sec } \\
\text { duration). }\end{array}$ \\
\hline
\end{tabular}

alitle information available.

Physiological Limits

The accelerations that occur or are predicted during space flight can be quantified. However, the concentration of force and the relative displacement within the body which are the causative agents of the physiological effects are very difficult to quantify. The physiological effects are very difficult to quantify. The physiological limits are therefore most easily stated in terms of acceleration. Different empirically defined limits can be shown to apply under a variety of conditions of body support and restraint (figure IV-6). The effects of these supports are to distribute the force over the body and to restrict deformation and changes in volume of body segments. The most effective restraint is immersion in water. When the body is immersed in water, it becomes part of the liquid system in which it is immersed and there is good transfer of force without deformation. The air cavities in the body do allow some deformation that becomes limiting at higher $G$ levels. Tolerance varies as a function of acceleration vector as shown in figure IV-7. During practical space operations, it is unlikely that an acceleration will be restricted to one vector. Since reduced tissue oxygenation and reduced respiratory ventilation are both likely to be effects of high levels of acceleration, it is not surprising that pressure breathing and enriched-oxygen 
breathing mixtures have been shown to increase tolerance to acceleration. Figure IV-8 shows the upper limit of tolerance of a group of highly motivated test pilots suitably restrained without water immersion. It can be compared to the average tolerance values depicted in figure IV-6. The tolerance 1 imits, therefore, must be stated in terms of the acceleration. The heavy solid line in figure IV 7 is a plot of required acceleration to achieve Earth orbit against the required duration of that acceleration. Plotted on the same graph are some nominal limits for acceleration. This plot illustrates the physiological trade-off that must be made between short-duration, high-G loads and much longer duration, lower G loads.

Because overall human tolerance to sustained linear acceleration in the transverse $\left(+G_{x}\right)$ axis is effectively twice that in the vertical $\left(+G_{z}\right)$ axis, all manned space vehicle launches and entries before the Space Shuttle have oriented thrust near the $+G_{x}$ axis. Maximal peak $+G_{x}$ forces for the Apollo spacecraft reached approximately six-g on entry with lesser values for launch and orbital maneuvers. Mercury and Gemini spacecraft operated at slightly higher values (figure IV-9). No acute operational problems, significant physiological deficits, or clinical sequelae related to the cardiovasuclar and musculoskeletal systems are known to have resulted.

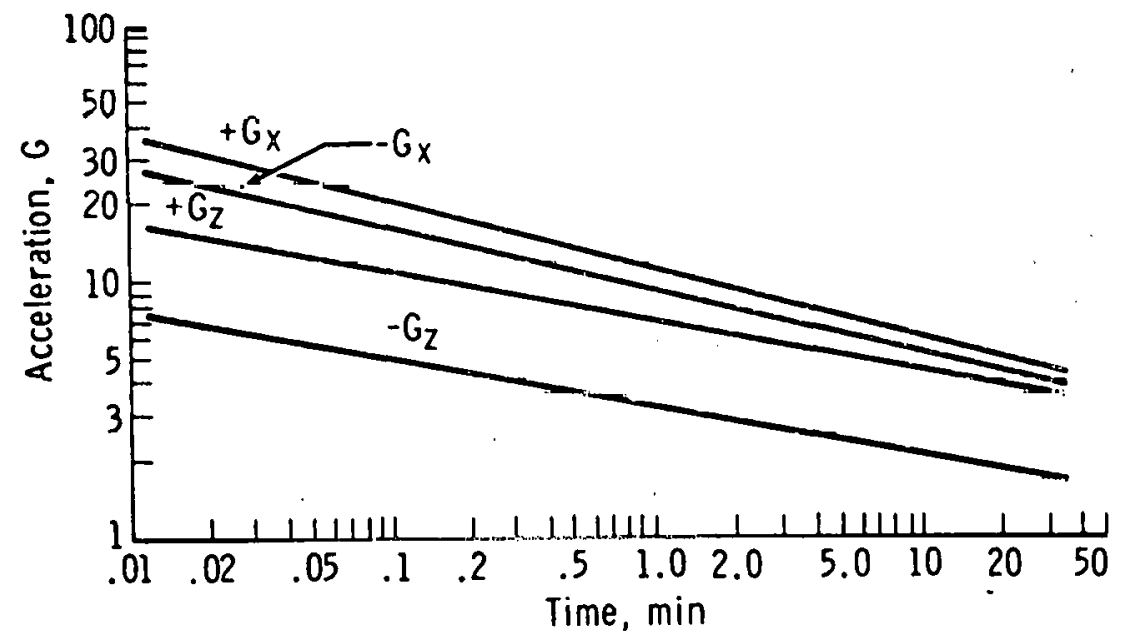

Figure IV-6. Comparison of average $G$ tolerance in four vectors of sustained linear acceleration. 


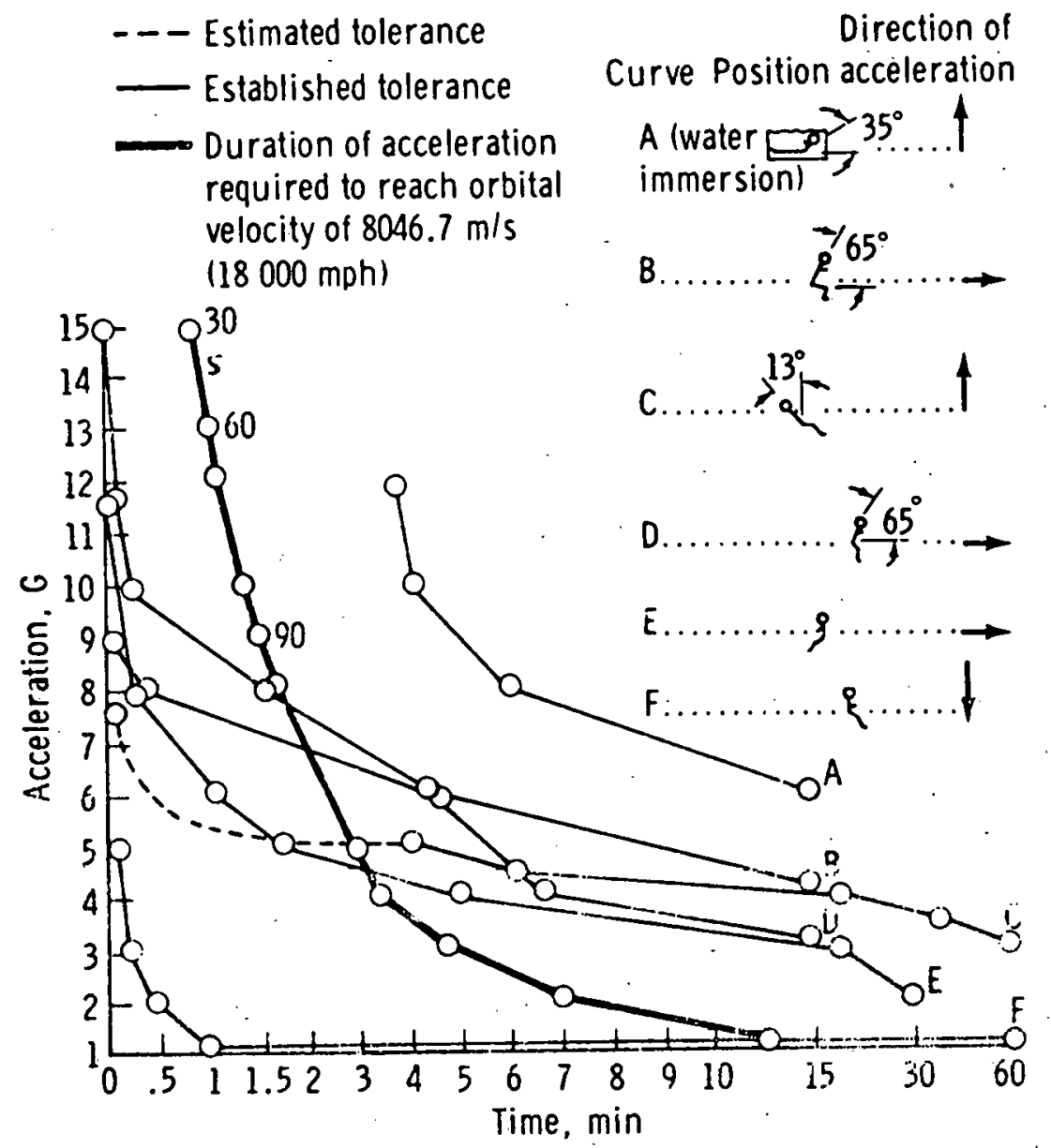

Figure IV-7. Effect of body position and posture on tolerance to acceleration. The time scale (abscissa) is linear but nonproportional.

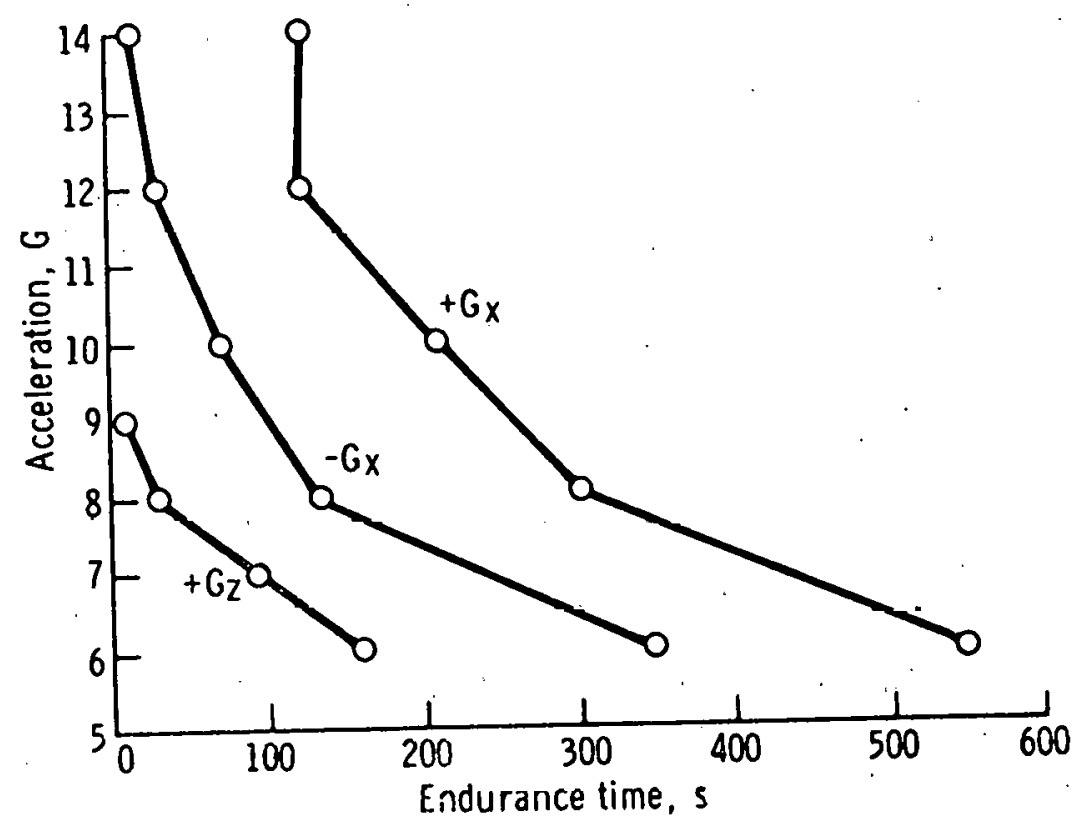

Figure IV-8. Voluntary endurance of acceleration by highly motivated test pilots. 
The Space Shuttle vehicle will impose quite a different acceleration environment on the crew. The G loads will be lower but will have a longer duration (figure IV-10). Visibility requirements during landing necessitate an orientation of the crew couches that results in an acceleration during entry that is primarily in the ${ } G_{z}$ vector. A cardiovascular counterpressure garment covering the legs and lower torso is being made available for use during Space Shuttle Orbiter entries to reduce the effects of this acceleration.

Acceptable limits of acceleration for normal, heal thy adults are in the range of $8 G$ to $10 G$ in the positive $x$-axis and $3 G$ to $5 G$ in the positive $z$-axis; this is dependent upon individual tolerance, required functions and performance, and use of restraining devices, and assumed relatively slow rise gradients and finite durations. The time magnitude interval is very important to overall tolerance.

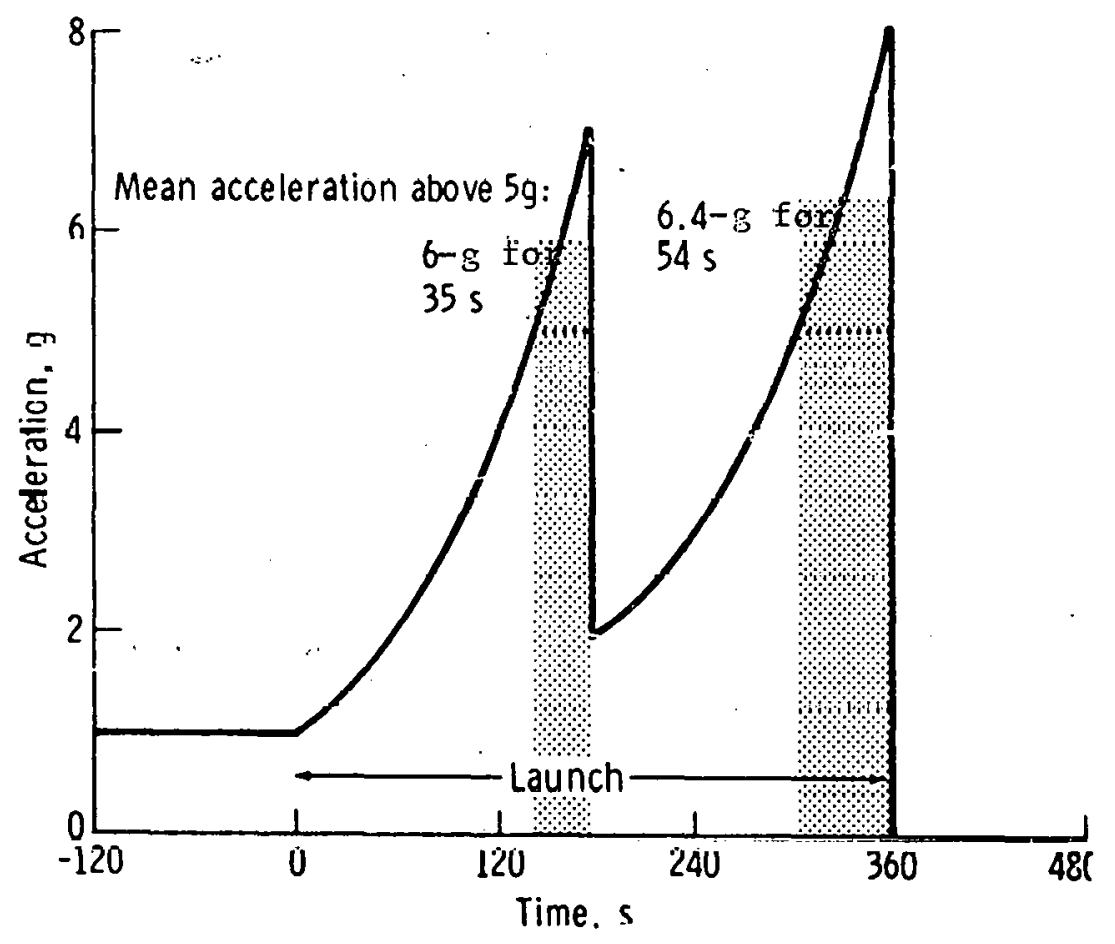

Figure IV-9. Acceleration profile of launch phase of the manned Mercury-Atlas 6 orbital flight. Strippled areas show periods of acceleration greater than $5-\mathrm{g}$. 


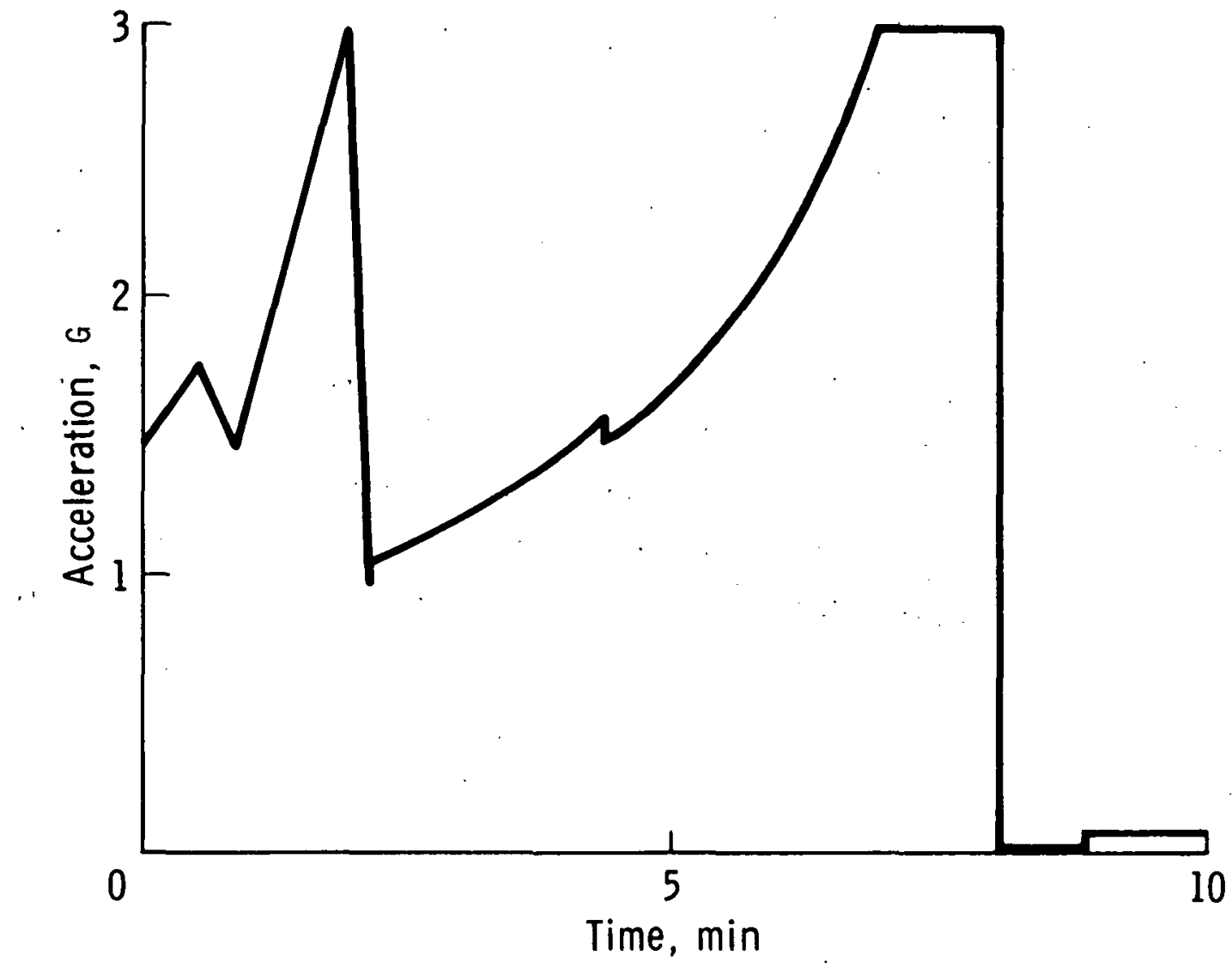

(a) Launch.

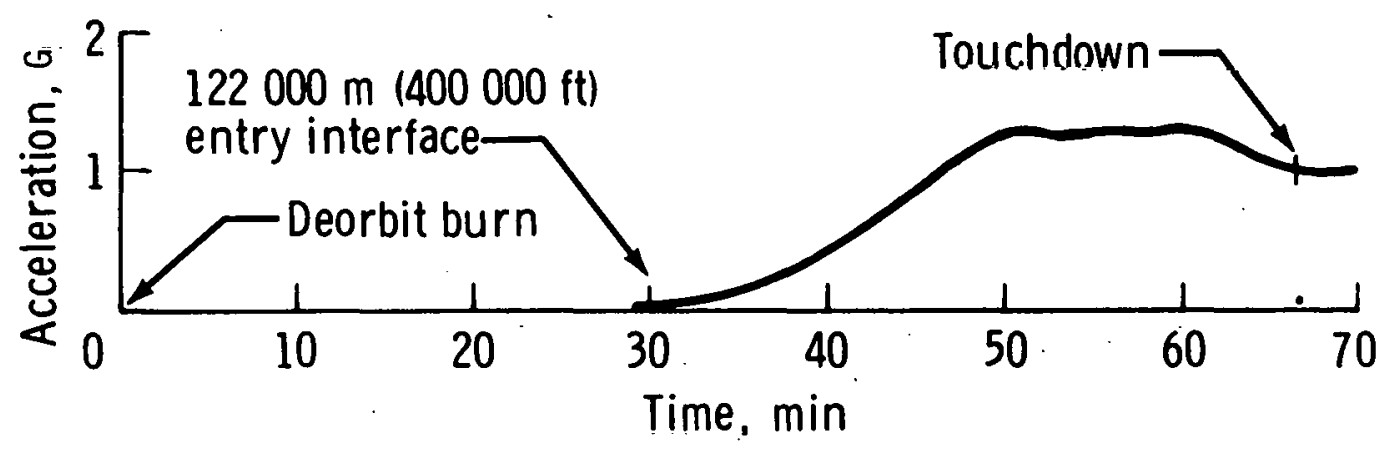

(b) Entry and landing.

Figure IV-10. Acceleration profiles of the Space Shuttle vehicle as a function of time. 
Interacting Environmental Parameters

Since the physiological effects of an acceleration force field are many, the potential for modification of these effects by a number of environmental factors should be considered. As stated previously, the primary limiting effects of high gravitational forces are a loss of oxygenation due to effects on the cardiovascular and the respiratory systems. 0xygen pressure is, therefore, a very important interacting variable. Temperature can be expected to interact when it results in vasodilation and decreased cardiac return. Any other environmental factor that might affect the cardiovasuclar or respiratory system would be expected to influence acceleration tolerance.

Errecl of Individual variation

Figures IV-6 (average tolerance curves) and IV-8 (maximum tolerancc for test pilots) provide some indication of the effect of individual variation on tolerance to a force field. However, in space Shuttle missions and in other future space missions, a much more diverse population may be exposed to force fields other than that due to gravity at sea level.

Research Needed to Further Define Spacecraft Limits

Research is needed to provide the following:

o Definition of the effects of various durations in a null-gravity environment on subsequent tolerance to force fields in all axes.

- Definition of the range of acceleration forces resulting in physiological effect and of tolerance in the nopulation that may fly in space.

o Optimization of countermeasures that may be used under high-force-field conditions.

Angular Accerleration

Definition and Description

Angular acceleration can be defined as the response of an object or a body to a combination of force vectors that results in a change in direction of motion of the object. Radial acceleration is angular acceleration that occurs during circular motion with the axis of rotation either within the body or outside the body. Rotary acceleration is radial acceleration for which the axis of rotation is within the body subjected to the acceleration. 
The convention for describing orientations of angular acceleration is given in figure IV-3. The symbol $+R y$ refers to pitch, tumbling, or rotation around the $y$-axis; $\pm R x$ refers to rolling, spin, or rotation around the $x$-axis; and $\pm R z$ refers to yaw, yaw spin, or rotation around the z-axis.

\section{Physiological Effects}

The physiological effects of the force resulting in angular acceleration are in part similar to the effects of the forces resulting in linear acceleration. The forces acting on the body are a function of the radius of rotation and the velocity. As the axis of rotation increases in length relative to the size of the body, the physiological effects of the angular acceleration approach the effects of linear acceleration and the same types of cardiovascular and respiratory effects occur. As the radius of rotation being considered approaches the dimensions of a man, forces act in different directions in different parts of the body, and, since the force increases as the square of the distance from the center of rotation, the cardiovascular and respiratory responses are com$p l i c a t e d$. The $+R x$ rotation around an axis passing through the heart produces pooling blood in the feet similar to $+G_{z}$ acceleration and at the same time produces an increased hydrostatic pressure in the head similar to $-G_{z}$ linear acceleration. Movement of the center of rotation toward the feet increases the $-G_{z}$ effects. Conversely, movement of the center of rotation toward the head increases the $+G_{z}$ effects. The same types of considerations apply to $+R y$ and $\underline{R}_{\mathbf{z}}$ acceleration.

The other major effect of angular acceleration is in the vestibular system. The discussion of these vestibular effects will be very brief in this section, and the reader is referred to reference 58 for more detailed discussion. Each vestibular apparatus is made up of three semicircular canals and two otolith organs. These sensory organs provide information that aid in orientation and in eye, head, and body coordination. The otolith organs, the urticle and the saccule, act as detectors for 1 inear acceleration, whereas the semicircular canals operate as detectors of angular acceleration. The vestibular system evolved under earth gravity conditions, in which acceleration is limited by the normal self-induced motions of the individual. When the vestibular system is exposed to much higher accelerations and combinations of forces, the effect can be motion sickness and/or sensory illusions resulting in disorientation. 
These effects are likely to be 1 imiting factors, at least in terms of performance, during rotational acceleration and in short-radius angular acceleration. If angular acceleration were to be used to integrate an artificial gravity in future space stations, vestibular disturbances (i.e., motion sickness and disorientation) would be a prime determinant of the minimum acceptable radius. The stimulus of the vestibular system in the absence of gravity in the Apollo and Skylab missions has been shown to produce a sequela of motion sickness of three to five days in some crewmen followed by a period of insensitivity to motion sickness in response to provocative tests.

\section{Physiological Limits}

Subjects without prior experience can usually tolerate rotation rates as large as $0.63 \mathrm{rad} / \mathrm{s}(6 \mathrm{r} / \mathrm{min})$ in any axis or combination of axes. Most. sullijerts cannot initially tolerate rotation rates in the region of 1.26 to $3: 14 \mathrm{rad} / \mathrm{s}$ $(12$ to $30 \mathrm{r} / \mathrm{min})$ and rapidly become sick and disoriented above $0.63 \mathrm{rad} / \mathrm{s}$ unless carefully prepared by a graduated program of exposure. On the other hand, rotation rates of $6.28 \mathrm{rad} / \mathrm{s}(60 \mathrm{r} / \mathrm{min})$ for as $10 \mathrm{ng}$ as 3 or 4 minutes around the $y$-axis ( $p i t c h$ ) and around the $z$-axis (spin) have been described by some subjects as being not only tolerable but pleasant. Intolerability becomes manifest again at approximately $84.4 \mathrm{rad} / \mathrm{s}(80 \mathrm{r} / \mathrm{min})$ in the pitch mode and at approximately 9.4 to $10.5 \mathrm{rad} / \mathrm{s}(90$ to $100 \mathrm{r} / \mathrm{min})$ in the spin mode. In the pitch axis, with the center of rotation at the heart level, symptoms of negative acceleration $\left(-G_{2-}\right.$ are demonstrated at. apprnximately 8.4 $\mathrm{rad} / \mathrm{s}(80 \mathrm{r} / \mathrm{min})$ and are tolerable for only a few seconds. Some effects of positive acceleration $\left(+G_{z}\right)$, namely numbness and pressure in the legs, are al so observed but develop slowly, with pain being evident at approximately 9.4 $\mathrm{rad} / \mathrm{s}(90 \mathrm{r} / \mathrm{min})$. No confusion or loss of consciousness is found, but, in some subjects, disorlentation, headache, nausea, or mental depression are noted for several minutes after a few minutes of exposure. With rotation in the spin mode, when the head and trunk are inclined forward out of the $z$-axis, rotation approaches tolerance 1 imits at $6.28 \mathrm{rad} / \mathrm{s}(90 \mathrm{r} / \mathrm{min})$. Except for unduly susceptible subjects, tolerance tends to improve with frequency of exposure. Long-duration runs in the pitch mode have been endured for as long as approximately 60 minutes at $0.63 \mathrm{rad} / \mathrm{s}(6 \mathrm{r} / \mathrm{min})$ in selected subjects. 
These extreme limits are not likely to be a consideration in design of spacecraft. They may set limits to survivability in contingency situations involving failure of spacecraft orientation control system.

In considering physiological limits to angular acceleration with long-radius components (such as high-speed aircraft turns), it is appropriate to use the acceleration 1 imlts defined for 1 inear accelerations.

Interacting Environmental Parameters

The most significant interacting variable is the presence or absence of gravitational forces, particularly where the vestibular effects of radial acceleration are considered. Those environmental parameters previously mentioned. which interact with linear acceleration al so interact with radial acceleration.

Effect of Individual Variation

The space motion sickness syndrome that was noted in the Apollo and Skylab flights did not occur in all crewmen. 'Susceptibility of a crewman to motion sickness produced by provocative tests in one-g apparently had no corollary in weightlessness.

Research Needed to Further. Define Spacecraft Limits

Research is needed to define the causative mechanism of the motion sickness syndrome under zero-g conditions and to establi.sh preventive and/or ameliorative measures. Research is needed to define the effect of various durations of zero-g exposure on subsequent tolerance to angular accelerations in all axes.

\section{EFFECTS OF OTHER FACTORS}

Space workers may experience other potentially harmful effects other than the weightlessness of space or acceleration. These include habitat environments, 1 ife support systems in the habitat and work areas, health care, work areas hazards, and al tered biorhythms and diurnal.cycles. 
Habitat Environments

The various environments of the habitat area can present a broad spectrum of potentially adverse physiological or psychological effects. These potentially adverse environments influence habitat design or operational approaches at the cost of optimizing conditions for the space worker's well-being and almost always result in maximum costs and weight penalties. Many trade studies will be necessary to derive final habitat design of suitable environmental ranges. Elements of habitat environments include:

- Atmospheric compositions and pressures

o Temperature and humidity

o Noise and vibration

o Light.

- Odor

- Bacteria and toxic elements

- Circadian rhythm disruption

- Particulates (ingestibles and inhalation)

o Ionizing radiation (not treated in this document)

\section{Life Support Systems in Habitat and Work Areas}

To accomodate to the space worker's daily physiological and psychological health, safety and general well-being, the following items must be considered.

Food and Nutritition

Hygiene

Rest and recreation

Privacy

Clothing

[ntertainment
Water (pntahle, rleansing, industrial)

sleep

Exercise

Waste and trash management

Architectural design (space and layout)

\section{Health Care System}

An efficacious space Heal th Care System will provide for prevention and treatment of medical contingencies, trained medical personnel, and jrojer liedications and equipment. The elements of the Heal th Care System will include: 
Prevention: Selection of heal thy workers, periodic multiphasic screening, maintenance of health trend analyses, training and indoctrination of the space worker in important facets of space health, physical fitness programs, etc.

Treatment: Protocols for probable routine or emergency medical contingencies, and medical personnel - (paramedics, physician's assistants, physicians, and specialists consultants).

Medications and Equipment: Ready supplies of medication for known space complaints (motion sickness), contingency medications for common, ground-based complaints (toothache, headache, etc.) and drugs for emergency procedures. Equipment for monitoring day-to-day general heal th of the space workers as well as equipment to rescue, stabilize, transport and hospitalize a space worker in trouble.

\section{Work Area Hazards}

Construction will present many hazards. Workers will be exposed to heated surfaces, high electrical charges, mechanical dangers, brilliant light and complete darkness. Lack of references may present difficulties in judging distances and direction.

\section{Altered Biorhythms and Diurnal Cycles}

Space workers will be subject to several types of altered rhythms - from cellular and glandular internal body rhythms to daily habit routines. Some of these altered rhythms may be consequential enough to warrant identification and analysis, to determine their contribution to physiological or psychological probleils, arid to treat or correct. 


\section{AMELIORATION OF POTENTIALLY ADVERSE EFFECTS}

The physical and social world of a space worker is subject to many dramatic al terations and without adequate preparation and conditioning, a worker may be physiologically or psychologically affected adversely. These adverse effects may be partially or totally prevented if appropriate preventive actions are taken. If adverse effects are experienced, the severity of duration of the effect may be reduced with appropriate treatment or corrective action.

These preventive or corrective actions will be discussed in this report briefly and in general terms.

\section{A. PREVENTIVE ACTIONS}

Preventive actions for amelioration of adverse effects include: selection, training and indoctrination of candidates, estimating and stimulating motivation, programming physical conditioning, and maintaining good living and working conditions.

\section{Selection}

Satellite Power System workers will be selected for long-term assignments. The prime consideration will be the worker's capability for maximum productivity over a five-year carepr span. To obtain maximum productivity a space wurkcr must be in youd phystcal condition, be resilient and adaptable to changing and stressfur conditions, dedicated and purposeful in professional endeavors, and intelligent enough to understand not only the job requirements but the actions that must be taken to remain heal thy in space. The exact.criteria for selecting space workers and effertive means for tcsting potential workers for the desired characteristics must be developed.

Training and Indoctrination

Data from past manned space missions show that extensive training and thorough indoctrination are strong contributing factors to adaptation in the space environment. Astronauts reported the importance of training which enabled them to continue their duties even though they were suffering from malaise of vestibular origin. Proper indoctrination in the importance of fond, exercise, 
hygiene and other heal th sustaining regimens were responsible for minimizing potentially adverse physiological effects of the space missions.

Space workers of the future will require extensive training and indoctrination prior to their initial space filight and sustained training and indoctrination throughout their career. The nature and extent of this effort must be defined and suitable programs developed prior to the early. SPS missions; the STS and SOC programs of the 1980's will provide this early opportunity.

\section{Motivation}

A five year career as an SPS worker will place severe physiological and psychological stresses on the space worker, his or her family or associates. These stresses can lead to a very high personnel turnover.

Past experiences with various programs involving long-term assignments to remote and stressful environments have shown that good training and high salaries are not sufficient to maintain a steady work force. For example, off shore drilling companies are experiencing a 100\% annual turnover in personnel who are extensively and expensively trained and highly paid. These companies are desperately seeking better methods for selecting, preparing and sustaining a dependable work force.

In contrast, the Skylab, Tektite, and our nuclear submarine programs found their crews to be highly motivated and productive.

It is hoped that carcful studies of the effects of repeated missions for the STS crews and long duration ( 90 day) missions for the SOC crews will provide the answers for keeping SPS workers motivated and serving during an effective five year space career.

\section{Physical Conditioning}

Malntenarice of the spacc worker's physical condition is a significant factor in the amelioration of adverse effects of the space environments. A good physical condition requires regimens of adequate nutrition, exercise, rest and hygiene coupled with an enticing food system, enjoyable recreation, and psychological support. 
These requirements must be met between missions as well as during space flight and must be tailored to the needs of the individual. These needs will be dependent upon the character of the space worker, the quantity, quality and type of work to be done, and the levels of environmental stress involved.

The needs of U.S. astronauts and Soviet Union cosmonauts have been studied extensively at NASA. Al though the knowledge derived from these past missions is extensive there is a great deal to be learned about the needs for the individuals we may expect to employ in the SPS program.

Some countermeasures, devices and exercises designed to maintain musculoskeletal and cardiac condition in space, and to currect for reduced cardiac output upon reentry are 1 isted here.

Lower Body Negative Pressure Device (LBNP) - LBNP is the application of a partial vacuum to the body from the waist downward. It increases the volume of the legs temporarily, stresses the cardiovascular system and its controls, and may provide for maintenance of tonus in vasculature of the legs.

Gradient Positive pressure - Gradient positive pressure is the concept, of applying pressure to the lower half of the body during the: dynamic force of reentry and after recovery to prevent undue shift of body fluids as a result of vchicle accelerdtions and gravity. The pressure is applied in gradient fastion with the greatest. pressures in the regions farthest from the heart.

A gradient positive pressure device, worn to resist the dynamic force of reentry, is the G-suit or cardiovascular counter pressure garment. It can be used to prevent the pooling of fluids in the body below the level of the heart during the acceleration force of reentry and thus forestall possible orthostatic hypotension.

A G-suit is a pair of tight fitting trousers containing built in air bladders that are inflated or deflated by a manually operated air valve.

Venous occlusion cuffs - Venous occlusion cuffs are blood pressure cuffs that, when rhythmically inflated and deflated, interfere with return of venous blood 
to the heart. They may be used to stimulate the development of tonus in vasculature of the lower limbs.

Positive pressure breathing - Positive pressure breathing (PPB) is the application of a breathing system which pressurizes the air being inhaled or exhaled. By pressurizing the chest, it deters venous return to the heart, engorges veins, stresses the cardiovascular system and its controls, and is used to stimulate the development of tonus in vasculature.

Valsalva maneuver - The Valsalva maneuver is a method of pressurizing the chest by closing the glottis or obstructing the nostrils while attempting to exhale. Its effects are similar to those of positive pressure breathing.

Bone stress - Bone stress is achieved by using skeletal loading devices to forestall the effects of disuse in weightlessness. Several forms were tested, but in long-term bed rest studies (up to 17 weeks) no significant protection was afforded to the problem of bone loss.

Double trampoline - A double trampoline is a device composed of two trampoline heads between which a human can oscillate and receive sensory impacts which mimic the effects of gravitational acceleration on susceptible systems, including the cardiovascular system. (No studies yet conducted.)

Tumbling - Tumbling routines can be devised to simulate gravitational accelerations to members (arms and legs) at a distance form the body's center of gravity. (No studies yet conducted.)

Electrical stimulation of muscles - Electrical stimulation of muscles has been proposed to exercise muscles in weightlessness in order to prevent disuse atrophy and to provide skeletal stress. (No studies yet conducted.)

Exercise - Exercise coupled with another stressor (LBNP, cuffs, PPB or bone stress) has been proposed to produce effects that would be difficult to achieve singly in weightlesșness. Particular reference is made to coupling exercise with a means of producing a simulated gravitational effect on cardiovascular or skeletal systems while providing muscular exercise. To 
date, all studies have not afforded protection but the pregoing combination has not as yet been tested.

Hypoxia - Hypoxia is a powerful cardiovascular, respiratory and neurohumoral stressor which causes shifts in the electrolyte and acid-base balance and may counter the acidosis believed to occur in weightlessness. It may ameliorate disuse phenomena such as demineralization, but even so, it is doubtful that long periods of hypoxia would be feasible.

Medication - Medication has been proposed to counteract or ameliorate weightless responses, e.g., hormone therapy to curtail loss of potassium and calcium.

Centrifugation Centrifugation is a technique for supplying arlificial gravity to a space vehicle and as a stressor in studies of acceleration physiology.

The SOC program is expected to yield significant information in this area of interest.

\section{Living and Working Conditions}

The physical and psychological well being of the SPS space worker will be affected by environments that are controllable as well as those that are inherent in space flight. The living and working conditions of the space worker will need careful consideration if the long and repeated missions are to be made acceptable. Some of the more obvious controllable element.s are:

- Lighting

- Temperature

o Humidity

- Breathing Environment (pressures and constituent gases)

o Noise

- Toxic and Noxious Elements

- Architecture (space drld layuut)

- Clothing

- Social and Management Structure 


\section{B. TREATMENT AND CURATIVE ACTIONS}

We must expect that with many hundreds of space workers involved, some will be adversely affected by the environments of the space missions. The adverse effects may vary in severity and duration. Curative action will be taken to exclude the cause and treatment will be administered to el iminate the effect. Some possible actions are discussed briefly below.

\section{Task Reassignment or Schedule Modifications}

The assigned work task of a person may be such that undue mental or physical stress results. A change of task may provide more heal thful conditions by changing neurologic, metabolic, environmental, etc., stresses.

Schedule modifications may improve conditions affecting eating, sleeping and social activities.

\section{Physical Conditioning}

The physical conditioning needs will vary with individuals and may change with time. Where a worker is getting improper diet, rest, exercise, etc., some adverse effects are probable and the physical conditioning regimen must be adjusted to correct them. Frequently this may be a matter of personal discipline. If the worker is deliberately neglecting a healthful regimen, closer supervision may be involved in the corrective action.

\section{Medical Treatment}

In situations where the worker has experienced a medical contingency involving illness or injury due to any cause there must be adequate medical treatilent available to stablize or heal the victim.

Medical capability will include diagnostic and treatment systems with suitable support for rescue, transportation, and communications. These. systems have been extensively defined, analyzed and evaluated in several developmental programs and tested during past manned space missions. 
Altered Living Conditions

If some element of the space worker's living conditions causes an adverse effect or if a change in living conditions is held necessary during the treatment peiod, then these conditions can be modified. Such changes could range from moving the individual to a quiet area or to complete isolation. 
VI. RESEARCH PLAN

\section{A. GENERAL}

The SOW, paragraph 5.1.2 Research P1 an Preparation, requests that NASA prepare a research plan addressing the uncertainties in the knowledge regarding the health and safety effects of the zero gravity environment and acceleration/deceleration and which, if carried out, will make future assessments more reliable and/or help to el iminate or ameliorate adverse heal th effects.

In responding to this SOW task, NASA again has taken the 1 iberty of treating all the space environments except the radiation enviroment. We have also assumed that the period of time covered by the plan will extend from the present until just prior to the first SPS space mission (approximately 20 years).

It is anticipated that NASA-JSC will be conducting two major space programs in the 1980's and early 1990's - the Shuttle/Spacelab Space Research and the Space Operations Center. Our Life Sciences organizations will be conducting. research in support of these programs. This research can be designed to yield information needed to identify potential adverse effects of the SPS-type space operations and suitable countermeasures.

Rather than present the research plan as a formalized planning document, we have chosen to provide information relating to the types of research that NASA scientists feel should be accomplished and indicate when the results of this research will be availahle. We have also provided information on which institutions and agencies are currently involved in the "NASA" research program and how DOE may become involved.

To describe the research plan to qualify humans for long periods in space as merely a NASA plan is an injustice because the people who aid in planning and conducting the research and validation are not exclusively NASA personnel; this program is international in scope. 
The SPS program will introduce to NASA a new opportunity to extend and expand currently planned research. It will also provide an opportunity for DOE to participate in the planning, conduct and administration of the life sciences research activities.

\section{B. RESEARCH AREAS}

During the next few years NASA-JSC will be involved in research designed to support the general objectives of Life Sciences:

- To determine effects of space environment on 1 ife systems.

- To gain greater understanding of 1 ife processes and systems.

o To extend crew health care capabilities for space utilization and exploration.

o To develop improved life support and protection systems for people working and living in space.

o To develop crew operations and equipment design to enhance crew/spacesystem integration.

o To develop processes that exploit the advantages of space for bioprocessing.

o To determine advantages of space to help support clinical research on Earth, and

o To synthesize space technolngy to health care for peuple on Farth.

This research will be conducted in various laboratories thoughout the natinn and in space aboard the Shuttle/Spacelab.

The research will be directed to support general objectives of Life Sciences as well as the sperific noeds of NASA spact programs. There are three specific programs that have some probability of being funded in this decade - the STS, SOC and SPS programs.

Bioresearch done for any one program will often benefit all programs, and for this reason we have chosen to include a general description of the potential research which may support the needs of the SPS program. 


\section{Currently On-Going Research}

NASA-JSC is currently involved in over 100 ground-based experimental studies. These studies relate to medical and clinical protocols, space physiology, 1 ife support systems, extravehicular systems, heal th maintenance and crew selec-. tion. Documented records of these on-going studies are available at JSC. Some studies have been active for several years and others have been recently initiated to cover new research areas.

A partial listing of the major groups of experiments is shown in table VI-1. These Research and Technology Objectives and Plans (RTOP) may consist of from 2 to 15 individual studies. An example of one group is shown in table VI-2.

\section{Shuttle/Spacelab Space Experiments}

During the Shuttle/Spacelab missions, it is anticipated that approximately 100 Life Sciences experiments will be flown to explore the physiological/psychological effects of the space environment. Another 20 to 30 experiments will be performed to support the definition of requirements for heal th care, life support and protective systems (LS/LP) or habitability systems.

The Shuttle/Spacelab missions will be 7-day or 30-day missions and consequently will not provide an opportunity to perform experiments on long duration space exposure. Life Sciences at JSC has a responsibility for crew health maintenance and for assuring that crewmembers are selected to meet certain medical selection criteria. It is anticipated that some observations regarding physiological problems and fatigue build-up of crewmembers may provide information useful in the selection, training and indoctrination of future space workers. 
TABLE VI-1. CURRENT RESEARCH

RTOP GROUP NO.

199-10-11

199-10-21

199-10-31

199-10-41

$199-20-11$

$199-20-21$

199-20-31

$199-20-51$

199-20-61

199-20-71

$199=20-91$

199-60-11

$199-60-21$

$199-60-31$

$199-60-41$

199-60-71

199-70-11
TITLE

Operational Laboratory Support

Medical Selection Criteria

Crew Heal th Maintenance

Systems Habitability Verification

Cardiovascular Deconditioning

Space Motion Sickenss

Bone/Muscle Alterations (See table VI-2).

Blood Al terations

Fluid and Electrolyte Changes

Radiation Effects and Protection

General Research

Life Support Systems

Extravehicul ar Systems

Nutritional Requirement.s

Food Production

Man-Machine Systems

Program Definition 
TYPICAL RTOP: 199-20-31 Bone/Muscle Alterations

\begin{tabular}{|c|c|}
\hline Code & Task Title \\
\hline 01 & Long Term Bed Rest \\
\hline 03 & Calcium and Bone Metabolism \\
\hline 04 & Musculoskeletal Deterioration \\
\hline 05 & Muscle Disuse Atrophy \\
\hline 07 & Skeletal Muscle Disuse Atrophy \\
\hline 08 & Systems/Calcium Me tabolism \\
\hline 09 & Bone Implant/Growth \\
\hline 10 & Bone Density/Tomography \\
\hline 11 & Calcium Metabolism Parameters \\
\hline 12 & Vitamin D Metabol ism \\
\hline 13 & Vitamin $\mathrm{D} /$ Calcitonin/Parahormor \\
\hline
\end{tabular}

Research in Support of the SOC Program

In support of the OSC program, Life Sciences will conduct a number of studies. relating to the systems definition of heal th care, LS/LP, and habitability systems. These SOC systems could serve as demonstration models to help formulate SPS design and operational approaches.

To illustrate the type of research involved in our planning, we have included a list of SOC research proposals submitted by NASA scientists. These are shown in table VI-3. Table VI-4 relates the research proposal to a particular biosystem or entity. 
Brief forms of each proposal will be reviewed and those selected prioritized as a next step in the formulation of an SOC support plan. Further information about proposals listed are available through the Space and Life Sciences Directorate, JSC.

Of equal importance is the experience to be gained from the SOC operational activities. This program will involve from 4 to 16 space workers living in modular 4-man habitats for periods of 90 days. The space activities, work schedules and mission cycles will be similar to those described in the SPS reference report. For the first time crewmembers will be making repeated missions into space and working at "routine" jobs in the space environments.' The long term and accumulative effects of repeated trips into space on the crewmembers and their families (or social contacts) will be explored. Because nf crew size and length uf mission the studies will be 1 imited on the STS program and more extensive on the SOC program.

\section{TABLE VI-3. SUGGESTED SOC RESEARCH PROPOSALS}

1. To advance biochemistry studies (electrolyte levels and levels of steroid hormones).

2. To study physiological/biochemical aspects of bone demineralization (biochemical data; animal data; remedy develnpment).

3. To study inflight cliniral microbiology capabllity (contamination contrọl: clinical 1 ab; sy'stem impruvements).

4. To study inflight clinical/resedrch capability /health monitoring; broad banded).

5. To study infectious disease control (study populations, adjust balances).

6. To study SOC atmospheric monitoring (toxicology trace gas anaiysis).

7. To determine nutrient requirements under weightless conditions (develop requirements through surrogates).

8. To adapt recommended dietary allowances to long-duration space flight (determine nutritional requirements vis-a-vis stress, through humans and surrogates).

9. To study immune competence during long-duration space flight (determine immune responses of 500 subjects on 90 -day flight). 
10. To study erythrokinetics during long-duration space flight missions (examine changes in red cell replacement in space flight; kinetics, mechanisms, chronic reexposure).

11. To study and develop methods to predict and treat myocardial infraction, particularly in space where fluid shifts, volume, endocrine, and excretory changes occur.

12. To $\mathrm{plan}$ and execute countermeasure development for bone demineralization.

13. To determine diagnostic and research equipment and radio-pharmaceuticals for inflight utilization; perform modifications for space use.

14. To prevent and correct cumulative atrophic effects on muscle.

15. To study particulate handling by pulmonary system.

16. To assess clothing considerations in a large space habitat (clothing selection, laundering and cleaningl.

17. To study safety considerations in the space operations center regarding loss of pressure (pressure suits, emergency pressure system in vehicles, transfer sphere, pressure haven).

18. To develop non-invasive techniques to monitor subclinical bubbles in the tissues of space workers (develop instrumentation for research in gas embolus formation [bends]).

19. To develop and utilize a quantitative index of bends susceptibility (consider and evaluate susceptibility factors - age, exerise, body fat in bends).

20. To determine limits of repetitive decompressions in space workers (evaluate 1 imits of successive exposures).

21. To determine cabin and suit pressures for space operations center (develop cabin and suit pressures for operational and emergency use).

22. To determine humidity control in large spacecraft (determine engineering penalties of different options).

23. To determine temperature control in a large spacecraft (study of costs and benefits of various strategies).

24. To develop a proposal for a health maintenance facility for the Space Operations Center (develop a space clinic).

25. To study the effect of prolonged exposure to weightlessness on sensory system functions (effect on sensory system function; adaptation, and readaptation from one-g to weightless). 


\section{TABLE VI-3 (Continued)}

26. To study the gravity receptor alterations during prolonged exposure to weightlessness (determine effects of long-term exposure to weightlessness such as morphological or functional alterations, which may or may not be appropriate for one-g; use humans and surrogates).

27. To study space motion sickness (develop predictors, countermeasures and operational procedures to minimize sickness effects).

28. To determine an advanced feeding system (define food system for SOC).

29. To determine reclaimed water quality requirements (develop standards for potable water; develop standards for non-potable water for hygiene; develop water quality monitoring devices).

30. To study and determine clothing/bedding provision (determine method or recyriling ur disposal).

31. To study and determine solid waste/refuse disposal (identify and quantitate material; determine means of disposal).

32. To determine advanced metabolic waste management (develop a multi-use system).

33. To study metabolic waste sampling and monitoring (devise system for sampling human waste for scientific and clinial use).

34. To study personal hygiene (identify requirements for hygiene and develop equipment).

35. To study housekeeping methods (evaluate provisions for housekeeping and sanitation for SnC).

36. To provide for envirnnmental control systems (devclop hardware to cluse water and atmospheric loops).

37. To analyze volatile organic contaminants in the spacelab atmosphere (collect air samples and monitor spills).

38. To study inflight analysis of aqueous samples using the miniature fast analyzer (to qualify a laboratory chemical analyzer in zero-g to support research and clinical requirements).

39. To study body fluid and electrolyte loss during early space flight (examine fluid compartments and measure content of samples to chart circulatory and renal adaptation to zero-g).

40. To determine the effects of null gravity on the effectiveness of nitrogen washout (conduct nitrogen washout trials in null gravity prior to EVA's). 
41. To study the effect of zero-g on sweat (quantitate sweat rates, evaporation dynamics in zero-g).

42. To study basal metabolism. in zero-g (measure effect of zero-g on metabolism and on postural muscles).

43. To study cell separations under microgravity conditions (space experiment to isolate kidney cells capable of producing urokinase).

44. To study tissue culture growth/fermentation in low-g (space environment where gravity-induced floating or sedimentation are reduced and culturing is optimized).

45. To study cell to cell interactions and biosynthesis dynamics in microgravity (space experiment to study cell physiology especially biosynthesis in zero-g).

46. To study laboratory animal for depression of CNS function produced by the combination of zero-g stresses and the intake of low levels of chemical compounds (in-flight toxicology to quantitate multistress and reevaluate space flight criteria [tolerances]).

47. To study coronary artery perfusion and systemic blood flow distribution (space experiment to quantify myocardial perfusion and systemic flow by radioisotopes).

48. To study pulmonary ventilation/perfusion and thoracic blood volume alterations in zero-g (space experiment to measure respiratory parameters in the presence of fluid shifts to the thorax).

49. To study in-flight saline ingestion as a countermeasure for reeexposure to normal gravity (space experiment to forestall symptoms or orthostatic intolerance in the presence of reduced blood volume by supplying physiologically-acceptable fluid upon recovery).

50. To study electromechanical cardiac activity (monitoring of cardiac phenomena in flight for clinical and research use).

51. To determine aerobic and muscular strength exercise requirements for spaceflights (develop exercises to enhance muscle strength and aerobic capacity and to uplift or maintain physical work capacity and physical conditioning as well as to promote crew health. 
52. To study physical performance in the space station (design countermeasures for reduced human physical performance, especially life support equipment, work stations, stabilization devices, locomotion aids, and exercise devices).

Research in Support of the SPS Program

Much of the biological and biosystems research scheduled for SOC will be applicable to SPS. There are, however, several characteristics of the SPS program that will require research directed specifically to SPS.

These features include:

- A large number of people - hundreds in space simul taneously,

- A large variety of tasks,

- $\Lambda$ large number of female worker's,

- Repeated long duration missions over a five year career span, and

0 Workers in GEO and LEO habitats and work area.

The significance of these unique features is that life support, protective, habitability and heal th care systems developed for previous programs would require scaling up or major redesign/replacement will a new system concept. In addition, the operational environments might introduce new psychological and sociological situations that may impact the worker and his family and earth-based associates. These projected situations will introduce new areas of research for NASA.

\section{SCHEDULE}

A schedule to provide information relating to the health and safety of SPS space workers has been formulated. Consideration is given to the "need" date for finalizing SPS workers' schedules (about 1995) and the currently anticipated manned space program preceding or concurrent with the SPS space missions. This schedule is shown in figure vi-1.

The period between now and the date when final SPS decisions will be made for such items as mission stay time, number of shifts, work schedules, and groundbased time between missions is currently estimated to be about 20 years. 
There will be a number of milestones during that time period when NASA will be able to provide supplemental information for making the decisions involving SPS workers' health and safety. These milestones are indicated in figure VI-1. A brief summary of the information now available at each milestone is outlined below. 


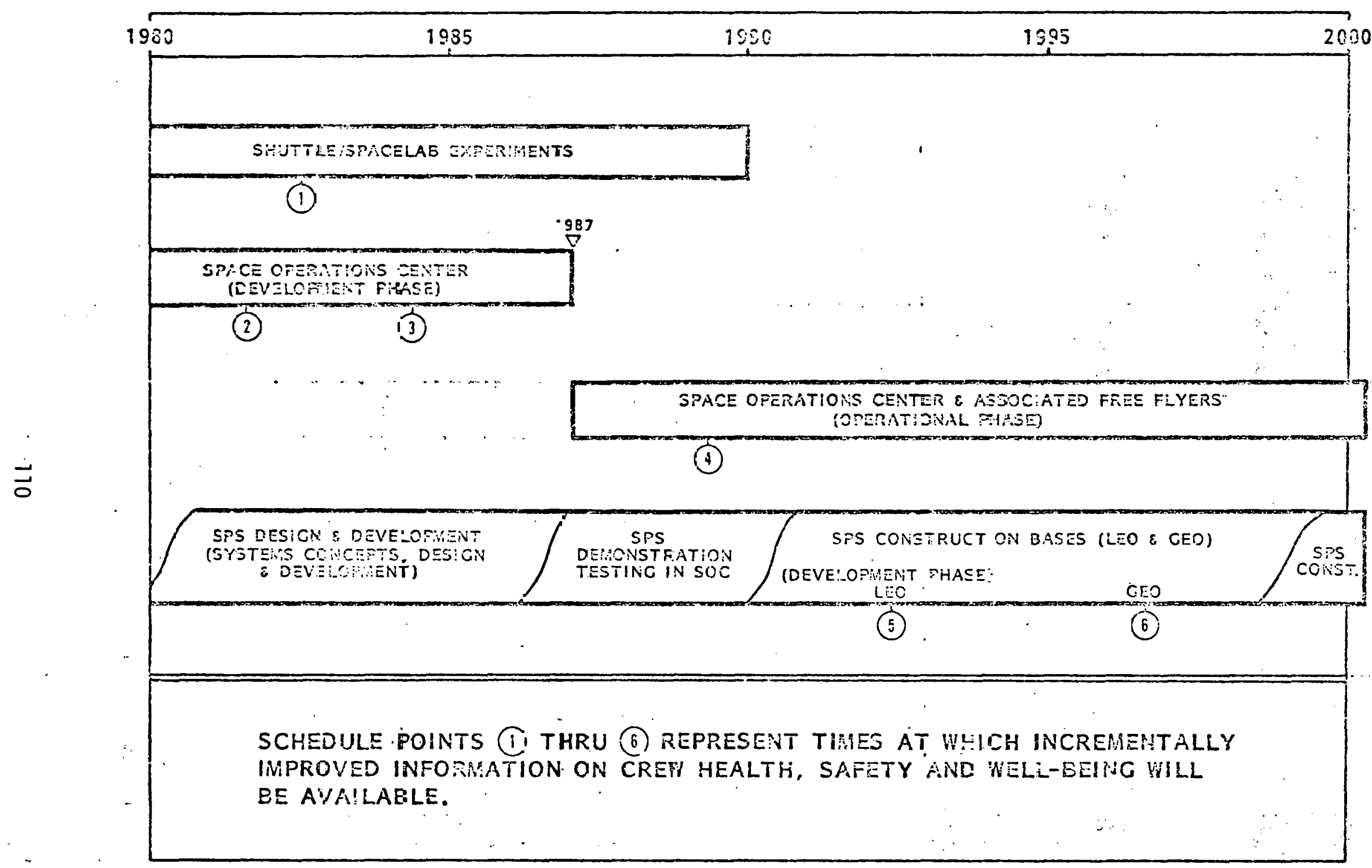

Figure VI-1. Comparative schedLles for the Shuttle/Space]ab, SOC, and SPS programs. 
1. After the first year of Shuttle missions, some crewmembers will have made repeated missions in LEO. These mission experiences will provide information regarding the trends in physiological and physchological responses of the crewmembers, and their families to this new life style.

2. As preparations for constructing a SOC get underway, extensive gound-based testing, crew training, and multiple mission simulations (demonstrations) will be conducted. Extensive information relating to crew health, safety and well-being, and to their relatives will be provided. In addition, this information is expected to indicate the type of life support and protective systems needed to enhance the morale and to provide living comfort for the space workers. It is during this period that many of the concepts of crew scheduling will evolve.

The gound-based training and mission simulations will duplicate the operational aspects of both flight and ground operations. It will al so serve to highlight potential problem areas in the hardware system, the operational procedures and the human performance of flight and ground crews.

3. With construction of the SOC progressing during several mission periods ( 9 months to one year), NASA will again be in a position to offer a significant amount of additional information relative to the crew schedules, the physiological/phychological health and safety of the crew, morale factors, and crew-related systems design and operational approaches for SPS habitat and work stations. During this period the cremmembers and their families will have experienced all phases of premission, mission and intermission activities, and the repeated experiences of adjustment.

The experience of mission repetition will enable NASA to understand the cumulative effects of the zero-g, one-g, and the transitional phases relating to job effectiveness, worker and family morale, and the physiological/psychological condition of the crewmembers. 
Additional information relating to working conditions, habitation suitability, number and type of medical contingencies, social structure tendencies, group dynamics, etc., will become available.

4. During SOC operations, NASA will continue to accumulate knowledge and experience while working with additional crewmembers, a greater variety of skills and intellectual levels, different social and organizational structures, and improved support systems, habitat configurations, operational procedures, etc.

5 \& 6. As the time approaches to send large numbers of workers into spacc to build the SPS construction bases, NASA W111 have gained much experience in preventing or correcting any adverse effects of the space environment on space workers. In addition, they will have learned much about maintaining high work effectiveness through worker selection, training and motivation. Increasing numbers of space workers will be required as the SPS construction bases in LEO and GEO develop. Increased crew reponses to the space environment, working conditions and crew support systems will permit NASA to make progressive evaluations based on the increased numbers, personalities and skills represented. 


\section{REFERENCES}

1 Thornton, William E., and John A. Rummel. Muscular Deconditioning and Its Prevention in Space Flight. In Biomedical Results from Skylab, edited by R. S. Johnston and L. F. Dietlein. NASA SP-377, pp 191-197. NASA, Wash. D.C., 1977.

2 Whedon, Donald, G., et al. Mineral and Nitrogen Metabolic Studies Experiment M071. op. cit.: pp 164-174.

3 Vogel, J. M., et a1. Bone Mineral Measurement, Experiment M087. op. cit:: pp 183-190.

4 Sawin, Charles F., et al. Pulmonary Function Evaluation During and Following Skylab Space Flights. op. cit.: pp 388-394.

5 Michel, Edward L., et al. Results of Skylab Medical Experiment M171. op. cit.: pp 372-387.

6 Henry, W. L., et al. Effect of Prolonged Spaceflight on Cardiac Function and Dimensions. op. cit.: pp 366-371.

7 Hoffler, G. W., et al. Vectorcardiographic Results from Skylab Medical Experiment M092: Lower Body Negative Pressure. op. cit.: pp 313-323.

8 Johnson, R. L., et al. Lower Body Negative Pressure: Third Manned Skylab Mission. op. cit.: pp 284-312.

9 Smith, R. L., et al. Vectorcardiographic Changes During Extended Space Flight: Observations at Rest and During Exercise. op. cit.; pp 339-350.

10 Bergman, S. A., et al. Evaluation of the Electro-Mechanical Properties of the Cardiovascular System After Prolonged Weightlessness. op. cit.: pp 351-365. 
11 Nicogossian, A. E., et al. Determination of Cardiac Size From Chest Roentgenograms Following Skylab Missions. op. cit.: pp 400-405.

12 Thornton, W. E., and G. W. Hoffler. Hemodynamic Studies of the Legs Under Weightlessness. op. cit.: pp 324-329.

13 Johnson, P. C., et al. Blood Volume Changes. op. cit.: pp 235-241.

14 Kimzey, S. L., Hematology and Immunology Studies, op. cit.: pp 249-282.

15 Mengel, C. E., Red Cell Metabolism Studies on Skylab. op. cit.: pp 242-248.

16 Nicogossian, A. E., et al. Crew Health; In The Apollo-Soyuz Test Project Medical Report, complled by A. E. Nicogossian. NASA SP-411, pp 11-24. NASA, Wash. D. C., 1977.

17 Smith, M. C., and R. Rapp. Food and Nutritions. op. cit.: pp 33-37.

18 Burchard, E. C., and A. E. Nicogossian. Achilles Tendon Reflex. op. oit.: pp $4 /=b \%$.

19 Martin, R. R., et a!. Polymorphonuclear Leucocyte Response. In Apollo-Soyuz Test Project Sumary Science Report. Vol. 1, NASA SP-412, pp 263-279. NASA, Wash. D. C., 1977.

20 Leach, C. S., and P. C. Rambaut. Biochemical Responses of the Skylab Crewmen: an Overview. In Biomedical Results from Skylab, edited by R. S. Johnston and 1. F. Dictlcin. NASA SP-377. pp 204-220. NASA, Wash. D.C., 1977.

21 LaFevers, E. V., et al. Spectral Analysis of Skeletal Muscle Changes Resulting from 59 Days of Weightlessness in Skylab 3. NASA TM X-58171, 1975. 
22 LaFevers, E. V., et al. Electromyographic Analysis of Skeletal Muscle. In The Apollo-Soyuz Test Project Medical Report, compiled by A. E. Nicogossian. NASA SP-411, pp 53-57. NASA, Wash. D.C., 1977.

23 Nicogossian, A. E., et al. Crew Heal th. op. cit.: pp 11-24.

24 Hoffler, G. W., et al. In-Flight Lower Limb Vol ume Measurement. op. cit.: pp 63-68.

25. Taylor, G. R. Medical Microbiological Analysis of U.S. Crewmembers. op. cit.: pp 69-85.

26 Leach, C. S. Biochemistry and Endocrinology Results. op. cit.: pp 87-100.

27 Kimzey, S. L., and P. C. Johnson. Hematological and Immunological Studies. op. cit.: pp 101-118.

28 Brown, J. W. Crew Height Measurement. op. cit.: pp 119-121.

29 Taylor, G. R. Microbial Exchange. In Apollo-Soyuz Test Project Summary Science Report. Vol. I, NASA SP-412, pp 237-262. NASA, Wash. D.C., 1977.

30 Hordinsky, J. R. Skylab Crew health - Crew Surgeons' Reports. In Biomedical Results from Skylab, edited by R. S. Johnston and L. F. Dietlein. NASA SP-377, pp 30-34. NASA; Wash. D.C., 1977.

31 Kubis, J. F., et al. Task and Work Performance on Skylab Missions 2, 3 and 4. Time and Motion Study - Experiment M151. op. cit.: pp 136-154.

32 Baker, J., T., et al. Changes in the Achilles Tendon Reflexes Following Skylab Missions. op. cit.: pp 131-135. 
33 Taylor, G. R. Skylab Environmental and Crew Microbiology Studies. op. cit.: pp 55-63.

34 Homick, J. L., et al. Effects of Prolonged Exposure to Weightlessness on Postural Equilibrium. op. cit.: pp 104-112.

35 Frost, J. D., Jr., et al. Sleep Monitoring on Skylab. op. cit.: pp 113-125.

36 Miche1, E. L., et al. Results of Skylab Medical Experiment M171 Metabolic Activity. op. ci.t.; pp 372-387.

37 Criswe11, B. S., and Kathy Culb. Cellular Immune Response; Experiment Mn-031. In Apnitir-Srigikz Test Projoot Sumoiry science Report. Vo1. I, NASA SP-412, pp 257-262. NASA, Wash. D.C., 1977.

38 Kerwin, J. P. Skylab 2 Crew Observations and Summary. In Biomedical results from skytab, edited by R. S. Johnston and L. F. Dietlein. NASA SP-377, pp 27-34. NASA, Wash. D.C., 1977.

39 Gibson, E. G. Skylab 4 Crew Observations. op. cit.: pp 22-26.

40 Whittle, M. W., et al. Biostereometric Analysis of Body Form. op. wi.t.: in 198-202.

41 Thornton, W. E., et al. Anthropometric Changes and Fluid Shifts. op. cit.: pp 330-338.

42 Hawkins, W: Royce, and John F. Lieglschirld. Clinical Aspecte of Crew Health. In Biomedioal Rasul.ts of Apolzo. NASA SP-368, pp 43-81. NASA, Washington, D.C., 1975.

43 Ferguson, J.F., et al. Microbiological Investigations. op. ait.: pp $83-103$. 
44 Leach, C. S., et al. Endocrine, Electrolyte, and Fluid Volume Changes Associated with Apollo Missions. op. cit.: pp 163-184.

45 Alexander, W. C., et al. Clinical Biochemistry. op. cit.: pp 185-196.

46 Kimzey, S. L., and C. L. Fischer. Hematology and Immunology Studies. op. cit.: pp 197-226.

47 Hoffler, G. W., and R. L. Johnson. Apollo Flight Crew Cardiovascular Evaluations. op. cit.: pp 227-264.

48 Rumme1, J: A., et a1. Exercise Response. op. cit.: pp 265-275.

49 Rambaut, P. C., et al. Nutritional Studies. op. cit.: pp 277-302

50 Rambaut, R. C., et al. Skeletal Response. op. cit.: pp 303-322.

51. Homick, J. L., and E. F. Miller II. Apollo Flight Crew Vestibular Assessment. op. cit.: pp 323-340.

52 Anderson, M. Biospex: Biological Space Experiments, A Compendium of Life Sciences Experiments carried on U.S. Spcaecraft. J. A. Rummel and S. Deutsch, editors NASA TM 58217, NASA, Washington, D. C., 1979.

53 Pestov, I. D., and S. J. Gerathewohl. Weightlessness. In Foundations of Space Biology and Medicine. Vol. II Ecological and Physiological Bases of Space Biology and Medicine, pp 305-354. NASA, Wash., D.C., 1975.

54 Berry, C. A. Weightlessness. In Biastronautics Data Book. Second Edition, J. F. Parker and J. R. West, editors. NASA SP-3006, pp 349-415. NASA, Wash., D.C., 1973.

55 Sandler, H., and D. L. Winter. Physiological Responses of Women to Simulated Weightlessness. NASA SP-430. NASA, Wash., D.C., 1978. 
56 Dietlein, L. F. Skylab: A Beginning. In Biomedical Results from Skyzab, edited by R. S. Johnston and L. F. Dietlein. NASA SP-377, pp 408-418. NASA, Wash., D.C., 1977.

57 Smith, A. H. Principles of Gravitational Biology. In Foundations of Space Biology and Medicine. Vol.. II, Book I, Ecological and Physiological Bases of. Space Biology and Medicine. pp 129-162. NASA, Wash., D.C., 1975.

58 Graybiel, A. Angular Velocities, Angular Accelerations, and Coriol is Accelerations: op. cit.: pp 129-162.

by Waligora, J. M., Physlcal Furces Generating Acceleration, Vibration, and Impart. In the Physiological Basis for Spacecraft Environmental Limits. J. M. Waligora, Coordinator, NASA Ref. Pub1. 1045, pp 71-107. NASA, Wash., D.C., 1979.

60 Grounds, D. J. Weightlessness. op. cit.: pp 71-107.

61 Yuganov, Ye. M., and V. I. Kopanev. Physiology of the Sensory Sphere Under Spaceflight Conditions. In Foundations of Space Biology and medicine. Vol. II, Book II, Ecological and Physiological Bases of Space Biology and Medicine, pp 571-579. NASA, Wash., D.C., 1975.

62 DOE/ER-0023. Satellite Power System Reference System Report. October 1978.

63 Graybie1, A., et a1. Experiment M131. Human Vestibular.Function. In Biomedical Results from Skylab, edited by R. S. Johnston and L. F. Diellein. NASA SP-377, pp 76-103. NASA, Wash. D.C., 1977. 
APPENDIX A

ACRONYMS AND ABBREVIATIONS

ACTH Adenocorticotrophic hormone

ADH Antidiuretic hormone

AGARD Avisory Group for Aeronautical Research and Development

ASTP Apollo Soyuz Test Project

CNS Central Nervous System

DOE Department of Energy

EMG Electromyography

EVA Extravehicular activity

GEO Geosynchronous Earth Orbit

h (hr) hour (s)

JSC Lyndon B. Johnson Space Center

LBNP - Lower Body Negative Pressure

LDH Lactate dehydrogenase

LEO Low Earth Orbit

LS/LP : Life Support and Life Protection

NASA National Aeronautics and Space Administration

PPB Positive pressure breathing

$(\mathrm{r} / \mathrm{min})$ revolutions per minute

rpm

rad radian

REM : : Rapid eye movement

RNA $\cdot$ Ribonucleic acid

RTOP : Research and Technology Objectives and PI ans

s (sec) second (s) (time)

SDH Succinate dehydrogenase

SOC Space Operations Center

SOW Statement of Work

SPS Satellite Power System

STS : Space Transportation System

Zero-g zero gravity

(or $0-g$ )

NASA-JSC

119 QU.S. GOVERNMENT PRINTING OFFICE: $1981-341-060 / 358$ 


\section{United States}

Department of Energy

Washington, D.C. 20585

THIRD-CLASS MAIL.

POSTAGE \& FEES PAID:

U.S. DEPT. OF ENERGY

PERMIT NO. G 20

THIRD CLASS MAIE

Official Business

Penalty for Private Use, $\mathbf{\$ 3 0 0}$ 